\title{
AVALIAÇÃO CLÍNICA DO TEMPO DE PERMANÊNCIA DE UM SELANTE DE FOSSAS, CICATRÍCULAS E FISSURAS OCLUSAIS, SEM OU COM POSTERIOR APLICAÇÃO TÓPICA DE FLÚOR
}

CLAUDIA DE ALMEIDA PRADO E PICCINO SGAVIOLI

Dissertação apresentada à Faculdade de Odontologia de Bauru, da Universidade de São Paulo, como parte dos requisitos para obtenção do título de Mestre em Odontologia, Área de Dentística.

(Edição Revisada)

BAURU

2000 


\section{AVALIAÇÃO CLÍNICA DO TEMPO DE PERMANÊNCIA DE UM SELANTE DE FOSSAS, CICATRÍCULAS E FISSURAS OCLUSAIS, SEM OU COM POSTERIOR APLICAÇÃO TÓPICA DE FLÚOR}

CLAUDIA DE ALMEIDA PRADO E PICCINO SGAVIOLI

Dissertação apresentada à Faculdade de Odontologia de Bauru, da Universidade de São Paulo, como parte dos requisitos para obtenção do título de Mestre em Odontologia, Área de Dentística.

(Edição Revisada)

Orientador: Prof. Dr. José Mondelli 
Sgavioli, Claudia de Almeida Prado e Piccino

Sg17a Avaliação clínica do tempo de permanência de um selante de fossas, cicatrículas e fissuras oclusais, sem ou com posterior aplicação tópica de flúor - Bauru, 2000. 175p. :il.;30cm.

Dissertação (Mestrado) - Faculdade de Odontologia de Bauru. USP.

Orientado: Prof. Dr. José Mondelli

Autorizo, exclusivamente para fins acadêmicos e científicos, a reprodução total ou parcial desta dissertação, por processos fotocopiadores e outros meios eletrônicos.

Claudia de Almeida Prado e Piccino Sgavioli 
29 de maio de 1962

Jaú, SP

Filiação

1980-1983

1992

1993

1994

1995
Nascimento

Antonio Carlos Piccino

Maria das Graças de Almeida Prado e Piccino

Curso de Odontologia, na Faculdade de Odontologia de Bauru, da Universidade de São Paulo.

Professora nas Disciplinas de Dentística e Cariologia, no Curso de Odontologia da Universidade do Sagrado Coração, Bauru.

Coordenadora Técnica das Clínicas de Odontologia da Universidade do Sagrado Coração, Bauru.

Suplente de Chefia do Departamento de Odontologia da Universidade do Sagrado Coração, Bauru.

Curso de Pós-Graduação em Dentística, em nível de Mestrado, na Faculdade de Odontologia de Bauru, da Universidade de São Paulo, Bauru. 


\section{AgRAdECIMENTO A DEUS}

Oração para obter a Sabedoria:

"fazei-a, pois, descer do vosso Santo Céu e enviaia do trono de vossa glória. Para que, junto de mim, tome parte em meus trabalhos, e para que eu saiba o que Vos agrada". Sabedoria 9,10.

\section{Obrigada Deus, Pai de Nosso Senhor Jesus Cristo, que nos fez à sua imagem e semelhança e nos deu a sua mãe Maria como exemplo de mulher sábia.}




\section{AGRADECIMENTOS ESPECIAIS}

Ao meu esposo e companheiro Mirto Junior, pessoa muito importante, pelo amor e companheirismo sempre presentes nas nossas vidas.

Aos meus filhos Camila, Ana Cândida e Mirto Neto, razão de meu viver, pela compreensão e paciência com o meu tempo dedicado ao trabalho com a Odontologia. 
Ao meu pai, Prof. Dr. Antonio Carlos Piccino, pela sua capacidade profissional, toda ela voltada à Odontologia.

À minha mãe Gracita, pelo amor que reina em nossa família e pela exigência da verdade e uma atitude de serviço conformes ao ideal cristão.

Aos meus irmãos Antonio Carlos e João Carlos, pelo apoio e incentivo ao meu trabalho, e à querida irmã Graziela, companheira diária no trabalho voltado ao enriquecimento de nossa profissão. 


\section{Ao Prof. Dr. José Mondelli, toda a minha admiração agradecida, pela orientação deste trabalho, e pelo exemplo de valorização e gosto pela pesquisa na Odontologia.}




\section{AgRAdeCIMENTOS}

À Irmã Marisabel Leite, sempre pronta a dar conta a quem lhe pede, da esperança que nela existe, com amabilidade e respeito, representando todas as irmãs Apóstolas do Sagrado Coração de Jesus que, com coração puro e espírito de firmeza, dirigem a Universidade do Sagrado Coração.

Ao Prof. Dr. Luiz Casati Alvares, com seu testemunho de seriedade e rigor, representando todos os meus colegas docentes do Curso de Odontologia da USC, pelo apoio e incentivo.

Às colegas professoras Lucirene Aparecida Domingues e Débora

Barroso Legramandi, colaboradoras no desenvolvimento do meu trabalho, meu agradecimento extensivo a todos os colegas docentes da área de Dentística do Curso de Odontologia da USC.

Às colegas professoras Regina Célia de Mello Fraga e Lia Almeida Prado de Araújo que, em conjunto com minha irmã Graziela de Almeida Prado Piccino Marafiotti, desenvolvem o trabalho cristão consciente para uma Odontologia em Saúde Coletiva.

A todos os funcionários da USC, em especial às senhoras Maria Geralda Leite Marcelino e Ana Maria Daher, pela estima e apoio ao meu trabalho.

Aos colegas da pós-graduação, em especial à professora Ester Grassi Pinto Ferreira, pela amizade e incentivo.

Aos docentes e funcionários da Faculdade de Odontologia de Bauru, da USP, pela acolhida e apoio; em especial, nesse momento, àqueles da Pós-graduação e do Departamento de Dentística.

Aos meus alunos, por serem motivo para a eterna busca do saber.

Aos pacientes, fim maior da procura constante do crescimento humano e profissional. 


\section{SUMÁRIO}

RESUMO

1 - INTRODUÇÃO _ — — —

2 - REVISTA DA LITERATURA ..._ — 10

2.1 AVALIAÇÃO DO TEMPO DE PERMANÊNCIA E EFETIVIDADE DO SELAMENTO OCLUSAL

2.2 ASSOCIAÇÃO DO FLÚOR TÓPICO À TÉCNICA DE SELAMENTO, COMO MÉTODO DE PREVENÇÃO DE CÁRIE

3 - PROPOSIÇÃO

4 - MATERIAIS E MÉTODOS

5 - RESULTADOS

6 - DISCUSSÃO

7 - CONCLUSÕES

REFERÊNCIAS BIBLIOGRÁFICAS 


\section{RESUMO}

O processo carioso nas superfícies oclusais se inicia muitas vezes pelo acúmulo de microrganismos e nutrientes dentro das fossas, fissuras e cicatrículas. Sabe-se que com a utilização de fluoretos topicamente a incidência de lesões cariosas está diminuindo, contudo a porcentagem de cáries nas superfícies oclusais continua alta. Foi realizado o estudo da po-ssibilidade da combinação dos efeitos do flúor e dos selantes de sulcos, fossas, cicatrículas e fissuras, verificando-se o grau de permanência do selante resinoso fotopolimerizável Fluroshield (Caulk/Dentsplay, Milford) em dois grupos experimentais após uma única aplicação; grupo A- aplicando selante e imediatamente após aplicação tópica de flúor gel, e grupo B- somente selante. A amostra foi composta por 60 crianças, com idade entre 8 e 15 anos, que possuíam 1os ou 20 s molares permanentes inferiores sem evidência radiográfica de cáries interproximal e/ou oclusal. Os dois grupos de dentes selados pertencentes ao estudo passaram por quatro avaliações: imediatamente e após uma semana, 6 e 12 meses. Através da análise estatística dos resultados, pelo teste de GOODMAN ${ }^{136}$, em nível de 5\% de significância, foi verificado que nas avaliações de 1 semana e 6 meses não houve diferença entre os dois grupos, já na de 12 meses houve predominância significante $(p<0,05)$ da presença total de selante no grupo $A$, com aplicação de tópica de flúor gel. Não houve presença de cárie oclusal e interproximal nos molares selados, durante os 12 meses de avaliação. A associação da aplicação tópica de fluoreto acidulado com o selante aumenta o grau de permanência deste último e determina uma diminuição na incidência de cáries proximais. O selante apresentou-se efetivo, com 100,0\% de permanência total e prevenção de cárie, depois de 1 ano, quando associado à posterior aplicação tópica de flúor. 


\section{1 - INTRODUÇÃO}

Evidências experimentais suportam o conceito de que microbiota e substrato adequado são pré-requisitos para a instalação da cárie dental, uma vez que já foi demonstrada a necessidade da bactéria oral e de um substrato local no aparecimento da doença (AXELSSON ${ }^{15}, 1978$; AXELSSON ${ }^{16}, 1981$; KRASSE ${ }^{191}$, 1988; NEWBRUN ${ }^{239}$, 1990; LOESCHE ${ }^{203}$, 1993; CAUFIELD ${ }^{68}$, 1993; ARAÚJO; FIGUEREDO², 1997).

No estudo da doença cárie, os fatores primários, sem os quais o processo não conseguiria se desenvolver, não são claramente distinguidos dos fatores secundários ou predisponentes, que por sua vez controlam o grau de progressão da doença.

Muitos destes fatores secundários, como a composição e fluxo da saliva, a higiene bucal e a exposição ao flúor, entre outros, podem aumentar ou diminuir a resistência do dente à cárie, a quantidade e a natureza da microbiota envolvida na instalação da doença e também a cariogenicidade do substrato local (KRASSE ${ }^{191}$, 1988; NEWBRUN ${ }^{240}$, 1992; BRATTHALL ${ }^{41}, 1992$; LOESCHE $^{203}$, 1993; CAUFIELD ${ }^{68}$, 1993; KAY ${ }^{180}$, 1996; KAY'19, 1998; GIBSON; WILLIANS $\left.{ }^{126}, 1999\right)$.

Apesar de grandes avanços nas técnicas preventivas e da possibilidade de paralisação de lesões cariosas, pode-se prever que a necessidade de confecção de restaurações ainda continuará por longo tempo. As técnicas restauradoras e os materiais restauradores utilizados ainda têm suas limitações com dificuldades a serem superadas e, como resultado de um tratamento restaurador inapropriado, muitos pacientes têm sido mutilados e expostos a um ciclo repetitivo de restaurações (SERRA ${ }^{296}$, 1997; VARSIO ${ }^{356}$, 1997).

Gradualmente os Cirurgiões-Dentistas estão substituindo a antiga filosofia restauradora por uma abordagem mais cautelosa no momento de decidir a indicação de tratamento (CARVALHO; MALTZ ${ }^{63}$ 1997; POWELL ${ }^{254}$, 1999). 
A anatomia das faces oclusais dos dentes posteriores, por possuírem muitos detalhes como sulcos, fossas, cicatrículas e fissuras têm maior suscetibilidade ao início de desmineralização (KONIG ${ }^{188}$, 1963; ROHR; MAKINSON; BURROW'289, 1991). Além disto, esses detalhes anatômicos dificultam o acesso, diminuindo a ação da saliva e do flúor, bem como da limpeza mecânica promovida pela escovação (KEMPER ${ }^{181}$, 1984; KEMPER ${ }^{182}$, 1988; NEWBRUN ${ }^{239}$, 1990; FERREIRA ZANDONÁ ${ }^{113}$ et al., 1998). Esta característica das superfícies oclusais tornam estas faces oito vezes mais suscetíveis ao desenvolvimento de cárie do que as demais (BACKER DIRKS $^{17}$, 1961; STAM ${ }^{319}$, 1984; RIPA; LESKE; VARMA ${ }^{275}$, 1988; STAM; KATZ $^{321}, 1993$; STAM $^{320}$, 1995).

A alta suscetibilidade destas áreas ao desenvolvimento de processos cariosos está diretamente relacionada com a morfologia das fissuras, que apresentam uma grande variação quanto à forma, sendo geralmente estreitas e tortuosas, com invaginações irregulares onde bactérias e restos alimentares são retidos mecanicamente (FUSUAYAMA; KUROSU ${ }^{121}$, 1964; MARTHALER; O'MULLANE; VRBIC ${ }^{215}$, 1996; GILLCRIST; VAUGHAN $\left.{ }^{128}, 1997\right)$.

As fissuras oclusais consistem de falhas profundas e estreitas na região dos sulcos, e se estendem pela espessura do esmalte oclusal (MENAKER ${ }^{224}$, 1984).

As faces oclusais representam $12,5 \%$ das superfícies dentais e, por serem tão suscetíveis, merecem receber uma proteção especial, uma vez que o flúor e a clorexidina não apresentam ação efetiva nessas regiões (BACKER DIRKS $^{17}$, 1961; LEWIS; HARGREAVES ${ }^{199}, 1975$; SWANGO; BRUNELLE ${ }^{336}$, 1983; WENDT; KOCK ${ }^{369}$, 1988).

Apesar da fluoretação da água poder resultar em redução de cáries nas faces oclusais e proximais, BACKER DIRKS ${ }^{18}, 1974$, sua ação não é tão efetiva nas faces oclusais, na áreas de fossas e fissuras, onde existe maior prevalência nas faces oclusais (RIPA $\left.{ }^{269}, 1980\right)$. Isto tem conduzido à busca constante de métodos preventivos para o controle dessa lesão (VERTUAN; MIRANDA $^{357}$, 1975; WENDT; KOCK ${ }^{369}$, 1988; CAVALCANTI ${ }^{69}$ et al., 1997).

Após a descoberta e confirmação da ação preventiva dos compostos que liberam o íon flúor sobre o comportamento da ocorrência da cárie dental, a conduta profissional tem sido redimensionada com objetivos de se prevenir esse sério problema bucal, VALSECKI; VERTUAN ${ }^{353}$, 1988. Porém, 
segundo GOURLEY ${ }^{138}$, 1975; ROCCA ${ }^{277}$ et al. 1979; BOHANNAN $^{30}$ et al., 1984, entre outros, a ação do flúor é dotada de limitações no processo preventivo à lesão de cárie, conferindo maiores benefícios às superfícies lisas que as oclusais.

Naquelas populações em que, graças à utilização generalizada de fluoretos, tem sido obtida uma redução drástica de incidência de cárie continua ainda a se verificar alguma atividade de cárie, principalmente as localizadas nas superfícies rugosas de fossas, cicatrículas e fissuras (JOHNSON $^{177}, 1988$; WALDMAN ${ }^{365}$, 1990). As fissuras definem, com efeito, áreas de permanência das bactérias cariogênicas e de nutrientes e, em relação às mesmas, não se verifica o efeito favorável da saliva e dos fluoretos em aplicação tópica (CARLOS; GITTELSOHNº, 1965; CARDOSO; ISSAO59, 1987; AMORIM; FIGUEIRÔA; LIRA ${ }^{8}$ 1997).

$\mathrm{Na}$ prática clínica da Odontologia a idéia de tratamento vem se modificando, com base no conhecimento científico onde se questiona, inclusive, a própria qualidade dos materiais restauradores empregados, as técnicas e cirurgias e mesmo a justificativa para a utilização de determinados procedimentos ( NAVARRO; CORTES ${ }^{237}, 1995$ ).

A necessidade de se evitar aquilo que se denomina "sobretratamento", isto é, a intervenção pela intervenção, sem uma base que a justifique, obriga o profissional a conhecer as alternativas de tratamento e suas conseqüências para a saúde do paciente e o estabelecimento de critérios bem definidos que irão nortear a decisão clínica (KRIGER $\left.{ }^{192}, 1997\right)$.

Em relação ao manejo da saúde das superfícies oclusais, principalmente dos sulcos, alguns autores, BROWNBILL; SETCOS ${ }^{47}$, 1990; CARVALHO; THYLSTRUP; EKSTRAND ${ }^{64}$, 1992; ELDERTON ${ }^{105}$, 1993; KIDD ${ }^{183}$, 1994, têm questionado as alternativas possíveis, analisando parâmetros que partem de uma visão cuidadosa de risco e atividade de doença, propondo intervenções que vão desde o tratamento não operativo até o estabelecimento de critérios para a definição de opções terapêuticas específicas.

Os tratamentos curativos das enfermidades bucais são preocupações de longa data dos profissionais de saúde, especificamente dos odontólogos, e modernamente a preocupação dos pesquisadores em busca de métodos e meios de prevenção e controle da cárie dentária tem sido uma constante $\left(\right.$ EDEN $\left.^{102}, 1976\right)$. 
Muitos métodos para reduzir o ataque da cárie nas superfícies oclusais têm sido investigados desde o início dos anos 20, como aqueles que objetivam a eliminação dos sulcos e fissuras; eles incluíram sua remoção e a colocação de restauração de amálgama ou o alargamento do defeito anatômico para garantir a fácil limpeza (HYATT ${ }^{167}$, 1923; BÖDECKER ${ }^{27} 1929$ ).

Agentes químicos como nitrato de prata (MILLER ${ }^{232}$ 1905; KLEIN; KNUTSON $^{184}$, 1942), cloreto de zinco e ferrocianeto de potássio (AST; BUSHEL; CHASE ${ }^{14}, 1950$ ), diamino fluoreto de prata (YAMAGA et $\mathrm{al}^{378}$. ., 1972) e cimento de cobre ( MILLER ${ }^{231}, 1951$ ), foram usados para obturar os sulcos e fissuras, mas com pouco sucesso clínico.

O êxito desses esforços para bloquear a instalação de lesão cariosa em sulcos, fossas, cicatrículas e fissuras foi alcançado através do selamento oclusal com um material resinoso capaz de se unir mecanicamente ao esmalte dental, o que foi possível graças à proposição de BUONOCORE ${ }^{51}$ que, em 1955, desenvolveu um método exclusivo de adesão mecânica da resina plástica ao esmalte dental previamente condicionado com ácido fosfórico.

Com a finalidade de melhorar a adesão de um material resinoso ao esmalte dental, BUONOCORE ${ }^{51}$, 1955, utilizou o condicionamento da superfície do esmalte com ácido fosfórico a $85 \%$ e ácido oxálico a $10 \%$ por 30 segundos, e constatou que o uso do ácido fosfórico para tratamento das superfícies de esmalte aumenta adesão em proporção maior do que a do ácido oxálico. Este condicionamento foi indicado como forma de tratamento das cicatrículas e fissuras dos dentes, visto que a utilização de ácidos aumenta a umectabilidade da superfície, melhorando a adesão das resinas com o esmalte quando se objetiva executar o selamento.

Visando obter um material com propriedades ideais, novas pesquisas foram realizadas. BOWEN ${ }^{31}$, em 1963, colaborou para o surgimento de um novo tipo de resina, com propriedades físicas e químicas melhoradas. Esta resina é a resultante da reação entre bisfenol A e o glicidil metacrilato BISGMA (HEROLD $\left.{ }^{156}, 1990\right)$. Uma nova era surgiu resultante dos trabalhos de $\mathrm{BOWEN}^{34}$.

A técnica empregada para a proteção das áreas retentivas nas faces oclusais é a aplicação de resina fluida nesse local, promovendo o selamento mecânico da região, como foi sugerido por CUETO e BUONOCORE ${ }^{79}$, há três 
décadas, e tem sido aceita ao longo do tempo por diversos autores e pela classe odontológica. $O$ selamento de fossas e fissuras começou a partir destes trabalhos a ganhar confiabilidade pelos profissionais da odontologia.

Em 1963 BUONOCORE ${ }^{52}$ afirma que o adesivo ideal seria aquele que: possibilitasse uma união duradoura, quer com o esmalte quer com a dentina; polimerizasse a uma temperatura próxima àquela do corpo humano, com pouca ou nenhuma contração, com resistência suficiente para suportar as cargas mastigatórias; tivesse coeficiente de expansão térmica linear idêntica à do dente; fosse inofensivo à polpa dental e aos tecidos bucais; fosse resistente à degradação no meio bucal.

Em 1967, uma primeira avaliação clínica dos resultados de um ano de selamento foi reportada por CUETO; BUONOCORE ${ }^{79}$. Este artigo foi um marco histórico; introduziu um novo método de prevenir cárie e iniciou a era corrente de ataque ácido na odontologia.

Desde então este material tem sido aprimorado através do acréscimo de pigmentos, carga, flúor e mudanças na forma de polimerização (GILPIN ${ }^{131}$, 1997; STRANG; WHITTERS ${ }^{327}$, 1998; LEINFELDER ${ }^{195}$, 1999).

A eficácia do tratamento está relacionada com a permanência do material nas áreas onde é aplicado e foi verificado que $64 \%$ dos dentes selados permaneceram assim após 7 anos ( CUETO; BUONOCORE ${ }^{79}$ ).

Qualquer procedimento técnico e/ou terapêutico que venha aumentar tal permanência concorre para o sucesso deste tratamento (HARRISON ${ }^{153}$, 1983; WENDT; KOCK $\left.{ }^{369}, 1988\right)$.

Definindo selantes BUSSADORI; IMPARATO; GUEDES PINTO ${ }^{56}$, em 2000, dizem: selantes de fossas e fissuras são materiais empregados como coadjuvantes no tratamento da doença cárie em dentes posteriores, que promovem o vedamento das fossas e fissuras obliterando o habitat preferível dos streptococcus mutans e facilitando a auto-limpeza, o que está de acordo com VERTUAN; BARELLI; SERRA ${ }^{358}, 1988$.

Atualmente encontram-se disponíveis no mercado selantes com material resinoso à base de polímeros, BIS-GMA e material sílico ou oxirresinoso .

$O$ presente trabalho estará fundamentado em pesquisas desenvolvidas por selante do tipo BIS-GMA fotopolimerizável. Dos selantes deste grupo têmse os auto e os fotopolimerizáveis. 
As vantagens dos selantes oclusais sugeridas na literatura são: aderem ao esmalte, obturando fisicamente fossas e fissuras por um período de um ano ou mais: não alteram a morfologia do dente; são inócuos aos tecidos bucais; requerem tempo de aplicação reduzido e polimerizam-se prontamente. Além destas, a satisfação de ter os dentes livres de cárie e a ausência de desconforto, quando comparado aos procedimentos operatórios normais do preparo de cavidades, são outras vantagens sugeridas pela ADA $^{6}$, em 1984.

A eficácia dos selantes oclusais tem sido demonstrada por vários autores, que foram categóricos ao afirmarem que os mesmos, enquanto intatos e retidos completamente, dão uma proteção de $100 \%$ às superfícies (ROCK; EVANS ${ }^{285}$, 1982; RYGE; BASKO ${ }^{291}$, 1983; ROCK ${ }^{282}$, 1984; SIMONSEN ${ }^{315}, 1991 \mathrm{~b}$; TRUHE $\left.{ }^{350}, 1991\right)$.

Este material, selante, em razão de sua promissora ação preventiva, tem sido pesquisado e testado sob os mais diversos meios e métodos. As respostas obtidas, nos vários tempos de observação, indicam excelentes níveis de redução da incidência da cárie dental oclusal, com direta relação à sua retentividade, KOPEL; GRENOBLE ${ }^{190}$, 1973; EDEN ${ }^{102}$, 1976; HOUPT; SHEY ${ }^{164}, 1979$; BROOKS et $\mathrm{al}^{45}$., 1979; FERGUSON; RIPA ${ }^{110}, 1980$; FUKS et $\mathrm{al}^{120}$., 1982; HOROWITZ164, 1982; STAM ${ }^{318}, 1983$; MERTZ-FAIRHUST et al ${ }^{228}$., 1984; TRUHEE ${ }^{350}$, 1991; FRANCO; MAGRO; CARVALHO ${ }^{119}$, 1994; MAIN; LEWIS; HAWKINS ${ }^{210}$, 1997; CROLL ${ }^{78}$, 1996; DAVIS ${ }^{85}$, 1998; e outros.

Um estudo clínico chave realizado por HOROWITZ; HEIFETZ; MCCUNE ${ }^{162}$, 1974, mostrou que molares perdem selantes com frequência duas vezes maior que a taxa estabelecida para pré-molares. Assim, o último e mais rigoroso teste de um selante para superfícies oclusais é sua permanência em molares.

Um fator que parece influir na permanência dos selantes é a presença de flúor no dente, seja ele sistêmico ou tópico (LOW et al ${ }^{206}$.,1982). Isto se deve ao fato de que os íons flúor determinam uma redução de energia de superfície dos cristais de hidroxiapatita dificultando, assim, a permanência do material (TAKAHASHI et $a^{339}, 1980$ ). Para que a permanência seja eficiente, é necessário que se aumente o tempo de ataque ácido, pois os cristais de fluorapatita são menos solúveis que os de hidroxiapatita (LOW et al ${ }^{205}$., 1975; LOW et $\mathrm{al}^{207}$., 1977); o que é indispensável, é a aplicação tópica de 
flúor após a aplicação do selante para a proteção de superfícies lisas (BOTAZZO; MANFREDINI; NARVAI ${ }^{33}$, 1989).

Autores têm sugerido que a aplicação de flúor tópico, após o selamento dos dentes, poderia agilizar a remineralização das áreas oclusais que tenham sofrido condicionamento ácido mas que não foram devidamente cobertas pelo selante, promovendo assim o aumento da permanência do material neste local (RIPA; LESKE; FORTE ${ }^{274}$, 1986; DUARTE; ISSAO ${ }^{100}$, 1987; VALSECKI; VERTUAN $^{353}$, 1988; JENSEN ${ }^{174}$, 1990; HICKS; FLAITZ157, 1992; KOH; CHAN; YOU $\left.{ }^{186}, 1998\right)$.

A busca na literatura a este respeito mostrou alguns aspectos interessantes, pois, pesquisadores como RIPA ${ }^{268}$, em 1973; RANTALA ${ }^{260}$, em 1979; RIPA ${ }^{269}$, 1980; TANAKA et $\mathrm{al}^{340}$. ., 1987; JENSEN ${ }^{176}$, 1990; CURY; $\mathrm{SAAD}^{83}$, 1993, SUNDFELD et $\mathrm{al}^{333}$., 1996, admitiram vantagens na combinação destes dois métodos de prevenção da cáries dentária.

Em 1976 RODER; SUNDRUN ${ }^{288}$, trabalhando em áreas com água fluoretada e não-fluoretada, descrevem um melhor comportamento dos selantes em áreas com água fluoretada, tanto no que diz respeito à permanência como no tocante à prevenção da cárie dentária.

As pesquisas desenvolvidas com os selantes de fossas e fissuras apresentam dados discrepantes na medida em que se consideram os diferentes tipos de material, as técnicas, os dentes, a idade dos dentes associados ou não com fluoretos (BOTAZZO; MANFREDINI; NARVAI ${ }^{33}$, 1989; DEERY et $a^{88}$. ., 1997).

Na prevenção o flúor tem ocupado um papel de destaque (WELLOCK; BRUDEVOLD ${ }^{368}$, 1963; BRUDEVOLD et al. ${ }^{48}$, 1963; SCHROTENBOER ${ }^{295}$, 1981). É sabido também que este halogênio oferece maior proteção nas superfícies lisas e que, nas superfícies oclusais, a sua eficácia é questionável, como bem demonstraram os trabalhos de DE PAOLA; AASENDEN; BRUDEVOLD ${ }^{92}$, 1971; GOURLEY ${ }^{138}$, 1975, HOROWITZ ${ }^{161}$, 1995. As cáries de fissuras dependem essencialmente de fatores do hospedeiro cujo controle se baseia principalmente na utilização de selantes, tendo sido averiguado que, quando os mesmos liberam flúor, a proteção é maior e também mais duradoura (DUARTE ${ }^{99}$, 1985; COOLEY et al. ${ }^{77}, 1990$ ).

$\mathrm{Na}$ tentativa de conferir um potencial preventivo, o flúor também tem sido adicionado em uma grande variedade de materiais, tais como cimentos, resinas compostas, selantes e amálgama (JENSEN $\left.{ }^{174}, 1998\right)$. 
No intento de combinar o efeito benéfico do flúor, com o selamento oclusal das fissuras, foi lançado no mercado odontológico um selante de fossas e fissuras fotopolimerizável, contendo, em sua composição, fluoreto de sódio e 50\% de partículas de carga inorgânica por peso (NAVARRO et al ${ }^{238}$., 1991; BERNARDES et $\mathrm{a}^{25}$., 1994; BOKSMAN; CARSON ${ }^{31}$, 1998).

Tal preocupação está ainda aliada à coerência de programas públicos envolvidos com uma filosofia preventiva mais ampla, face à observação dos altos índices de cáries existentes, principalmente na população infantil e de baixa renda de nosso país (BOTAZZO; MANFREDINI; NARVAl ${ }^{33}$, 1989; PINTO; LIMA ${ }^{251}$,1995; NARVAI ${ }^{236}$, 1996; PINTO ${ }^{252}$, 1997; SECRETARIA DE ESTADO DA SAÚDE DE SP, 1999 ${ }^{293}$ ).

Sendo assim, acredita-se que, apesar de não se conseguir mensurar a quantidade mínima de flúor liberada ideal para áreas de fossas e fissuras, a utilização de um selante resinoso com adição de flúor, como o Fluroshield, só trará benefícios para a qualidade final da técnica (TANAKA et al ${ }^{340} ., 1987$ ).

Além da liberação de flúor pelo selante Fluroshield ( JENSEN ${ }^{175}, 1990$; JENSEN; BILINGS; FEATHERSTONE ${ }^{176}, 1990$ ), pode-se considerar como fator de opção deste produto para o selamento de fossas e fissuras o seu custo, visto que nos últimos 6 meses o selante formulação com flúor tem se mantido com preço inferior aos dos cimentos inoméricos fotopolimerizáveis, que têm também sua indicação para esta técnica de selamento.

Foi realizado o estudo da possibilidade da combinação dos efeitos do flúor e dos selantes de sulcos, fossas, cicatrículas e fissuras, aplicando o flúor gel assim que finda a técnica de selamento. 


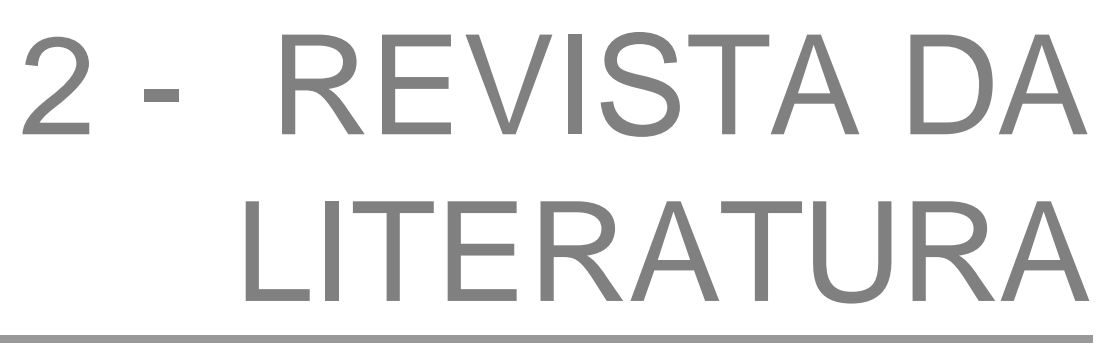




\section{2 - ReVISTA DA LITERATURA}

Diante da alta incidência de lesões de cárie na superfície oclusal dos dentes, muitos métodos preventivos vem sendo desenvolvidos na tentativa de retardar ou bloquear esse processo.

Em 1885, BLACK já preconizava a extensão preventiva,

Em torno de 1895, WILSON propôs a restauração de cicatrículas e fissuras com cimento.

BLACK, em 1924, preconizava para as lesões cariosas de cicatrículas e fissuras, mesmo aquelas incipientes, um tratamento com base no princípio da "extensão para prevenção", cuja idéia básica era prevenir recidivas, englobando todas as cicatrículas e fissuras.

HYATT ${ }^{167}$, em 1923, para quem "o defeito no esmalte hoje é a cárie de amanhã", recomendava um tratamento preventivo de sulcos e fissuras através da odontotomia profilática, na qual as fissuras eram mecanicamente preparadas e preenchidas com amálgama. Este tratamento permanece sujeito a controvérsias, pois remove parte sã da estrutura dental e não é verdadeiramente preventivo.

PRIME $^{257}$, em 1926 e depois BODECKER ${ }^{27}$, em 1929, propuseram a "erradicação das fissuras", com a utilização de uma broca esférica, tornandoas em sulcos rasos e não retentivos.

HYATT $^{168}$, em 1931, afirmou que muitas falhas nas superfícies oclusais dentais eram difíceis de serem vistas (diagnosticadas) e tratadas preventivamente.

BOSSERT ${ }^{32}$, em 1933, relacionou a conformação da anatomia oclusal com o aparecimento de cáries nessas superfícies dentais.

$45 \%$ de todas as cáries em dentes permanentes de crianças de 13 anos de idade envolvem superfícies oclusais de acordo com DAY; SEDWICK ${ }^{86}$, 1935, MARSHALL; SEDWICK ${ }^{213}, 1935$.

$\mathrm{Na}$ década de 1950 tentaram-se vários tratamentos com métodos químicos; nitrato de prata, cloreto de zinco, ferrocianeto de potássio e 
cimento de cobre vermelho, todos com pouco sucesso clínico. Nenhum destes tratamentos provou ser eficiente.

Porém, somente em 1955, com a introdução do condicionamento ácido por BUONOCORE ${ }^{51}$, foi possível a união do esmalte com a resina acrílica, possibilitando um grande avanço aos materiais adesivos.

Um dos trabalhos pioneiros sobre selante de fóssulas e fissuras, foi o de BUONOCORE ${ }^{51}$; em 1955 desenvolveu a técnica do ataque ácido para restaurações com resina acrílica e, sugere a utilização de um material acrílico, após o tratamento da sua superfície de esmalte com ácido, como um método de prevenção de cáries e em 1968 utilizou o cianocrilato e pó de silicato como selante de cicatrículas e fissuras.

Em 1959 STEWART ${ }^{203}$ afirmou que, apesar das críticas existentes à odontotomia profilática de HYATT $^{167}$, nos indivíduos com muitas lesões cariosas deveria ser realizado um desgaste preventivo nas fissuras, que afirmou serem "pré-cariadas", e publica um trabalho onde sugere modificações em instrumentos rotatórios para facilitar o desgaste dentário preventivo, deixando as superfícies oclusais com menos áreas retentivas.

Em 1963 BOWEN $^{34}$ sintetizou a resina composta BIS-GMA, publicando trabalhos, sobre a adesividade da resina aos tecidos dentários (1965 ${ }^{34}$, $\left.1965^{35}, 1965^{35}\right)$. Subsequentemente estes trabalhos criaram as bases para a utilização dos selantes (ataque ácido e resina) como medida preventiva.

Em um outro estudo sobre dentes não protegidos BACKER DIRKS ${ }^{17}$, 1961, encontrou cárie, quase que em caráter universal, nos primeiros molares permanentes aos nove anos de idade e nos segundos molares permanentes aos quatorze anos de idade.

Em 1963 BUONOCORE ${ }^{52}$, afirma que o adesivo ideal seria aquele que possibilitasse uma união duradoura, quer com o esmalte quer com a dentina, polimerizasse a uma temperatura próxima aquela do corpo humano, com pouca ou nenhuma contração, com resistência suficiente para suportar as cargas mastigatórias, tivesse coeficiente de expansão térmica linear idêntica à do dente, fosse inofensivo à polpa dental e aos tecidos bucais, fosse resistente à degradação no meio bucal, afirmação esta reforçada em trabalho do mesmo autor publicado em 1973. 
Em 1967 GWINNETT; BUONOCORE ${ }^{146}$, publicaram trabalho sobre a valiosa possibilidade da utilização de materiais adesivos na prevenção de cáries. O primeiro selante de fossas e fissuras passou por um teste clínico em 1967, mostrando $71 \%$ na redução das lesões cariosas na superfície oclusal. Em 1967 CUETO; BUONOCORE ${ }^{79}$ utilizando uma amostra de 269 indivíduos, na faixa etária de 5 a 17 anos, descreveram uma redução média de cáries oclusais, após 12 meses, de 89,3\%; 85,7\% e 93,2\%, respectivamente para os primeiros e segundos pré-molares, primeiros molares e segundos molares.

A descoberta que a incidência de cáries em cicatrículas e fissuras de molares e pré-molares permanentes pode ser reduzida em $89,3 \%$ obturandoos com um adesivo em intervalos de 6 em 6 meses indicou a utilidade potencial desse processo na odontologia preventiva. É significante que altas reduções de cáries podem ser feitas nos molares, pois essas superfícies oclusais são mais suscetíveis ao ataque de cárie que as outras superfícies do dente, e elas também são beneficiadas pela ação do fluoreto.

É também importante, disseram CUETO; BUONOCORE ${ }^{79}$, em 1967, selar cavidades e fissuras o mais cedo possível depois do nascimento dos primeiros molares, pois o pico de ataque das cáries interproximais ocorre alguns anos depois dessa irupção. Esse intervalo de tempo é provavelmente aumentando pela adição de flúor à água potável ou tratamentos modernos com fluoreto.

Foi pensado que o selamento teria valor para crianças novas quando pudesse haver problemas de manejo e quando os processos de corte são difíceis. Em tais pacientes o selamento com adesivos proporcionaria uma introdução fácil e aceitável à odontologia que poderia manter as cavidades e fissuras livres de cáries por anos. Em algumas pessoas, o selamento de cavidades e fissuras poderia ser o único tratamento requisitado até que os pré-molares e segundos molares irrompessem. Depois de 6 meses e 1 ano, houve a cobertura completa em $80,2 \%$ e $71,2 \%$ dos dentes, respectivamente. Aqueles dentes cobertos em visitas de retornos de 6 meses poderiam ser programados para 6 meses depois. Aqueles dentes, os quais foram selados e subsequentes tornaram-se parcial ou totalmente descobertos foram não mais suscetíveis à cárie que os dentes controlados que são mostrados no estudo de CUETO; BUONOCORE ${ }^{79}$, onde sua incidência de cárie foi $7 \%$ menos que os dentes controlados. No grupo de 
dentes individuais, os primeiros e segundos molares parcialmente descobertos, tinham cerca de $80 \%$ e $89 \%$ menos cáries, respectivamente, que dentes controlados.

Nos dentes com perda total de cobertura do selante, cerca de $50 \%$ menos cáries foram achados nos primeiros pré-molares e molares tratados que dentes similares controlados.

Outra possibilidade para a incidência mais baixa de cáries em dentes parcial e completamente descobertos, disseram os autores, poderia ser relatada ao fato que pistas do material não prontamente detectados foram registrados para regiões de dentes parcial e totalmente cobertos.

A incidência de cárie (18,6\%) em dentes completamente descobertos foi mais que duas vezes maior que nos grupos parcialmente descobertos $(7,8 \%)$. Essa diferença em taxas entre os resultados das duas categorias é devido ao fato que um dente que se torna completamente descoberto, geralmente tem duas regiões (mesial e distal) para a superfície oclusal dos pré-molares inferiores e 3 regiões (mesial, central e distal) para cada um dos outros dentes que são expostas ao ataque de cárie, ao passo que, para dentes parcialmente descobertos, geralmente só um e em casos raros, duas regiões são expostas. Desde que no estudo de CUETO; BUONOCORE ${ }^{79}$, um dente foi considerado cariado quando qualquer região de fissura se tornasse cariado, as chances para classificar um dente como cariado na amostra completamente descoberta, foi maior pelo fator de dois a três que em dentes do grupo parcialmente descobertos, os quais estão em concordância com a diferença observada. A maior incidência de superfícies completa e parcialmente descobertas durante o período dos segundos 6 meses pode ser relacionada à técnica usada no exame. A maioria das superfícies foram tratadas novamente depois de 6 meses aplicando um novo adesivo diretamente sobre o material do tratamento anterior.

Essa demonstração inicial, no estudo de CUETO; BUONOCORE ${ }^{79}$ de 1967, de que a resina pode ser fortemente aderida ao esmalte humano por períodos longos, proporcionou encorajamento para os vários efeitos de pesquisas, direcionados no desenvolvimento de adesivos clinicamente práticos para a Odontologia Preventiva e Restauradora.

Em virtude de elevado número de trabalhos publicados relacionados aos vários fatores que envolvem o sucesso clínico da técnica de selamento 
oclusal, optou-se por subdividir a revista da literatura em tópicos, com o intuito de que se torne mais didática.

Cada um dos tópicos a seguir discorrerá sobre um ou mais fatores relacionados à técnica de selamento oclusal. 


\subsection{AVALIAÇÃO DO TEMPO DE PERMANÊNCIA E EFETIVIDADE DO SELAMENTO OCLUSAL.}

Iniciando com os trabalhos de BUONOCORE ${ }^{51}$, em 1955, e de BUONOCORE $^{48}$, em 1963, a partir do trabalho de CUETO; BUONOCORE ${ }^{79}$, em 1967, o uso dos selantes vem crescendo a cada dia, ocorrendo uma maior conscientização da importância de selar as superfícies oclusais, as quais apresentam uma morfologia extremamente complexa, variando de indivíduo para indivíduo, de dente para dente e em uma mesma superfície de um único dente, em que sua grande profundidade e sua pequena largura tornam-nas um meio de permanência para bactérias e alimentos.

PHILLIPS $^{250}$ (1966), salientou que a permanência do selante na superfície dentária é condição precípua para que sua característica anticariogênica se estabeleça.

Segundo GWINNETT; MATSUI ${ }^{147}$, em 1967, a permanência do selante ao dente está diretamente relacionada com sua capacidade de penetração e escoamento. O material selador precisa apresentar, nesta situação, características como baixa viscosidade, alta tensão superficial e baixo ângulo de contato.

HENNON; STOOKEY; MUHLER ${ }^{155}$, em 1969, relataram que as faces oclusais dos dentes segundos e primeiros molares permanentes são as mais suscetíveis à lesões cariosas.

Em 1970 BUONOCORE ${ }^{53}$, trabalhando com selante de resina em 60 crianças, reduziu em 99\% o índice de cárie após um período de 15 anos. Esse trabalho fundamentou a ação dos selantes como medida preventiva e inúmeras outras publicações têm demonstrado a efetividade na prevenção de cáries com o uso de selante de fossas, cicatrículas e fissuras. 
Neste mesmo ano RIPA; COLE ${ }^{273}$, demonstraram permanência eficaz e redução de cáries. Entretanto, características de difícil manejo e necessidade de reaplicações a cada seis meses limitaram o valor do cianocrilatos.

Os primeiros materiais resinosos empregados para o selamento oclusal eram polímeros pertencentes ao grupo dos cianocrilatos, os quais, mesmo sendo portadores de satisfatória penetração no esmalte dental condicionado, apresentavam considerável solubilidade no meio oral e destacavam-se facilmente, necessitando, desse modo, serem reaplicados periodicamente.

Na procura constante, por parte dos pesquisadores, de compostos mais estáveis, surgiram as resinas tipo Bis-GMA, com comportamento clínico superior às anteriormente citadas.

Em 1971 BUONOCORE ${ }^{54}$, relatou que 50\%, dos selantes aplicados estavam perdidos nos decíduos e $87 \%$, nos molares permanentes, e verificou uma efetividade de $99 \%$ e $87 \%$ na redução de cáries oclusais em molares permanentes e decíduos, respectivamente. Neste trabalho ele disse achar 0 detalhe mais importante do estudo o fato de encontrar proteção quase completa contra o desenvolvimento de cáries em fossas e fissuras de dentes permanentes dois anos após uma única aplicação de uma resina adesiva para selar essas áreas vulneráveis. Finalizou reafirmando que o selamento por meio de adesivo deve ser parte importante nos programas de prevenção de cáries para uso na prática clínica, pois esse é especialmente indicado para aplicação nas áreas suscetíveis à cáries que são menos beneficiadas pelo fluoreto.

MONUS; GRENOBLE ${ }^{234}$, em 1971, estudando "in vivo" a remineralização do esmalte após ataque com solução de ácido fosfórico a 50\%, constataram que após uma hora, em presença da saliva, a superfície do esmalte já apresentava sinais de recuperação, provavelmente devido a deposição de fosfatos de cálcio existentes na saliva. Após 96 horas, a superfície do esmalte atacado retornou à condição de normalidade. Disseram que, se o esmalte sofrer um ataque ácido e não for recoberto por um selante, remineralizará em presença da saliva. 
JACKSON; MURRAY; FARPO ${ }^{173}$, em 1973, demonstraram que quando comparando a experiência de cárie em grupo de adolescentes com 15 anos de uma comunidade com água não fluoretada com um grupo de adolescentes de idade similar e moradores em uma comunidade em que a água de beber continha entre 1.5 a 2 partes por milhão (ppm) de flúor; encontraram uma grande inibição de cárie em superfícies dentais lisas naqueles que ingeriam água fluoretada.

ROCK $^{279}$, em 1973, relata redução estatisticamente significante na incidência da cárie usando materiais a base de Bis-GMA.

HANDELMAN; BUONOCORE; SCHOUTE ${ }^{150}$, em 1973, selaram dentes posteriores com cáries incipientes e observaram uma diminuição de 50 vezes o número de microorganismos cultivados na dentina dos dentes selados. Entretanto, os pesquisadores disseram que, naquele momento mais estudos eram necessários antes que esse procedimento se tornasse um método de rotina.

RETIEF ${ }^{265}$, em 1973, verificou que utilizando-se ácido fosfórico a 50\% no esmalte, ocorreria um íntimo contato interfacial entre o adesivo e 0 tecido dental, e um aumento na facilidade de umectação superficial. Observou microscopicamente que a medida em torno de 50 micrômetros de comprimento foi a alcançada aos prolongamentos resinosos que penetraram no esmalte condicionado.

GWINNET; RIPA ${ }^{148}$, em 1973, observaram que, mesmo em casos de perda parcial do selante, o esmalte na região das fossas e fissuras continua protegido do ataque de cárie, e nisso foram corroborados por GOING et al. (1976).

ROCK ${ }^{280}$, em 1974, após 2 anos de experimento, relatou dados da eficácia dos selantes Nuva Seal e Epoxylite-9075. Descreveu uma permanência total média de $80 \%$ com o Nuva Seal e 51,5\% com o Epoxylite9075 em pré-molares e molares permanentes. 
Em 1974 HOROWITZ; HEIFETZ; MCCUNE ${ }^{162}$, utilizando selante ativado com luz ultravioleta após 24 meses descrevem uma permanência total de $73 \%, 14 \%$ de perda parcial e $16 \%$ de perda total. Por grupo de dentes, os autores encontraram uma permanência média de $83,12 \%$ nos pré-molares e $42,65 \%$ nos molares permanentes.

Relativamente as cáries oclusais os autores relatam que, no grupo controle, $24,9 \%$ dos dentes estavam cariados, contra $8,2 \%$ dos dentes selados. Neste estudo clínico chave realizado por HOROWITZ; HEIFETZ; MCCUNE ${ }^{162}$, 1974, mostraram que molares perdem selantes duas vezes mais que a taxa estabelecida para pré-molares. Assim, disseram, o último e mais rigoroso teste de um selante para superfícies oclusais é o de sua permanência em molares.

Em trabalhos publicados sobre o selamento de fossas, cicatrículas e fissuras como procedimento da odonto-preventiva, BUONOCORE ${ }^{54}$, 1971; SILVERSTONE ${ }^{307}$, 1974; ROCK; ANDERSON ${ }^{283}$, 1982; ROCK et al287., 1989, afirmaram que os materiais utilizados para o selamento das fissuras deveriam ter as seguintes propriedades: união físico-química a estrutura dentária, resistência aos ácidos bucais, integridade superficial, compatibilidade química com tecidos bucais, ação cariostática.

Desvantagens dos selantes, de acordo com MCLEAN; WILSON ${ }^{220}$, em 1974: não formam ligações hidrolíticas estáveis, baixa resistência ao desgaste, baixo módulo de elasticidade, alta ocorrência de expansão e contração térmica. Portanto, para esses autores, a união do selante com o dente depende da durabilidade da união mecânica criada pelo condicionamento ácido e pela integridade da resina.

De acordo com BARBOSA; GARONE FILHO ${ }^{21}$ (1974), FERRARA ${ }^{111}$ (1975), ULVESTAD ${ }^{353}$ (1976), dos selantes mais estudados estão os dos tipos cianocrilatos, poliuretanos e o BIS-GMA (produto de reação do bisfenol A e do metacrilato de glicídeo). Destes três, os dos tipos dos cianocrilatos e poliuretanos estão praticamente abandonados, visto que os cianocrilatos, apesar de apresentarem uma boa adesão ao esmalte, sofrem decomposição quando expostos ao meio (bucal RIPA ${ }^{270}, 1982$ ). Os selantes do tipo poliuretanos também praticamente estão descartados, visto que, de acordo com $\operatorname{ROCK}^{278}$ (1972), não apresentam capacidade para produzir uma união duradoura com o esmalte. 
Segundo BARBOSA; GARONE FILHO ${ }^{21}$, em 1974, as finalidade e efeitos do ataque ácido previamente à aplicação do selante são: criar ou aumentar os poros existentes, para possibilitar uma micro-imbricação mecânica, além de resultar num aumento da área disponível para a união.

Apesar da finalidade principal do ataque ácido ser puramente mecânica, a remoção da camada mais externa do esmalte expõe uma camada mais interna, que por sua vez apresenta uma maior energia de superfície, influindo positivamente num aumento da capacidade de "molhamento" do selante em relação ao esmalte.

O selante se ligaria ao esmalte condicionado por solução ácida com uma força 500 vezes maior do que ao esmalte não tratado, de acordo com ROCK ${ }^{280}, 1974$; os "microporos" criados pela solução penetram entre os "prismas" do esmalte. Poderá haver de 30 a 40 mil prismas por milímetro quadrado, de modo que a superfície disponível para junção é enormemente aumentada. Os selantes penetram nos "microporos", formando milhões de micro-estiletes no interior do esmalte estabelecendo uma íntima ligação mecânica.

GARONE NETTO; GARONE FILHO'24, em 1975, analisando através de microscópio eletrônico de varredura, a interface resina/esmalte condicionado, verificaram que as soluções ácidas provocam desmineralização no esmalte dentário, resultando criação de espaços, onde as resinas de baixa viscosidade penetram e se polimerizam.

No ano de 1975 GOURLEY'138, descreveu uma permanência do selante de $93 \%$ e $78 \%$ nos dentes decíduos e permanentes, após 2 anos de acompanhamento. Nesse trabalho, o autor admite que a melhor permanência dos selantes era devida ao tempo de ataque ácido, que foram de 90 segundos para decíduos e de 60 segundos para os permanentes.

MARSHALL; OSLON; LEE ${ }^{214}$, em 1975, utilizaram ácido fosfórico a $50 \%$ nas superfícies de pré-molares e molares. Isso aumentou a área superficial do esmalte e produziu desmineralização dos prismas. As fissuras mais profundas não foram atingidas pelo ácido, ficando este mais restrito as inclinações cuspídeas. Os molares foram mais resistentes ao condicionamento que os 
pré-molares. Com um maior tempo de condicionamento, 60 segundos, obteve-se uma melhor adaptação do selante à paredes de esmalte.

Neste mesmo ano, HELLE ${ }^{154}$, utilizando dois tipos de selantes BIS-GMA (Nuva Seal e Concise) em molares permanentes, pré-molares, e molares decíduos, descreve uma permanência de $100 \%, 96 \%$ e $91 \%$ em molares permanentes, após 6,12 e 18 meses de controle, e de 100\% de permanência nos pré-molares, após 18 meses. Nos molares decíduos, descreve uma permanência de 95,6\%, 81,2\% e 72,3\%, após 6,12 e 18 meses.

No que diz respeito a cáries oclusais, encontra no grupo teste $2,3 \%$ de dentes cariados e $49,3 \%$ no controle, isto, para os dentes permanentes, e $1,7 \%$ e $33,6 \%$ nos dentes decíduos, respectivamente para os grupos teste e controle.

APOSTOLIDIS; O'BRIAN; FAN"1, em 1975, ressaltaram a importância de uma técnica de aplicação de selante que não forme bolhas de ar, envolvendo-as dentro das fissuras. Isto pode acontecer quando o selante é pincelado de distal para mesial com uma escova, afirmam os autores. $O$ método de aplicação deve permitir que o selante flua e se espalhe delicadamente sobre a superfície. Devido à alta capacidade de escoamento, o produto passa rapidamente através da ponta do aplicador para o dente. $O$ selante cobre a superfície, flui e penetra nas fissuras sem o inconveniente dos esfregões do pincel.

A permanência e proteção dadas por um selante dependem de uma completa penetração nos "microporos" do esmalte condicionado com ácido $\mathrm{e}$ nas intrincadas fissuras das superfícies dos dentes. A baixa viscosidade e escoamento são fatores que contribuem para a alta penetração o que FAN; SELUK; O'BRIAN ${ }^{106}$ (1975) expressaram como Coeficiente de Penetração. APOSTOLIDIS; O'BRIAN; FAN"11 (1975), relatam que é necessário um Coeficiente de Penetração de pelo menos $0,24 \mathrm{~cm} / \mathrm{seg}$. para preencher fissuras estreitas. Os "microporos" podem ser muito mais estreitos do que as próprias fissuras. Quanto mais alto for o Coeficiente de Penetração, melhor cobertura, penetração e permanência se pode esperar do selante. 
HANDELMAN; WASHBURN; WOPPERER ${ }^{151}$, em 1976, realizaram um estudo nos quais dentes que tinham cáries de fossas e fissuras foram selados com um selante polimerizado por luz ultravioleta; amostras de dentina cariada foram feitas dos dentes que não foram selados e dos dentes que foram selados, depois de 2 anos que o selante tinha sido aplicado. Foi verificado uma maior redução em microrganismos viáveis ocorrido durante as primeiras duas semanas e uma redução gradual na contagem total ocorreu depois disso. Ao final dos 2 anos, existiu uma diminuição 2000 vezes no número de microrganismos cultiváveis. Achados clínicos e radiográficos preliminares das lesões cariosas sugeriram que não havia progressão das lesões cariosas.

Os resultados de 2 anos de estudo prolongado é a confirmação dos resultados anteriormente encontrados, nos quais foi suposto que o tratamento de cáries incipientes ou moderadamente avançadas com um selante oclusal pode retardar ou prevenir o progresso de cárie. Embora em algumas lesões um número limitado de microrganismos cultiváveis persistam, os seus números foram extremamente baixos e não parecem ser capazes de continuar a destruição da estrutura dental. Seria coerente assumir, disseram os autores, que isto foi o resultado de um suprimento inadequado de nutrientes úteis as bactérias aprisionadas.

GOING et al $^{134}$., em 1976, publicaram um estudo sobre a permanência clínica e a perda do selante após 2 anos. Foi usado o selante Nuva Seal, e foram examinadas 84 crianças de 10 a 14 anos, provenientes de uma área não fluoretada. Em 479 pares de dentes permanentes e 20 pares de dentes decíduos utilizou-se um selante de coloração vermelha. Em uma hemi-arcada foi aplicado selante, tendo a outra sido usada como controle. Esses pesquisadores criaram uma classificação (de A a D), como segue, para facilitar na fase de reexame:
A - não apresenta perda de selante
$B$ - pequena perda de selante
C - grande perda de selante
D - perda total do selante 
Após 3 meses, houve uma permanência completa em $92 \%$ de todos os pares de dentes permanentes. Depois de 6 meses, a permanência foi de $86 \%$, após 12 meses, de $81 \%$ e com 24 meses, de 69\%. Com exceção do segundo MS, o selante ficou bem retido nos molares, nos pré-molares e na superfície lingual do incisivo superior. A permanência dos selantes foi mais evidentes nos pré-molares do que nos molares, com índices de $94 \%$ e $47 \%$, respectivamente. A permanência do segundo pré-molar foi maior do que a do primeiro pré-molar, e a permanência do primeiro pré-molar foi superior à do segundo molar. A permanência do selante na mandíbula foi maior do que na maxila. Nesse estudo, o dente foi dividido em três regiões e constatou-se que a maior perda do selante ocorreu na região mesial do dente. O primeiro molar superior quase não teve nenhuma permanência na área mesial, ao passo que o segundo pré-molar inferior foi o dente com maior índice de permanência.

BROOKS; MERTZ-FAIRHURST ${ }^{44}$, em 1976, num estudo comparativo entre dois tipos de selantes BIS-GMA, um polimerizado com luz ultravioleta (Nuva Seal) e outro autopolimerizável (Delton), descreveram, após 12 meses de aplicação dos materiais em crianças de 6 a 8 anos, uma melhor permanência do selante autopolimerizável. Em primeiros molares permanentes inferiores, encontraram uma permanência total de 95,9\%, uma parcial de $0,8 \%$ e uma perda total de 3,3\% para o Delton, e uma permanência total de $88,3 \%$, uma parcial de $7,5 \%$ e uma perda total de $7,7 \%$ para o selante Nuva Seal. Em dentes superiores, a permanência total dos dois selantes testados são menores, ou seja: $93,2 \%$ e $78,6 \%$ para o selante Delton e Nuva Seal respectivamente, dando uma média nos superiores e nos inferiores, percentuais de $84,6 \%$ e $83,5 \%$ de permanência total do selante autopolimerizável e o ativado com luz ultravioleta.

Ainda em 1976 ULVESTAD $^{352}$, utilizando o selante do tipo BIS-GMA, autopolimerizável, Concise, desenvolveu uma pesquisa em 69 escolares de 6 a 12 anos. No grupo de escolares, da faixa etária de 6 a 9 anos, efetuou o selamento nos primeiros molares permanentes e no grupo de 9 a 12 anos, nos pré-molares e segundos molares. Após 24 meses de acompanhamento, observou que, nos pré-molares e nos primeiros molares inferiores, a 
permanência total na face oclusal foi de $100 \%$. No entanto, o autor relata uma permanência de $91,0 \%$ nas fissuras vestibulares dos primeiros molares inferiores, de $97,0 \%$ na fossa central, outra de $95 \%$, na fissura e outra de $93 \%$, no sulco disto lingual dos primeiros molares superiores.

ALVESALO; BRUMMER; LEBEL ${ }^{3}$, em 1977, aplicando o selante Nuva Seal em primeiros molares permanentes e molares decíduos em crianças na faixa etária de 6 a 7 anos, descreveram, após 12 e 24 meses, uma permanência boa de $74,0 \%$ e $40,0 \%$ nos molares permanentes e de $67,0 \%$ e $45,0 \%$ para os decíduos. Quanto à cárie, encontraram nos permanentes, uma redução de $84,0 \%$ e 53,0\% e nos decíduos, uma de 84,0\% e 42,0\%, após 12 e 24 meses.

BREAKSPERE; CHEM; WILTON ${ }^{43}$, em 1977, reportaram os resultados da avaliação "in vitro" da interface selante/esmalte, variando os métodos de aplicação do ácido, viscosidade e secagem do esmalte. Os métodos de aplicação do ácido na superfície de molares foram a utilização de pincel, bolinha de algodão ou gotejado sobre o esmalte, aí mantido por 30 segundos. Para a seleção das soluções de monômeros de diferentes viscosidades, misturam-se grãos polimerizados pequenos no Nuva Seal em variadas proporções que foram comparadas ao selante puro, sem polimerização. $O$ efeito da contaminação da superfície de esmalte foi medido através da secagem com ar e secagem com papel absorvente. Após a realização dos testes, o filme de selante foi removido do dente por dissolução do esmalte com ácido clorídrico e a presença de prolongamentos do selante em contato com o esmalte foi investigada usando microscópio eletrônico de varredura. Os resultados mostraram que para uma efetiva união do selante ao esmalte foi requerido que este fosse aplicado com pincel no esmalte condicionado e seco com ar comprimido, livre de contaminação. A viscosidade do selante pareceu não ter importância na união selante/esmalte.

CHARBENEAU; DENNISON; RYGE72, em 1977, utilizando o selante "Kerr Pit and Fissure Sealant" em molares decíduos e permanentes de crianças na faixa etária de 5 a 8 anos, relataram uma melhor permanência nos 
permanentes, quando comparados com os decíduos. Assim, descrevem uma permanência do selante de $90,6 \%, 79,2 \%$ e $74,0 \%$, nos dentes permanentes, e de $88,3 \%, 72,5 \%$ e 62,2\%, nos decíduos, após a avaliação de 6,12 e 18 meses. Quanto à eficácia na redução de cáries, 18 meses após, encontraram uma redução de $75,9 \%$ em molares permanentes e $85,7 \%$ nos decíduos.

O efeito benéfico dos selantes sobre cáries é conhecido. GOING; LOESCHE ${ }^{132}$, em 1978, selaram com Nuva Seal cáries detectadas clinicamente e após 5 anos verificaram áreas negras sob esses selantes, clinicamente intactos, os quais demonstraram cultura bacteriana negativa ou em baixa concentração.

THYLSTRUP; POULSEN ${ }^{345}$, em 1978, após uma única aplicação do selante Concise em primeiros molares permanentes de 217 crianças com idade aproximada de 7 anos, relataram, nos superiores, uma permanência de $43,5 \%$, na fossa distal e $75,5 \%$, na fossa mesial, e nos inferiores uma de $59,5 \%$, com uma média de $59,5 \%$, com uma média de $59,5 \%$, após 2 anos de controle. Quanto às perdas parciais, encontraram uma freqüência de $7,5 \%$ na fossa distal e 5,4\% na fossa mesial, nos superiores e 19,6\% nos inferiores, com uma média de $11,1 \%$. Relacionaram a perda do selante com a freqüência de cáries oclusais $e$, assim quando compararam o grupo experimental com a perda total do selante com o grupo controle, encontraram uma redução de 9,8\%. Quando relacionaram o grupo de perda parcial do selante com o grupo controle, encontraram uma redução de 50,0\% e, finalmente, nos dentes sem perda de selante com os dentes não selados, uma redução de 97,5\% de cárie dentária, após 24 meses de pesquisa.

Em média, THYLSTRUP; POULSEN ${ }^{345}$, em 1978, após uma única aplicação do selante Concise em primeiros molares permanentes obtiveram, uma permanência total do selante de $98,8 \%, 98,4 \%, 96,1 \%$, respectivamente após 3, 6 e 12 meses de acompanhamento.

POULSEN et $a^{253}$., em 1979, objetivando estudar o comportamento dos selantes nas condições de programas de saúde dental pública em crianças, 
verificaram que o selante "Concise" apresenta um percentual de $81,8 \%$ de permanência parcial, após 24 meses de experimentação.

Neste mesmo ano RANTALA ${ }^{260}$, utilizando escolares na faixa etária de 7 a 9 anos, estudou a eficácia da utilização combinada de selantes com aplicações tópicas de fluoreto acidulado. Após 2 anos de acompanhamento, informou que este uso combinado determinou um aumento de primeiros molares permanentes livres de cáries de $50,0 \%$ para $81,0 \%$.

Ainda em 1979 CLINE; MESSLER ${ }^{76}$, descreveram uma permanência completa do selante "Nuva Seal" de 14,0\% em molares decíduos, 25,0\% em molares permanentes e 68,0\% em pré-molares, após um período de 4 anos. No desenvolvimento da pesquisa utilizaram inicialmente, crianças de 4 a 7 anos, para o selamento de dentes decíduos, e até 14 anos, em permanentes recém-irrompidos.

HOUPT; SHEY ${ }^{164}$, em 1979, utilizando uma amostra de 205 crianças na faixa etária de 6 a 10 anos, descreveram uma permanência nos primeiros molares permanentes de 97,0\%, 92,0\%, 85,0\% e 77,0\% do selante Delton, com avaliação após 5, 11, 24 e 33 meses, respectivamente. Quanto às cáries oclusais, relataram uma prevenção de $94,0 \%$ após 5 meses, de 90,0\% após 11 meses, de 88,0\% após 24 meses e 78,0\% após 33 meses.

Em 1980, SIMONSEN ${ }^{306}$, aplicando o selante "Delton", em 1.100 dentes decíduos e permanentes de crianças na faixa etária de 3 a 15 anos, residentes em zonas com um teor de 1,2 p.p.m. de flúor, relatou uma melhor permanência do selante em dentes decíduos que nos permanentes, ou seja, uma permanência total de $96,0 \%$, parcial de $4,0 \%$ nos dentes permanentes e uma permanência total de $98,8 \%$ e uma parcial de $1,2 \%$ para os dentes decíduos, após 24 meses de uma única aplicação do material.

RIPA $^{269}$, em 1980, comparou o selante de fossas e fissuras com outros métodos preventivos e observou, após 5 anos, os seguintes resultados com relação aos seus potenciais preventivos: 


\begin{tabular}{l|l}
\hline CPO-S & $\%$ de redução \\
\hline -água potável fluoretada & $50-65$ \\
\hline - pastilhas de flúor & $25-40$ \\
\hline - bochechos com flúor & $20-25$ \\
\hline - profilaxia e aplicação tópica de flúor & $30-40$ \\
\hline - selamento de fossas e fissuras & $58-60$ \\
\hline
\end{tabular}

Nesses números de RIPA ${ }^{269}$, a aplicação do selante aparece como o melhor procedimento na prevenção geral das cáries.

AXELSSON; LINDHE ${ }^{16}$, em 1981, publicaram um estudo onde demonstraram claramente que um programa preventivo que estimula cuidados individuais pode prevenir cáries e patologias periodontais. $O$ aumento do tempo devotado aos cuidados preventivos é compensado pelo decréscimo de tempo necessários para procedimentos restauradores.

A diminuição da prevalência de cárie que, durante as últimas décadas, se verificou principalmente em relação com a utilização dos fluoretos, devese a uma diminuição do número de cáries com localização nas superfícies lisas. A ação cariostática do flúor é muito menos acentuada nas superfícies rugosas de fossas e fissuras. Com efeito, em 1981, foram publicados os resultados de uma investigação realizada nos Estados Unidos, os quais demonstraram que $84 \%$ das cáries em crianças dos 5 aos 17 anos envolvem superfícies de fossas e fissuras.

Um estudo efetuado por ROCK; BRADNOCK ${ }^{284}$, em 1981, com selamento de molares e pré-molares revelou $81 \%$ de efetividade após um ano e 65\% de efetividade após 3 anos. Os autores selaram 220 dentes primeiro molares permanentes com selante resinoso autopolimerizável Delton. Constataram também, após 3 anos, que os primeiros molares superiores tiveram maior porcentagem de perda total de selante $(47,7 \%)$ se comparados com a perda nos inferiores $(39,0 \%)$.

SIMONSEN ${ }^{307}$, em 1981, verificou baixo índice de dentes com recidiva de cárie ( 18 ou $5,2 \%$ ), sendo que em $3,18 \%$ a presença de selante era parcial e em $2,02 \%$ observou-se ausência total. Saliente-se ainda que nos 17 casos 
$(4,92 \%)$ onde o selante não estava presente, não foi constatada cárie. Estes aspectos indicam a necessidade de controles periódicos por parte do profissional, no sentido de avaliar a integridade do selante em períodos constantes (seis em seis meses) com relação a sua permanência parcial ou total e desgaste. Também ressaltou que a aplicação de selantes oclusais não é medida de prevenção exclusiva, havendo necessidade de sua associação a outros métodos.

Selamento de fossas, cicatrículas e fissuras, disseram ROCK; ANDERSON $^{283}$, em 1982, tem se mostrado um importante componente em qualquer programa dental. Entretanto não tem sido usado extensivamente como se pensava de início. Estudos revisando um bom número de avaliações clínicas tem confirmado uma positiva correlação entre a terapia de selante e sua eficácia, sugerindo que cada 100 primeiros molares permanentes selados 32 tem a prevenção quanto a ficarem cariados.

Em 1982 MERTZ-FAIRHURST et al ${ }^{227}$., continuando o trabalho publicado em 1981(MERTZ-FAIRHURST ${ }^{226}$ ), relataram os dados do estudo comparativo de permanência entre o "Delton" e "Nuva Seal", após 6 anos de acompanhamento. Sumarizando, infere-se que, quanto à permanência total do selante, os resultados descritos para o selante, "Delton" foram de 95,0\%, $84,0 \%, 80,0 \%, 72,0 \%$ e $68 \%$, e no selante "Nuva Seal", foram de 88,0\%, $58,0 \%, 60,0 \%, 35,0 \%$ e 37,0\%, respectivamente após 1,2,3,4,5 e 6 anos,

Quanto à eficácia na prevenção de cáries oclusais, os dados relatados são $71,0 \%, 69,0 \%, 62,0 \%$ e 55,0\%, respectivamente após 2,3,4,5 e 6 anos, com o selante "Delton", e de 38,0\%, 39,0\%, 14,0\% e 8,0\%, após os mesmos períodos de tempo com o selante "Nuva Seal".

Para GWINNETT ${ }^{144}$, em 1982, o sucesso do tratamento com selantes depende diretamente da técnica, da habilidade do profissional e também da cooperação do paciente. Cada passo é crítico para o sucesso do tratamento; o profissional deve estar familiarizado com os procedimentos operatórios e com as propriedades inerentes de cada material a ser utilizado.

Na Conferência "Selantes dentais na prevenção de cáries dentárias" realizada pela American Dental Association ${ }^{5}$, em 1983, a literatura e os dados 
sobre selantes de fossas e fissuras foram revisados mostrando a segurança e a eficácia desta técnica, levando a uma grande campanha a favor da utilização de selantes pela A.D.A. Numa publicação, resultante desta conferência, referem-se alguns aspectos importantes relativos ao uso dos selantes. Assim, os selantes estão indicados para crianças e adultos que, por qualquer razão, são de risco moderado ou alto para a cárie; que tem cáries incipientes (cáries do esmalte) ao nível de fossas e fissuras; que tem fossas e fissuras que, pelas suas características anatômicas são susceptíveis à cárie; que tem os dentes suficientemente irrompidos e com fossas e fissuras susceptíveis. Obviamente que a decisão do selar ou não, pertence ao dentista mas o seu julgamento deve ser feito em relação a um dente específico e numa altura própria.

De acordo com STAMM ${ }^{318}$, em 1983, o maior objetivo da prática da Odontologia é a prevenção das doenças nos orgãos bucais. Sendo assim selantes não são uma alternativa aos materiais restauradores. Eles representam uma alternativa com altíssima eficácia e um procedimento técnico que se for corretamente utilizado num programa preventivo poderá significantemente reduzir o desgaste da estrutura dental e posterior restauração. Isto é um motivo relevante para a utilização dos selantes na prática da odontologia privada. Os selantes oclusais são os mais importantes e eficazes materiais que o Cirurgião-Dentista poderá fazer uso na prevenção da cárie de cicatrículas, fossas e fissuras.

MAIN et $a^{211}$., em 1983, realizaram três estudos laboratoriais objetivando a redução do tempo de tratamento das superfícies oclusais do esmalte para o selamento de fissuras. O estudo I avaliou o efeito da redução do tempo do condicionamento ácido de 60 segundos para 10 segundos na resistência de união do selante. O estudo II avaliou a efetividade de remoção da película adquirida pelo condicionamento ácido e o III a efetividade da limpeza final do esmalte pelo ar comprimido comparado com agentes químicos secos. Os resultados do estudo I mostraram que 10 segundos de condicionamento ácido produzem um padrão condicionado mais brando que 60 segundos. Isto pode resultar em prolongamentos retentivos mais curtos e finos, embora não reduza a resistência mecânica de permanência do selante a curto prazo. O estudo II comprovou que sob condições laboratoriais ou "in vivo", a 
película adquirida é completamente removida por um condicionamento ácido padrão. Este indicou a profilaxia das fissuras antes do condicionamento ácido não é necessária. O estudo III comprovou que o ar comprimido secou 0 esmalte mais rapidamente e em maior grau que os agentes químicos de secagem.

SWANGO; BRUNELLE ${ }^{336}$, 1983, em um estudo epidemiológico envolvendo 38.000 crianças demonstraram que as áreas de maior suscetibilidade são as superfícies oclusais dos primeiros e segundos molares permanentes.

MERTZ-FAIRHURST ${ }^{228}$, em 1984, observou, como vantagem de um selante fotopolimerizável, o fato de dispensar o processo de mistura entre base e catalizador, diminuindo, desta maneira, a incorporação da bolhas de ar no material selador.

Segundo SIMONSEN ${ }^{309}$ (1984), para decidir em que casos usar o selante, o profissional deve usar o julgamento clínico na seleção de dentes que sejam mais prováveis de virem a adquirir a cárie, tendo como base a idade e higiene oral do paciente, histórico familiar e individual de cárie dentária, o ambiente e histórico com fluoretos, hábitos dietéticos, tipo e morfologia dentária.

Há controvérsias em relação ao tempo de permanência dos selantes. Uma corrente afirma que uma vez que o selante foi aplicado, deverá ser mantido pelo resto da vida, ao dente. Além disso, se o selante se deslocar a atividade cariogênica terá início. Entretanto há uma outra corrente que acredita que quando o indivíduo atingir a maioridade, a atividade cariogênica decrescerá em razão de modificações na dieta e na química do organismo, sugerindo, portanto, que a aplicação do selante só deverá ser feita durante os anos em que exista uma maior tendência a cárie (KEMPER ${ }^{181}$, 1984).

MENAKER ${ }^{224}$, em 1984, ao fazer considerações sobre a relação entre as propriedades físicas dos selantes e sua capacidade de ligação com 0 esmalte,afirma que a ligação eficiente do selante depende da ancoragem 
mecânica microscópica e da atração eletrostática entre o selante e o esmalte atacado. Os fatores que contribuem para uma boa resistência tênsil do selante e a capacidade do mesmo em escoamento, penetrando na superfície áspera. Selantes que mostram maior penetração no esmalte tem baixos ângulos de contato e baixa viscosidade.

Ângulo de contato é a medida da capacidade de um líquido em escoar sobre uma dada superfície. Especificamente, ângulo de contato é aquele formado entre a superfície de um líquido e uma dada superfície, naquele ponto onde o líquido contata essa superfície. As diferenças de ângulo de contato podem ser visualizadas comparando-se uma gota de água sobre uma superfície encerada e outra não encerada. Num selante, um baixo ângulo de contato com o esmalte atacado indica que o selante escoará sobre a superfície, fluindo para as microporosidades criadas pelo ataque ácido e propiciando um contato íntimo para uma boa ligação.

A viscosidade do selante também desempenha papel na ligação. Um selante com baixa viscosidade fluirá mais prontamente pela superfície atacada e para dentro das fissuras do esmalte. Uma combinação de baixa viscosidade e baixo ângulo de contato dará ao selante as características necessárias para que se espraie sobre a superfície e para dentro das microporosidades do esmalte atacado, formando longas projeções de selante para uma forte ligação.

A maioria dos selantes está baseada no BIS-GMA ou metacrilatos de semelhante alto peso molecular. O BIS-GMA, por si só, possui a viscosidade de mel frio e, dessa maneira, não fluiria suficientemente nas fissuras e esmalte atacado, para prover um bom selamento. Assim, monômeros diluentes mais fluidos são acrescentados, reduzindo a viscosidade do BISGMA e melhorando as características de fluxo e capacidade de escoamento do selante. Monômeros fluidos típicos incluem os derivados do glicol tal como o dimetacrilato de trietilenoglicol e o material mais básico, metil metacrilato.

Muitos dos selantes de cicatrículas, fossas e fissuras são resinas sem a fase inorgânica (isto é, sem partículas de carga), que é acrescentada para a redução do desgaste. A inclusão da fase inorgânica obriga, no entanto, a um passo extra na técnica de inserção para o ajuste da oclusão depois da colocação do selante. 
Afirma ainda MENAKER ${ }^{224}$, em 1984, que a microinfiltração nos selantes está diretamente ligada à capacidade de ligação do material. Com uma boa penetração do selante no esmalte atacado e uma forte e duradoura ligação, a microinfiltração será praticamente inexistente. Enquanto a ligação permanecer intacta, qualquer infiltração teria que progredir por vales e montanhas, num progresso tortuoso, pela interface selante/esmalte. A microinfiltração não ocorre, em nenhum grau mensurável, quando existe uma boa ligação e adaptação do selante. Se, por outro lado, a permanência do selante é pobre, devido a qualquer número de fatores, inclusive características limitadas da capacidade de escoamento, ataque ácido imperfeito, contaminação da superfície atacada do esmalte ou fratura do selante, alguma infiltração passará a ocorrer.

BOHANNAN $^{30}$, em 1984, baseado em estudos epidemiológicos, realizados em 1935 e 1940, afirmou que 50\% das lesões cariosas encontradas em crianças de 6 a 14 anos localizam-se nas faces oclusais, e propõe o uso de selante como meio de prevenção de cáries nesta região. Ele afirmou que não se deve temer o selamento inadvertido em superfícies cariadas, pois estas não progridem quando seladas e as bactérias recobertas por um selante íntegro não sobrevivem, devendo os cirurgiões-dentistas começarem a considerar o uso de selantes como um método alternativo para o tratamento de pequenas lesões cariosas.

Selamentos podem ser considerados um procedimento clínico não de vida curta. A longevidade pode ser comparada com a das restaurações convencionais de amálgama (MERTZ-FAIRHURST ${ }^{228}$, 1984).

A literatura indica que permanência de selantes está na dependência de vários fatores (HINDING ${ }^{159}$, 1974; STRAFFON ${ }^{325}$ et al., 1985) incluindo tipo de dente, método de aplicação do selante e tipo de polimerização.

A terapia com selantes parece inibir o avanço do processo carioso. Se o selante é perdido, é melhor reatacar a superfície e reaplicar o selante ao dente. Esta terapia deve ser o tratamento de escolha para lesões cariosas recém formadas nas áreas de fissuras 
O conceito preventivo em odontologia deve ser uma filosofia praticada em todos os níveis de atuação da profissão. Este conceito cria em situação de manutenção periódica o bom relacionamento entre dentista e paciente. Terapia com selantes direcionada a todos os níveis de população poderia contribuir para a extensão deste relacionamento.

RIPA $^{271}$, em 1985, ao realizar uma revisão sobre as indicações da técnica de selamento de fossas, cicatrículas e fissuras disse:

1- o declínio de cárie não tem sido uniforme para todas as superfícies dentais.

2- a distribuição de cáries em diferentes superfícies oclusais tem mudado, resultando num aumento da porcentagem de cáries em fossas, cicatrículas e fissuras.

3- a porcentagem de distribuição de cáries por superfície dentária é similar em áreas com fluoretação da água de abastecimento em situação ideal com aquelas em áreas com a fluoretação deficiente.

4- O número de experiências de cárie em crianças tem se mantido alto, a despeito do declínio do número de lesões cariosas.

Esta afirmação de RIPA ${ }^{273}$, datada de 1985, tem muita semelhança àquela verificada hoje sobre as condições dentais da população mundial de uma maneira geral.

RIPA; LESKE; FORTE ${ }^{274}$, em 1986, realizaram estudo para determinar os benefícios da combinação entre a utilização do selante resinoso Delton, autopolimerizável, e bochechos semanais com soluções fluoretadas de $\mathrm{NaF}$ a $0,2 \%$. Constataram que os benefícios das duas técnicas somaram-se no sentido de prevenir o desenvolvimento de novas lesões cariosas. A terapia com flúor, que protege especialmente as superfícies dentárias lisas, e o selamento das superfícies oclusais, que é proteção específica para as áreas de cicatrículas e fissuras, podem quando associados eliminar quase que totalmente a incidência de novas lesões cariosas em um população escolar infantil. O selante age como uma barreira física, prevenindo a criação de condições ácidas pela bactéria bucal e seu substrato, que resultam em cárie. 
$\mathrm{VRBIC}^{363}$ em 1986, continuando avaliação de trabalho de $\mathrm{VRBIC}^{362}$, em 1983, avalia clinicamente a permanência de selantes num período de 5 anos na Eslovenia, num grupo de 290 crianças que tiveram um par contralateral de dentes molares permanentes selecionados, sendo que um deles foi selado e o outro do lado oposto foi mantido sem selante como controle; foram selados 115 molares decíduos e 373 primeiros molares permanentes. O selante Contact Seal (autopolimerizável) foi aplicado de acordo com instruções do fabricante, após condicionamento da superfície de esmalte com ácido ortofosfórico, e com o melhor controle possível de exposição a umidade durante a aplicação. A permanência completa do selante foi $93 \%$ após um ano, $86 \%$ após dois anos, $67 \%$ após 3 anos, $61 \%$ após quatro anos e 52\% após cinco anos. $A$ incidência de cáries em fissuras foi significantemente maior $(p<.001)$ nos dentes controle, não selados, do que naqueles selados. A redução de cáries observada após cinco anos de aplicação do selante foi de 55\%. $\mathrm{VRBIC}^{363}$, 1986, terminou afirmando que o selamento é uma técnica adequada, indicada para molares permanentes logo após sua erupção, e que essa técnica seria menos danosa ao dente do que um preparo cavitário, realizado com a orientação de confecção da cavidade com extensão preventiva.

Estas observações vêm de encontro aos trabalhos de MERTZFAIRHURST et $\mathrm{al}^{228}$., 1984, que observaram após sete anos de vida útil a permanência completa do selante em $66 \%$ dos dentes, implicando numa efetividade de 55\% na redução de cárie, e de SIMONSEN ${ }^{313}, 1990$, que em dez anos de observação, encontrou permanência total em 56,7\% das superfícies, sendo que em apenas $6,9 \%$ dos casos de selante estava ausente. Observações por períodos maiores, como 15 anos após a aplicação do selante, permitem verificar uma menor porcentagem de selantes completamente retidos $(35,4 \%)$, no entanto, os dentes que receberam selamento apresentavam-se sadios em $74 \%$ dos casos, SIMONSEM ${ }^{295}, 1991$.

RAADAL et al ${ }^{259}$., em 1984, compararam o benefício alcançado entre a aplicação com verniz de flúor e o selante para controle de cárie oclusal em criança de 6 anos com baixa prevalência de cárie. As crianças tiveram os primeiros molares permanentes de um hemiarco selados es molares do outro hemiarco tratados com verniz. 
O selamento das superfícies oclusais foi realizado no início do experimento e a aplicação do verniz era feita de 6 meses durante um período de 2 anos. Os resultados mostraram que 63\% das crianças eram livres de cárie, ao passo que 15\% tinham lesões de cárie nos dois hemiarcos. Entre os dentes selados, $62 \%$ estavam intactos após dois anos.

Um dos motivos para a pouca utilização de selantes de fossa e fissuras pelos C.D. é a falta de segurança destes, em relação a esta utilização, a questão de estarem ou não aplicando corretamente e/ou apropriadamente estes selantes. (Council on Dental Research7: Cost-effectiveness of sealants in private practice and standards for use in prepaid dental care, 1985).

HARDISON et al ${ }^{152}$, em 1987, consideraram a baixa viscosidade como uma característica desejável para os selantes de fossas e fissuras. Sem dúvida alguma esta propriedade fornecerá ao material uma capacidade maior de escoamento na superfície oclusal e penetração no esmalte dental; por outro lado quando o material é aplicado com o paciente em posição reclinada poderá ocorrer uma distribuição não uniforme do selante nos sulcos, fossas e fissuras, em decorrência do acúmulo do material na porção distal da superfície oclusal. Isto possivelmente seria reduzido com a aplicação de um selante com o paciente em posição mais adequada.

TAVARES et al ${ }^{341}$., em 1987, testaram o grau de permanência de um selante de fossas e fissuras quando é feito o uso de flúor antes ou depois da aplicação do selante, e sem esta associação. Foram selados 144 primeiros molares permanentes hígidos em 42 crianças de 5 a 10 anos de idade, alunos do Colégio de Aplicação da Universidade Federal de Santa Catarina, distribuídas em 3 grupos: I e II, cujos dentes foram selados e receberam respectivamente, uma aplicação tópica de flúor fosfato ácido, antes e após os procedimentos de aplicação do selante e III, cujos dentes não receberam aplicação tópica de flúor (Grupo Controle). Concluiu-se que o grau de permanência do selante oclusal não difere estatisticamente nas 3 condições, havendo, no entanto, uma tendência para melhor grau de permanência do selante oclusal quando a aplicação tópica de flúor era realizada após o selante ou quando não era realizada a aplicação de flúor. Entretanto, há um tendência para melhor grau de permanência do selante 
oclusal quando a aplicação do selante é associada a uma exposição posterior ou quando não há exposição ao flúor tópico (Grupos II e III), do que uma exposição prévia ao flúor tópico (Grupo I). Desta forma, quando a aplicação do selante oclusal for acompanhada de uma aplicação tópica de flúor, TAVARES et $\mathrm{al}^{341}$., 1987, recomendaram que esta seja feita posteriormente ao selamento oclusal.

DUARTE; ISSAO ${ }^{100}$, em 1987, apresentaram resultados de um trabalho desenvolvido com um grupo de 40 crianças na faixa etária de 5 anos e meio a 6 anos e meio, onde foram aplicados selantes em 90 primeiros molares permanentes sendo que em 45 foi também aplicado o fluoreto de sódio acidulado. Após 4 e 8 meses de acompanhamento, certificaram-se que a permanência do selante é melhor nos inferiores que nos superiores e que, na porção distal a perda do selante ocorre com maior freqüência. A associação selante e aplicação tópica de solução fluoretada além de aumentar o grau de permanência do selante, determina uma diminuição de cáries nas superfícies lisas, indicando uma boa combinação num programa de prevenção de cáries dentárias.

CURRO; MAINE ${ }^{80}$, em 1987, colocaram que tem sido demonstrado que superfícies oclusais de molares e pré-molares, lingual, fossas palatinas de molares e incisivos superiores e fossas vestibulares de molar inferior são particularmente suscetíveis ao ataque de cárie. Portanto os objetivos clínicos e a técnica de selamento podem ser aplicadas com consistência, independente da idade do paciente. Para CURRO; MAINE ${ }^{80}$, cada vez mais a população adulta tem sido tratada para condições sistêmicas com um longo regime de drogas. Adicionalmente os indivíduos estão vivendo mais, com aumento da vida produtiva. As drogas freqüentemente apresentam efeitos colaterais, entre eles as glândulas salivares podem ter sua secreção diminuída. Esta condição pode possibilitar aumento da susceptibilidade à cárie, expondo fossas e fissuras em adultos. Crianças não tem monopólio em cáries oclusais. O clínico não pode prever qual dente vai cariar. Na opinião deles, a terapia com selantes pode ser tratamento de escolha para todas as idades, para cáries incipientes, em substituição à restaurações conservativas com amálgama à odontotomia profilática ou à filosofia "ver e esperar". 
Em 1988 RIPA; LESKE; VARMA ${ }^{275}$, reafirmaram que embora a prevalência de cárie nas superfícies proximais tenha diminuído substancialmente nos países desenvolvidos, o comportamento das regiões de sulcos tem se mantido inalterado em torno de $80 \%$ nos últimos 20 anos.

O agente condicionador ácido fosfórico, apresenta-se sob a forma de solução ou gel, BROWN et $\mathrm{al}^{46}$., em 1988, sugeriram que tanto a solução quanto o gel, são igualmente efetivos para serem utilizados. Ambas as formas, produzem um padrão de condicionamento similar, e nenhuma delas é eficiente na remoção de depósitos e películas no fundo dos sulcos, das fóssulas e das fissuras mais profundas. O uso do gel, apresenta como vantagem clínica, a facilidade em controlar a colocação do ácido, durante à aplicação.

VERTUAN; BARELLI; SERRA ${ }^{358}$, em 1988, colocaram que à vista dos elevados índices de cárie, programas preventivos tem sido desenvolvidos, no intuito de se evitar o aparecimento e o incremento da ocorrência do problema cárie dental. Entre os vários recursos que a Odontologia Preventiva tem às mãos, está o emprego de selantes de fossas e fissuras oclusais, que proporciona excelentes resultados, visto que este material, à base de resina sintética fluida, cria uma barreira física contra os microorganismos e seus substratos. Estes autores realizaram estudo em esmaltes de $3^{\text {os }}$. molares inclusos ou semiinclusos, verificando os efeitos da contaminação salivar por diferentes tempos, logo após o ataque ácido. Observaram sob microscópio eletrônico de varredura que a contaminação por 30 ou 5 segundos deixa resíduos que dificultariam a penetração de resina oclusal. A lavagem e a secagem por 30 segundos não conseguiu remover resíduos deixados pela saliva, portanto qualquer procedimento onde se utilize $o$ ataque ácido em esmalte como meio retentivo deve ser realizado ao isolamento absoluto.

Em 1988, DONNAN; BALL ${ }^{87}$, realizaram um estudo clínico com o fim de estabelecer se a profilaxia do esmalte prévia ao condicionamento ácido era necessária para promover adequada permanência do selante de fissura. Para isto, 278 dentes de 59 pacientes entre sete e dezesseis anos foram divididos 
ao acaso em dois grupos, com 175 sítios de fossas e fissuras para cada grupo. No grupo 1, nenhuma profilaxia precedeu o condicionamento ácido e no grupo 2, as superfícies oclusais foram limpas com taça de borracha e pedra-pomes antes do condicionamento. O selamento foi feito com uma resina Bis-GMA fotopolimerizável e de baixa viscosidade (Helioseal). A permanência do selante para os dois grupos foi comparada aos seis e doze meses. Os resultados não mostraram diferenças estatisticamente significantes nos índices de permanência entre os grupos. A razão para se recomendar a profilaxia prévia ao condicionamento seria a remoção de placa e película, que poderiam, teoricamente, interferir com o processo de condicionamento. A discussão indicou que esta remoção seria pouco provável de se fazer em áreas importantes para união do selante e que o condicionamento ácido tem sido efetivo, apesar da presença da placa e película. Se o condicionamento ácido isoladamente falhasse em criar um padrão condicionado ou deixasse placa residual ou película na superfície dentária, poderia haver interferência na união, levando a uma falha precoce de selante. Não encontraram diferenças estatisticamente significante, entre os dentes que receberam e os que não receberam profilaxia dental, com pasta de pedra pomes antes do condicionamento ácido do esmalte. Concluíram que a profilaxia dental possa ser desprezada, uma vez que não contribui diretamente para a permanência do selante, resultando em menor tempo de trabalho e eventualmente trazendo menos desconforto ao paciente.

Em 1988 MOORE; JACKSON ${ }^{235}$, propuseram um artigo objetivando revisar a efetividade dos selantes de fissuras e como, onde, e quando usálos, com o fim de motivar todos os profissionais de saúde dental a adotá-los na sua prática clínica. A efetividade dos selantes se aproxima muito da sua permanência. Vários fatores colaboram para a permanência do material como a técnica de aplicação, tipo de material selador e a morfologia da superfície dentária à qual foi aplicado. Os primeiros selantes eram polimerizados por luz ultravioleta, apresentando índices de permanência variando de 40-82\% após um ano e 10-40\% após cinco anos. Estudos mais recentes utilizando selantes autopolimerizáveis e fotopolimerizáveis têm demonstrado altos níveis de permanência, com uma redução de cáries de 90-95\% após um ano e de pelo menos $50 \%$ após seis anos. Muitos profissionais 
ainda são relutantes em usá-los, temendo o selamento de cáries incipientes. Estudos demonstraram que o selamento proposital de cáries envolvendo somente a superfície oclusal, permitem a paralisação destas e a maioria das lesões tornam-se estéreis. Alguns autores concluíram que se o selante for perdido, o dente não se torna mais cárie-suscetíveis como antes da aplicação do material. Isto provavelmente ocorrerá porque os prolongamentos resinosos se mantêm embricados no esmalte. A perda do selante geralmente ocorre entre seis e doze meses após sua aplicação. Acredita-se que a maior causa se dê por falhas na técnica, comumente associada à contaminação salivar da superfície condicionada. A decisão selar ou não as superfícies deve ser tomada para cada paciente e em base de dentes individuais. Além disso, o paciente deve receber os benefícios do flúor como também estar integrado num programa de controles periódicos dos selantes, viabilizando um tratamento completo.

Posteriormente em 1989 BOTAZZO; MANFREDINI; NARVAI ${ }^{33}$, analisaram o Programa Nacional de controle da cárie dental com o uso de selantes e flúor proposto pelo Departamento de Odontologia do INAMPS, onde discutiram sobre os selantes oclusais, como uma das medidas preventivas de utilização em sistemas de prevenção da cárie dental, e o significado do seu uso em campanhas de saúde pública, de abrangência nacional.

SIMONSEN ${ }^{312}$, em 1989, indicou critérios para o selamento de fossas, cicatrículas e fissuras, afirmando que como qualquer técnica operatória o selamento não é indicado para todo e qualquer dente posterior livre de cárie. Para decidir quando deve o dente ser selado o cirurgião-dentista pode seguir uma triagem separando em três grupos o paciente em questão quando ele entrar em faixas etárias que disse serem apropriadas.

Os três grupos de pacientes são:

Grupo 1 - pacientes nos quais os dentes não estão cariados e que provavelmente não terão lesão cariosa.

Grupo 2 - pacientes nos quais os dentes apesar de se apresentarem com sinais de livres de cárie, irão provavelmente apresentar lesão cariosa se não selados.

Grupo 3 - pacientes com cáries rampantes que irão desenvolver lesões interproximais tão rapidamente quanto lesões oclusais. 
Dentre estes 3 grupos de pacientes SIMONSEN ${ }^{312}$ (1989) indicou o selamento para aqueles que se apresentem com características dentro do grupo 2.

Para SIMONSEN ${ }^{312}$ (1989) as faixas etárias onde a aplicação de selante seriam apropriadamente indicadas dos 3 aos 4 anos de idade para os molares decíduos, dos 6 aos 7 anos para os $1^{\text {os }}$ molares permanentes e dos 11 aos 13 para $2^{\text {os }}$ molares permanentes.

Nestas faixas etárias seria apropriado sempre avaliar a necessidade ou não de selamento para cada paciente individualmente.

Sem nenhum teste para predisposição à cárie realizado a solução mais realista para decidir que provável usar na seleção de pacientes para aplicação ou não de selantes é simplesmente usar o julgamento clínico profissional para selecionar aqueles dentes que mais parecem poder apresentar cárie.

Esta decisão deveria se basear em :

- idade do paciente

- higiene oral do paciente

- história familiar de cárie

- história individual de cárie

- história de exposição à fluoretos

- hábitos de dieta

- confiança no paciente quanto as consultas de retornos periódicos

- morfologia dentária

testes adicionais salivares para avaliação de fluxo e níveis de Streptococcus mutans podem também ser considerados.

Ele diz também que permitir que o grupo 2 tenha abrangência sobre grupos 1 e 3 pode minimizar erros de julgamento e ocorrência de lesões cariosas passíveis de prevenção.

Os dentes com maior suscetibilidade à cárie e portanto aqueles que mais são beneficiados com o selamento parecem ser os primeiros e os segundos molares permanentes.

Selantes podem ser colocados em qualquer dente livre de cárie e suscetível à cárie. Adicionalmente, disse, selante pode ser colocado naqueles dentes que se julga com possibilidade de cariar e até naqueles que se julga provavelmente cariados. 
SIMONSEN ${ }^{312}$ afirmou ainda em 1989: "quando em dúvida sele". Ele acredita que está ocorrendo uma queda na experiência de cárie em pacientes entre 5 a 17 anos de idade, mas pensa que este declínio é maior nas superfícies lisas que nas áreas das fossas e fissuras. Afirmou que preferiria ver suas crianças com selamento do que esperar e ver se dentes irão ou não apresentar cárie.

SIMONSEN ${ }^{311}$ em outro trabalho no mesmo ano, colocou que selamento indubitavelmente tem seu espaço no arsenal da clínica odontológica preventiva. Quando usado combinado com o uso efetivo de flúor, a combinação pode prevenir cárie inteiramente em muitas crianças, benefícios adicionais intangíveis da aplicação de selantes são ausência de dor, maior aceitação estética, menor tempo de trabalho clínico e o benefício fisiológico de manter a dentição intacta. $O$ custo de aplicar selantes nos $1^{\circ}$ molares permanentes em 1 grupo de crianças e reaplicá-lo em todas as áreas que perderam o selante num período de 10 anos foi $2 / 3$ do custo de tratamento das lesões cariosas que ocorreram em 1 grupo de crianças que não receberam selamento neste mesmo período de 10 anos.

DIN; VERTUAN; MENDES ${ }^{94}, 1989$, apresentaram um estudo clínico realizado para avaliar a permanência de um tipo de selante autopolimerizável, Delton (Johnson \& Johnson), em superfícies oclusais de prémolares e $1^{\circ}$ s molares permanentes de escolares de $1^{\circ}$ grau, com idade entre 6 e 9 anos. A permanência completa de selante em superfícies de prémolares foi de $95,6 \%$ e 62,2\% após 6 e 12 meses, respectivamente, não se apresentando significante a diferença desta permanência entre pré-molares superiores e inferiores em nenhuma das observações realizadas. Para superfícies de $1^{\circ}$. molares permanentes foi observada completa permanência de $92,8 \%$ e 87,0\% respectivamente após 6 e 12 meses. Apresentou-se esta permanência com diferença, significante entre $1^{\circ}$ molares superiores $\mathrm{e}$ inferiores em ambas observações.

PRADO; GARONE NETTO ${ }^{256}$, em 1990, estudaram o grau de permanência do selante Delton em molares decíduos e permanentes em crianças de 2 a 8 anos de idade durante 18 meses. Verificaram no decorrer do respectivo estudo que o maior número de perdas do selante, ocorreu na 
fossa disto. oclusal dos $1^{\circ}$ molares permanentes superiores e a maior permanência nos dentes inferiores. Os dentes que se mantiveram total ou parcialmente selados não apresentaram cárie durante o referido período, sendo considerado este, um método válido na prevenção de cáries oclusais em dentes decíduos em crianças nessa faixa etária.

ROMCKE et al ${ }^{290}$., em 1990, mostraram em seu trabalho, de avaliação da permanência e manutenção de selantes num período de 10 anos, um sucesso de $84,9 \%$.

DENNINSON; STRAFFON; MORE ${ }^{90}$, em 1990, verificaram que a aplicação clínica de selante autopolimerizável foi mantida com apropriado retratamento quando selante foi perdido, fissuras foram expostas ou fendas marginais observadas. Foram tratadas 100 superfícies oclusais. Avaliadas 75 superfícies após 36 meses destas, 52 superfícies (69,3\%) requereram retratamento no período de 36 meses. Colocaram ainda que, dentes com estágio de irupção menos avançados requereram mais retratamento que aqueles com estágios iruptivos avançados.

MITCHEL; MURRAY'233, em 1990, avaliaram um trabalho de 1987, por eles realizado onde estudaram a longevidade dos selantes e acharam que após 66 meses de selamento, de 3017 dentes foram detectados clinicamente 93 dentes com cáries oclusais e 26 com proximais. Em 1990 avaliaram porque ocorreram lesões cariosas nos dentes selados no trabalho de 1987, e viram que poucos dentes apresentam cárie $(3,1 \%)$, e que eles pertenciam a indivíduos que necessitavam de maior controle periódico, com acompanhamento dietético e uso de flúor tópico. Estes pacientes são aqueles que pertencem a grupo de risco.

MEJARE; MJOR ${ }^{223}$, em 1990, num estudo clínico de 5 anos com selantes, avaliaram de quatro maneiras a performance dos selantes: extensão do selamento, adaptação ao esmalte, topografia oclusal e capacidade de prevenir cáries. O trabalho verificou para o selante de resina, de 6 a 12\% de perda completa do selante, porém, quando a perda é parcial ela se dá da periferia para o centro. $97 \%$ demostraram boa adaptação ao esmalte, $48 \%$ continuavam cobrindo toda extensão oclusal e, cáries foram encontrados em 
$5 \%$ dos dentes selados. Para selante ionomérico verificaram: grande perda, $61 \%$ entre 6 e 12 meses e $91 \%$ entre 30 e 36 meses, e perda total em $7 \%$. A topografia oclusal pode ser um obstáculo para uma boa adesão, 25\% demonstraram aceitável adaptação e nenhuma cárie foi observada mesmo em dentes onde o selante era dado como perdido clinicamente. Nesses casos o ionômero encontrava-se retido nas cicatrículas e fissuras centrais. Esses autores utilizaram-se de 208 dentes, molares permanentes e pré molares, de 62 crianças, com idade entre 7 e 10 anos para comparar a permanência de dois selantes resinosos (Delton, Concise), com um cimento de ionômero de vidro (Fuji III). Por um período de 6 meses a 5 anos, onde observaram clinicamente que, embora $84 \%$ de selantes ionoméricos foram julgados perdidos, porém a avaliação microscópica de réplicas dentárias, mostrou algum selante retido na profundidade das fissuras de $93 \%$ dos dentes. Os selantes resinosos apresentaram permanência completa em $90 \%$ dos casos.

No trabalho de COOLEY et $\mathrm{al}^{77}$., em 1990, o selante contendo flúor Fluroshield, foi avaliado "in vitro" e comparado com o selante sem flúor HelioSeal. Os dois materiais foram aplicados às superfícies oclusais de dentes extraídos e microscopicamente avaliados por sua habilidade de penetrar nas cicatrículas e fissuras. Outras amostras foram imersas em solução corante e avaliadas quanto a à ocorrência de microinfiltração. Amostras de discos fatiados do selante Fluroshield foram imersas em água e analisadas por sete dias quanto à liberação de flúor. Não houve diferenças estatísticas entre o Fluroshield e o HelioSeal quanto à penetração nas fissuras. O Fluroshield permitiu microinfiltração em sete dos espécimes testados, enquanto que o HelioSeal não infiltrou. Uma possível explicação se dê pela maior viscosidade deste material, que pareceu não escoar tão bem dentro das fissuras. Talvez esta microinfiltração não seja clinicamente significante, considerando a habilidade do selante em liberar flúor, protegendo o esmalte até $60 \mu \mathrm{m}$ de profundidade. Todos os espécimes do Fluroshield liberaram flúor ao longo dos sete dias testados. Houve um "efeito explosão" no qual grandes quantias de flúor foram liberadas no primeiro e segundo dia, diminuindo as concentrações de flúor aproximadamente pela metade nos dias subsequentes. 
ROCK; WEATHERIL; ANDERSON ${ }^{286}$, em 1990, num estudo "in vivo" reportaram os resultados de três anos, comparando três selantes diferentes (dois fotopolimerizáveis e um quimicamente polimerizável), em relação ao método de polimerização e conteúdo de carga do material, usando como controle os dentes do lado oposto do arco. Outra variável incluída no estudo foi a avaliação do ácido fosfórico em forma de gel ou líquido para condicionamento do esmalte. Um total de 744 primeiros molares permanentes foram selados em crianças entre seis e sete anos, no início do estudo. As resinas utilizadas foram o Delton autopolimerizável, Delton fotopolimerizável e o Prismashield (com carga). Retornos periódicos foram realizados após seis meses e anualmente durante três anos. Ao final deste período, as resinas permaneceram completamente retidas em $77 \%$ dos dentes. A permanência do selante fotopolimerizável sem carga foi significantemente melhor que a resina fotopolimerizável com carga. Não houve diferenças significantes entre as resinas foto com carga e quimicamente polimerizável com relação à permanência. $O$ uso do condicionador em forma de gel foi tão efetivo quanto em líquido.

OVREBO; RAADAL ${ }^{245}$, em 1990, utilizaram microscopia ótica comparando microinfiltração em fissuras seladas com resina e com cimento ionomérico. Esses autores encontraram que dentes selados com cimento ionomérico demonstravam infiltração tanto na interface dente/cimento, quanto através do cimento ionomérico. Observaram que em fissuras onde o cimento ionomérico era dado como clinicamente perdido havia remanescente do selante dentro da fissura, o que é ainda um reservatório de flúor mesmo em casos onde é dado como clinicamente perdido. No selante de resina não havia infiltração em $93 \%$ dos dentes selados, e em $7 \%$ havia infiltração superficial.

A prevenção de cárie em $100 \%$ dos dentes selados foi conseguida por MEJARE; MJOR ${ }^{223}, 1990$, após estudo de 5 anos, onde compararam o comportamento clínico de dois selantes resinosos, Concise e Delton.

Sabe-se que mais de $60 \%$ do número total de restaurações, na idade de 13-15 anos, são oclusais embora essas superfícies constituam apenas 12,5\% das superfícies dentárias da boca (SIMONSEN $\left.{ }^{315}, 1991\right)$. As cáries ocorrem cedo, de forma geral dois anos após o irrompimento dos dentes $80 \%$ tem 
cárie na oclusal. Assim, verifica-se que o selamento de áreas de cicatrículas e fissuras constitui-se num método eficiente no controle de lesões cariosas, podendo nos períodos críticos, ou seja, nas primeiras décadas de vida, bloquear áreas suscetíveis e predisponentes à propagação da lesão.

SIMONSEN ${ }^{315}$, em 1991, em estudo de 15 anos com selantes, encontrou um percentual de permanência total de $27,6 \%$, e permanência parcial de $35,4 \%$, e perda total de $10 \%$. Observou também $26 \%$ de superfícies cariadas ou restauradas. Os dentes apresentavam-se livres de cáries em $94 \%$ com 5 anos de estudo, $84 \%$ com 10 anos e $74 \%$ com 15 anos. O estudo refletiu a performance de um material aplicado por um operador treinado, sem isolamento absoluto e que em 15 minutos selava os 4 primeiros molares. $O$ estudo concluiu que o selamento é significantemente benéfico, já que reduz tratamentos custosos, causa pouco trauma na criança e ao longo do tempo poucas restaurações são colocadas e recolocadas. O estudo sugeriu que em condições especiais a prática do selamento poderia prevenir $100 \%$ de cáries em fossas, cicatrículas e fissuras.

CASTRO $^{66}$ et al., em 1991, analisaram através da microscopia ótica comum, a penetração de selante de fossas, cicatrículas e fissuras no esmalte dental humano condicionado, contaminado ou não, pela umidade bucal ou saliva. Verificaram que os selantes Delton, Oralin e Helioral apresentaram um mesmo nível de penetração no esmalte dental e superior ao selante PrismaShield; o selante dental, sobre esmalte condicionado não contaminado, mostrou-se superior quanto à penetração, durante o selamento oclusal.

TRUHE ${ }^{350}$, em 1991, disse que estudos por 15 anos provam a segurança e efetividade do selamento, que é especialmente benéfico nas superfícies oclusais, aumentando a probabilidade de que as crianças entrem na idade adulta livres de cáries.

PRADO ${ }^{255}$, em 1991, no seu trabalho de dissertação de tese de doutorado, estudou comparativamente a permanência do selante Delton e do Fuji III e a eficiência na prevenção de cáries oclusais em segundos molares decíduos e primeiros molares permanentes de crianças de 5 a 8 anos 
de idade. A avaliação de permanência e prevenção de cáries foi realizada de 6 em 6 meses, durante 18 meses, obtendo um maior grau de permanência nos molares permanentes e decíduos tratados com Delton. Ambos os materiais se mostraram efetivos na prevenção de cárie oclusal.

Em 1991 CARVALHO; EKSTRAND; THYLSTRUP'2 , e em 1992 CARVALHO; THYLSTRUP; EKSTRAND ${ }^{64}$, conduziram estudos sobre 0 tratamento não restaurador da cárie oclusal em crianças dinamarquesas de 6-8 anos de idade. O tratamento foi baseado em instrução dos pais e de seus filhos, controle profissional da placa e aplicação tópica de flúor de acordo com a necessidade individual. $\mathrm{O}$ controle profissional da placa era feito em toda dentição, mas flúor tópico era somente aplicado sobre superfícies oclusais com lesões ativas de cárie. Durante o primeiro ano de estudo, a freqüência de controle profissional foi $1-4$ para $66 \%$ das crianças e de $5-6$ para $32 \%$. A partir do segundo ano $70 \%$ dos participante foram controlados $1-2$ vezes por ano, ao passo que $30 \%$ de $3-4$ vezes. No final do estudo, após 3 anos, constataram que $10 \%$ das superfícies oclusais necessitaram de selamento e uma de restauração. Em conjunto, os resultados desses estudos apontaram que o selamento como medida preventiva de rotina não promove os benefícios supostamente esperados. $O$ seu emprego indicado individualmente, em associação com outros procedimentos profiláticos, é a estratégia mais racional e eficaz.

DIN195, em 1992, estudou a permanência de selantes autopolimerizáveis em superfícies oclusais de primeiros molares permanentes em crianças com idades entre 6 e 9 anos, durante um período de 6, 12, 18 e 24 meses, encontrando retenções de 92,8 por cento, 87,0 por cento 83,4 por cento e 74,8 por cento, respectivamente após estes meses de avaliação

SUNDFELD et al ${ }^{331}$., 1992, através da análise clínica fotográfica, analisaram a permanência de 2 selantes na superfície oclusal, usando uma solução corante Hematoxilina. Após os 18 meses de análise verificaram que o selante Prisma-Shield (fotopolimerizável) demonstrou uma tendência maior em acentuar perdas do material na margem que o selante Concise (quimicamente polimerizado). 
BOGERT; GARCIA-GODOY28, em 1992, avaliaram "in vitro" os efeitos dos diferentes métodos de profilaxia na resistência ao cisalhamento de um selante de fissura. Sessenta molares permanentes foram divididos em quatro grupos, onde receberam os seguintes tratamentos no esmalte: profilaxia com taça de borracha e pasta com flúor. O esmalte foi condicionado por 30 segundos com ácido fosfórico, lavado, seco e aplicado um selante fotopolimerizável. Os resultados mostraram não haver diferenças estatisticamente significantes entre os quatro grupos, embora o "grupo de água" tivesse obtido a menor resistência ao cisalhamento e o "grupo de pasta sem flúor" a maior média. Embora já tenha sido proposto que tratamentos com flúor antes e depois do condicionamento ácido aumentam a resistência do esmalte diminuindo sua solubilidade, a recomendação de não usar pastas profiláticas com flúor, antes da colocação do selante, não foi suportada pelo presente estudo.

RIPA $^{272}$, em 1993, disse que as primeiras pesquisas clínicas sobre selantes utilizaram materiais a base de cianoacrilatos, os quais foram substituídos posteriormente por materiais a base de dimetacrilatos existentes no mercado. A diferença maior entre as diversas marcas de selantes é o meio de polimerização. Os selantes de $1^{\underline{a}}$ geração eram iniciados pela luz ultravioleta, a $2^{\underline{a}}$ geração de selantes era auto-polimerizável e a $3^{\underline{a}}$ geração usa a luz visível. Os resultados de pesquisas clínicas mostravam maior permanência para selantes de $2^{\underline{a}}$ geração quando comparados com os de $1^{\underline{a}}$ geração. 5 ou 7 anos após a aplicação, dentes com selantes de $1^{\underline{a}}$ geração estavam intatos quando comparados com dentes tratados com selantes de $2^{\mathrm{a}}$ geração. Os selantes de $1^{\underline{a}}$ geração não ficaram muito tempo no mercado. Estudos clínicos indicam que a permanência foi similar para sistemas de $2^{\underline{a}} \mathrm{e}$ $3^{\text {a }}$ geração. A inovação recente é a adição de fluoretos para os selantes. $O$ flúor na saliva a partir do selante é rapidamente liberado, no entanto, de acordo com RIPA ${ }^{275}$ em 1993, são necessários estudos outros para determinar se a adição de flúor melhora a inibição de cárie. Com o propósito de revisar as vantagens do emprego dos selantes de fossas e fissuras, RIPA $^{272}$, em 1993, destacou a permanência como fundamental. RIPA ${ }^{272}$ afirmou ainda que, uma vez que as superfícies de esmalte sejam tratadas com agente condicionador ácido, e que a resina selante tenha sido aplicada, não é provável encontrar-se infiltrações nas margens esmalte-selante. 
Ao analisarem os fatos que influenciam a eficiência dos selantes em prevenir as lesões de cárie, uma vez que em alguns estudos, a eficiência dos mesmos em prevenir as lesões de cárie é questionada, LLODRA et a ${ }^{202}$., em 1993, concluíram que os selantes autopolimerizáveis são os mais efetivos na prevenção da cárie dentária, especialmente se dispõem de sistemas de fluoretação da água de abastecimento. Os selantes fotopolimerizáveis perdem sua efetividade com o passar do tempo de fabricação, sendo necessário reaplicações periódicas. Os autores demonstraram também que a técnica utilizada para aplicação do selante tem bastante influência nos resultados finais.

VIEIRA ${ }^{359}$, em 1993, avaliou a penetração de selantes em fissuras oclusais. O propósito deste estudo foi avaliar sob microscopia de luz, a quantidade de penetração do selante, usando diferentes métodos. Entre os agentes de limpeza, o bicarbonato de sódio e o ultra-som foram os melhores, a água oxigenada e a pedra pomes e água apresentaram desempenho semelhante. $\mathrm{O}$ autor encontrou que a profilaxia é pouco efetiva na penetração do selante.

PARK et $\mathrm{al}^{248}$., em 1993, avaliaram a microinfiltração e resistência ao cisalhamento através de microscopia eletrônica comparando três tipos de selantes: sem carga (Delton), com carga (Prismashield) e com carga liberador de flúor (Fluroshield). Para isto, quarenta e cinco molares humanos hígidos tiveram sua superfície oclusal limpa com pedra-pomes e água. Os dentes foram divididos em três grupos, onde cada um recebeu condicionamento com ácido fosfórico a $50 \%$ por 60 segundos, lavagem, secagem a aplicação dos selantes fotopolimerizáveis correspondentes. Os dentes foram submetidos á ciclagem térmica imersos em fucsina básica a 0,5\% e escores foram dados á penetração do corante. Os resultados não mostraram diferenças significantes de microinfiltração entre os três tipos de selantes. Todos os selantes exibiram formações de prolongamentos poliméricos, os quais promoveram áreas de adesão micromecânicas entre os selantes e a superfície de esmalte condicionada. A microinfiltração foi, portanto, mantida ao mínimo e as forças separadoras causadas por diferentes índices de expansão térmica dos selantes puderam ser substancialmente reduzidas. As 
análises ao microscópio eletrônico (SEM) revelaram que tanto o Prismashield como o Fluroshield adaptaram-se à superfície do esmalte condicionado com um ajuste mais completo que o Delton, apresentando valores significantemente maiores na resistência ao cisalhamento. O Prismashield e Fluroshield exibiram uniforme e contínua formação de prolongamentos como crivos completos em toda superfície oclusal, enquanto o Delton exibiu prolongamentos resinosos difusos.

A pesquisa por materiais dentários com propriedades de liberar fluoreto e assim, por si só, serem capazes de interferir com o desenvolvimento da cárie foi intensa na última década. Entre os trabalhos observa-se o de CURY; $\mathrm{SAAD}^{83}$, em 1993, com o objetivo de estudar o comportamento do selante FluroShield em liberar flúor quando imerso em água deionizada, saliva artificial, ciclagens e pH (soluções desmineralizante e remineralizante). A avaliação de materiais dentários liberadores de flúor tem sido feita em condições que não simulam o meio ambiente bucal, a dinâmica do desenvolvimento da cárie e os conceitos atuais sobre o mecanismo de ação do flúor. Dezoito corpos de prova cilíndricos de $188,5 \mathrm{~mm}^{2}$ de área foram preparados de acordo com as recomendações do fabricante e colocados individualmente em $1,5 \mathrm{ml}$ de meio, totalizando 6 para cada condição experimental. De tempos em tempos e por 15 dias as soluções foram trocadas, sendo determinado íon flúor nas mesmas utilizando-se eletrodo específico. Os resultados mostraram liberação maior em Des-Re do que em água e saliva, diferenças estas estatisticamente significativas ( $P>0,0001)$. Concluiram que a liberação de flúor foi diferente nos meios estudados, sendo observadas concentrações cariostáticas significativas para este selante.

FORSS; SAARNI; SEPPÄ ${ }^{116}$, em 1994, realizaram um estudo clínico a fim de compararem a permanência e o efeito anticariogênico do selante de fissura ionomérico Fuji III e do resinoso fotopolimerizável Delton. Três dentistas aplicaram os selantes em molares permanentes de 166 crianças entre cinco e quatorze anos. Os selantes ionoméricos foram aplicados de um lado enquanto que os selantes resinosos foram aplicados do lado oposto da boca. Após dois anos cada par de molares de 151 crianças foi comparado. 
$26 \%$ dos selantes ionoméricos e $82 \%$ dos resinosos estavam totalmente retidos. Durante os dois anos, $4,6 \%$ das superfícies seladas dos dois grupos cariaram. Os resultados mostraram que a permanência do selante ionomérico foi extremamente menor que a do selante resinoso. Neste estudo, entretanto, nenhuma diferença no aumento de cárie das superfícies seladas foi observada. Isto talvez se deva a diferentes mecanismos na prevenção das cáries dos dois materiais ou a baixa atividade de cáries dos participantes.

SUNDFELD et al ${ }^{332}$., em 1994, analisaram "in vivo" a permanência do selante com flúor Fluroshield, e "in vitro", através de microscopia ótica comum sob luz polarizada, a penetração deste selante no esmalte condicionado. Cento e trinta dentes posteriores, de crianças entre onze e quatorze anos, receberam profilaxia com pedra-pomes e água, seguindo de isolamento absoluto e do condicionamento do esmalte com ácido fosfórico a 37\% sob vibração no interior do sulco, por dois minutos. Após a lavagem e secagem da coroa dental, foi aplicado o selante Fluroshield e polimerizado durante 40 segundos. Para se verificar a penetração do selante no esmalte, um estudo laboratorial foi feito, onde dezesseis dentes posteriores recém-extraídos receberam o selamento oclusal da mesma forma com que foi realizado clinicamente. Os dentes foram então cortados no sentido vestíbulo-lingual, desgastados em fatias de espessura aproximada de $100 \mu \mathrm{m}$ e submetidos à ação do ácido nítrico para posterior remoção do esmalte. As projeções resinosas das porções superior, média, inferior e fundo do selante foram medidas no microscópio ótico comum. Os resultados obtidos na análise clínica após seis meses apresentaram uma taxa de permanência de 96,2\% na superfície oclusal. A análise microscópica dos cortes por desgaste demonstrou uma boa adaptação do selante ao esmalte condicionado em 27 espécimes, sendo que em 5 foi observada falha na interface esmalte/selante. Verificaram uma média de prolongamentos resinosos de aproximadamente $21 \mu \mathrm{m}$ para as regiões superior, média e inferior do selante.

FRANCO; MAGRO; CARVALHO ${ }^{119}$, disseram em 1994, que a aplicação de selantes na região de cicatrículas e fissuras, associada a outras técnicas preventivas, é de grande importância na proteção contra cáries nessas áreas. 
Observaram uma porcentagem de presença total de selantes de 71,30 porcento; este mostrou-se efetivo na prevenção de cáries de cicatrículas e fissuras. Os resultados foram encontrados nos diferentes períodos de permanência de selantes, através de porcentagem média, observada entre 1983 e 1990. Observou-se que, das 345 superfícies oclusais seladas, 246 ou $71,30 \%$ dos dentes com selamento apresentavam presença total na área de cicatrículas e fissuras. Observou-se a ausência em apenas 24 casos (6.94\%), sendo que 7 (2,02\%) apresentavam-se com recidiva de cárie.

Os selantes oclusais devem, para LOVADINO et al ${ }^{204}$., 1994, apresentar as seguintes propriedades: adesão físico-química à estrutura dental, resistência aos fluidos bucais, compatibilidade com os tecidos orais, serem cariostáticos, resistentes à abrasão e às forças resultantes da mastigação. LOVADINO et al ${ }^{204}$., em 1994, avaliando permanência e eficácia na prevenção de cáries com a técnica de selamento de fossas e fissuras oclusais verificaram que após 12 meses, mesmo naqueles dentes em que ocorreu perda parcial de selante, esta não facilitou a instalação de novas lesões cariosas.

Conclusões de LOVADINO et al ${ }^{204}$., após a avaliação clínica em 12 meses comparando selante ionomérico com resinoso:

- Ambos os materiais foram eficientes na manutenção de ausência de cárie da superfície oclusal e interproximal.

- A perda parcial do selante não facilitou a instalação de cárie (em 12 meses).

PALMA et $\mathrm{al}^{247}$., em 1994, colocaram que com o avanço nas pesquisas odontológicas, pode-se associar o selante ao flúor dando assim maior proteção aos dentes, pois há o selamento da superfície oclusal promovido pelo selante, como também a liberação de flúor protegendo, não apenas o dente selado, mas também as estruturas adjacentes. Um dos primeiros selantes com flúor a ser utilizado foi o cimento de ionômero de vidro, ocorrendo, posteriormente, o aperfeiçoamento dos selantes resinosos, tendo adição de flúor à sua composição. A resina fluoretada tem a vantagem sobre o cimento de ionômero de vidro de produzir uma película mais fina e uma superfície mais lisa do selante e, também, uma melhor permanência ao dente, devido ao fato de ser um composto mais fluido que o ionômero, 
permitindo melhor imbricação mecânica, mas com a desvantagem de liberar menos flúor pelo seu fator resinoso. O selante vem evoluindo muito desde a sua criação, e os benefícios na prevenção da cárie dentária parecem melhorar com a adição de flúor à sua composição. O selante fluoretado tem por finalidade atuar não apenas nas cicatrículas e fissuras, mas também a liberação de flúor para os dentes, de forma a propiciar uma conjunção de procedimentos de reconhecida eficiência na prevenção da cárie.

BERNARDES et $\mathrm{al}^{25}$., em 1994, fizeram uma avaliação clínica do selante Fluroshield quanto aos aspectos de permanência e prevenção de cárie, por um período de um ano. Noventa dentes hígidos compreendendo molares e pré-molares de crianças entre seis e doze anos, foram isolados, limpos com pedra-pomes, condicionados com ácido fosfórico a $50 \%$ por 60 segundos e selados com o selante fotopolimerizável Fluroshield por 20 segundos. A aplicação do selante foi restrita apenas aos sulcos e fissuras propriamente ditos. A permanência foi reavaliada aos seis e doze meses após a colocação do selante. Os índices de permanência encontrados aos doze meses foi de $80 \%$ para permanência total, $17,8 \%$ para parcial e $2,2 \%$ para perda total. A maior permanência ocorreu nos pré-molares, seguidos dos molares inferiores e superiores. Alguns fatores responsáveis pelo alto índice de permanência do selante nos pré-molares são a anatomia oclusal, extensão da superfície selada e localização do dente. No mesmo período, a prevenção de cárie foi de $97,8 \%$. O flúor, presente na composição do material, não foi avaliado quanto à influência na retentividade e na prevenção da cárie.

ISHIKIRIAMA; TOMITA; MAGELA ${ }^{169}$, em 1994, relataram que um programa público de selamento de fossas e fissuras apresenta objetivos preventivos, ao contrário dos programas restauradores, que têm por finalidade o tratamento das sequelas da cárie. Relataram também que 0 tempo gasto para a aplicação de um selante é cerca de metade daquele gasto para a confecção de uma restauração de amálgama.

As superfícies oclusais são particularmente suscetíveis à cárie, representando cerca de cinqüenta por cento das lesões cariosas de crianças em idade escolar. Todavia uma drástica redução no número de cáries tem 
sido observada. Grande parte desta ocorrência poder-se-ia creditar a utilização dos selantes de cicatrículas e fissuras (MANTON; MESSER ${ }^{212}$, 1995).

A penetração do selante Fluroshield foi observada "in vivo", por ZUANON et al ${ }^{359}$., em 1995, em esmalte de dentes decíduos previamente condicionados com ácido fosfórico a 37\% por 30 e 120 segundos, utilizando microscopia óptica de luz polarizada. Foram utilizados 28 molares decíduos em época de esfoliação, que receberam a aplicação do selante na presença de isolamento relativo e após 7 dias foram extraídos. As coroas dentais foram seccionadas e lixadas, obtendo-se fragmentos de espessura inferior a $100 \mu \mathrm{m}$, os quais foram montados em lâmina de vidro e descalcificados com ácido nítrico a $40 \%$, até se obterem apenas o selante e suas projeções resinosas. Estes foram imersos em água destilada, cobertos com uma lamínula de vidro e levados ao microscópio. Os valores médios para o comprimentos dos tags foram de 18,75 e 31,97 um para 30 e 120 segundos, respectivamente. Após a obtenção desses valores e da análise estatística, pôde-se concluir que 0 condicionamento ácido de molares decíduos durante 120 segundos proporcionou maior penetração do selante Fluroshield, quando comparado com 30 segundos. Considerando a região da fossa oclusal (superior, média ou inferior), não houve diferença quanto à penetração do material para ambos os tempos de ataque ácido.

EARLE; KAZIMIROFF; JEFFERIES ${ }^{101}$, em 1995, avaliaram clinicamente a performance de restauração oclusal com resina Fluorocore associada a aplicação de selante Fluroshield em 36 cavidades classe I em pacientes cárie-ativos. As avaliações foram realizadas após 3,6,8,12 e 18 meses após a confecção da restauração e os resultados demonstraram que as superfícies apresentavam características positivas incluindo ausência de sensibilidade pós-operatória, ausência de cáries recorrentes, ausência de descoloração marginal, boa integridade marginal e textura de superfície, 100 por cento de permanência e nenhuma falha de material foi observada. O uso de selante como um selante de superfície para o compósito foi benéfico e deve ser recomendado como um selante de superfície para restaurações posteriores de resina composta. 
SUNDFELD et al. ${ }^{333}$, em 1996, tal como JENSEN et al. ${ }^{176}$, em 1990, puderam verificar uma excelente taxa de permanência do selante Fluroshield na superfície dental 12 e 18 meses após sua aplicação, respectivamente, ressaltando ainda que a adição e subseqüente liberação de flúor pareceu não afetar a permanência do material ao longo do tempo.

CAMLOFFSKI; MAZUREK ${ }^{57}$, em 1996, disseram ser função dos selantes isolar fisicamente a superfície do esmalte dentário do meio ambiente bucal, impedindo os efeitos deletérios dos elementos ácidos produzidos pelas bactérias da placa. Diante disto, adquire singular importância a qualidade da permanência dos selantes. Com estudo que avaliou clinicamente a permanência do selante FluroShield e do selante Delton em primeiros molares permanentes, onde foram selados 120 molares de 30 crianças e foram feitas avaliações aos 6,12 e 18 meses após a aplicação, CAMLOFFSKI; MAZUREK ${ }^{57}, 1996$ constataram perda total do selante somente 6 meses após a sua aplicação, de 1,73\% para o FluroShield e 5,17\% para o Delton. O selante FluroShield mostrou-se mais eficaz que o selante Delton aos 6 meses, com permanência parcial de 6,89\% e permanência completa de $91,38 \%$, e também aos 12 meses, com permanência parcial de $4 \%$ de permanência completa de $96 \%$. O selante Delton apresentou permanência parcial de $15,52 \%$ e permanência completa de $79,31 \%$ aos 6 meses, e aos 12 meses, permanência parcial de 13,64\% e permanência completa de $86,36 \%$. Aos 18 meses, a permanência parcial do selante FluroShiels foi de $10,86 \%$ e a permanência completa foi de $89,14 \%$, índices semelhantes aos do selante Delton, que apresentou permanência parcial de $10,86 \%$ e permanência completa de $89,19 \%$.

CHIBINSKI; CZLUSNIAK ${ }^{73}$, 1996, afirmaram que a longevidade de um selante, no que diz respeito à permanência, depende única e exclusivamente de adesivo e aderente. $O$ adesivo (selante) precisa apresentar condições físico-químicas adequadas e o aderente (esmalte dental) deve ser tratado de modo a fornecer condições básicas de adesão ao selante (topografia de superfície, carência iônica, baixa energia de superfície).

CZLUSNIAK; RODRIGUES; VASSAO ${ }^{84}$, em 1995, avaliando a penetração de selantes em fóssulas e fissuras, obtiveram melhores índices de penetração 
com selantes sem carga. Embora tenham sido desenvolvidos com objetivos distintos, tanto a pesquisa de CZLUSNIAK; RODRIGUES; VASSAO ${ }^{84}$, quanto o trabalho de CHIBINSKI; CZLUSNIAK ${ }^{73}$, em 1996, mostraram que os selantes sem carga reúnem propriedades ideais necessárias a um adesivo e, demonstraram a impossibilidade de se discutir permanência sem falar em penetração dos selantes.

É importante considerar aqui o selante aplicado em um elemento dentário ativo do sistema estomatognático, passível de desgaste e abrasão frente ao stress mastigatório. Sua efetividade não dependerá da fina película que veda a superfície da fissuras, que pode ser facilmente desgastada, e sim do material selador que oblitera um sulco, através de sua penetração em toda extensão da cicatrícula e de sua permanência aumentada em virtude da maior formação de tags (imbricação mecânica superior). Por outro lado, devese esperar uma maior resistência ao desgaste por parte dos selantes com carga. É inerente a este tipo de material a formação de uma película mais espessa, o que obriga o ajuste oclusal após sua aplicação, já que o desgaste não se processará naturalmente e o desconforto será evidente para o paciente (STACH et al..$^{317}$ 1992).

SILVA; ARAÚJO; REGO ${ }^{299}$, em 1996, avaliaram clínicamente o efeito de materiais e tempos de análise, em dois selantes de fossas e fissuras, sendo um auto e outro fotopolimerizável. Foram realizados 164 selamentos em 162 dentes (pré-molares e molares) que não apresentavam evidências clínicas e radiográficas de cárie, em 27 pacientes, sendo 81 aplicações do Deltonautopolimerizável e 83 do Delton-fotopolimerizável. O selamento foi realizado com isolamento absoluto do campo operatório, condicionamento ácido com ácido fosfórico a $37 \%$ por 60 segundos, profilaxia prévia ao condicionamento com escova robson em baixa rotação e pedra pomes e em seguida lavagem da superfície a ser condicionada com água oxigenada a $3 \%$. A fotopolimerização foi com luz visível aplicada durante 40 segundos, sendo que os autores esperaram 20 segundos para escoamento do selante aplicado antes de iniciar a fotopolimerização. A presença do selante em todas as fossas e fissuras, adaptação marginal, presença de cárie e irregularidades superficiais eram verificada após 6, 12, 18 e 24 meses das aplicações, classificando-se os selantes em satisfatórios, aceitáveis e insatisfatórios. Não 
foram observadas diferenças estatisticamente significantes no comportamento clínico entre os selantes auto e fotopolimerizável, assim como entre as aplicações nas arcadas superior e inferior. Após 12 meses de controle encontraram um total de $99,39 \%$ de efetividade.

SILVA; REGO; ARAÚJO ${ }^{300}$, em 1996, dizendo que aproximadamente metade das cáries em crianças e a maioria aos 15 anos de idade, são cáries oclusais sendo este número reduzido com a aplicação de selantes, avaliaram clinicamente a eficiência e durabilidade de selamento com um selante com carga e flúor (Fluroshield), e com cimento ionômero de vidro (Variglas) em dentes submetidos à ameloplastia. Foram aplicados selantes em 92 dentes (pré-molares e molares de 31 pacientes) os quais foram avaliados após 6 e 12 meses. Não ocorreu presença de cárie oclusal em todas as avaliações. Não ocorreram diferenças significativas no comportamento clínico entre o Fluroshield e o Variglas. Ambos selantes apresentaram permanência satisfatória após 12 meses da aplicação, com 96,72 por cento de permanência total para o Fluroshield e 93,55 por cento para o Variglas.

REGO; ARAÚJO262, em 1996, realizaram uma avaliação clínica de selantes de fossas e fissuras, com e sem flúor, pelo período de dois anos. Aproximadamente metade das cáries em crianças e a maioria aos 15 anos de idade são cáries oclusais, sendo este número reduzido com a aplicação de selantes. O objetivo do trabalho foi avaliar clinicamente eficiência e durabilidade de um selante com carga e flúor em dentes submetidos à ameloplastia e de selante sem carga e flúor aplicado sem uso da técnica invasiva. Foram aplicados 192 selantes fotoativados (109 FluroShield e 105 Delton) em 153 dentes pré-molares e molares de 32 pacientes, com faixa etária entre 9 e 16 anos, os quais foram avaliados após 6, 12, 18 e 24 meses. A aplicação de selantes foi realizada com isolamento absoluto, profilaxia da superfície de esmalte a ser selada com água oxigenada a $3 \%$ e condicionamento ácido do esmalte com ácido fosfórico a 37\% aplicado por 60 segundos. Após aplicado o selante aguardou-se 20 segundos para iniciar a fotopolimerização que foi realizada com luz halógena aplicada por 40 segundos. Realizada uma inspeção inicial e estando o selante satisfatório foi aplicado flúor gel ( Nupro“, Johnson \& Johnson) por 5 minutos antes da 
remoção do isolamento absoluto. Nos controles realizados após seis, doze meses e dezoito meses a permanência de selantes verificada foi de 100 por cento, enquanto aos 24 meses foi de 93,75 por cento, não ocorrendo a presença de cárie oclusal em todas as avaliações. Não ocorreram diferenças significativas no comportamento clínico entre o FluroShield e o Delton, nem também entre os selantes nas arcadas superior e inferior.

VONO; VONO; FIGUEIREDO ${ }^{361}$, realizaram estudo em 1996, com a técnica invasiva de selamento de fossas e fissuras, para a comparação entre selante com carga e com flúor e ionômero de vidro. Fossas e fissuras de 296 molares permanentes foram seladas, pela técnica invasiva, com selante com carga e com flúor (Fluroshied) e com ionômero de vidro (Variglass VLC). Aos 6, 12, 18 e 24 meses após o tratamento, as condições dos materiais foram avaliadas clinicamente, quanto aos seguintes aspectos: material sem alteração, material com perda de volume oclusal, exposição das margens cavitárias, fratura do material e ausência total do material. O selante teve um desempenho clínico superior ao do ionômero, com diferenças estatisticamente significantes. Quanto à prevenção de cáries proximais nos molares tratados, observadas radiograficamente, ambos os materiais foram eficazes e tiveram efeito semelhante. Em 1997 SERRA; PIMENTA; PAULLILO ${ }^{296}$, colocaram que mudanças conceituais acontecem na filosofia atual de decisão e indicação de tratamentos. Eles disseram que durante muito tempo, a Dentística se preocupou apenas com os preparos e as restaurações de cavidades. Essas condutas adotadas convencionalmente pela "Dentística Tradicional" cuidam apenas de seqüelas, acreditando que técnicas operatórias seriam capazes de tratar a doença cárie. Entretanto, esta filosofia de "tratamento" leva, muitas vezes, a mutilação progressiva das estruturas dentais. Por isso, o profissional consciente não deve se restringir a atos meramente curativos, através de restaurações, ou mesmo da remineralização de lesões. Em virtude do maior conhecimento da etiologia das doenças e do reconhecimento da odontologia como área de saúde, houve uma mudança considerável nos conceitos de tratamento. A "Dentística Tradicional", que buscava apenas estabelecer forma, função e às vezes, estética, vem sendo substituída por uma Dentística cada vez menos restauradora, que tem como objetivos principais: prevenir novas lesões, paralisar as já existentes e evitar as recorrentes. As 
mudanças conceituais, associadas ao desenvolvimento tecnológico e científico, influenciaram diretamente os procedimentos clínicos que visam à promoção da saúde bucal. Esses procedimentos incluem, além de preparos biomecânicos e restaurações fundamentadas no princípio de conservação de estrutura dental, o tratamento das causas da doença cárie. Em pacientes de alto risco ou atividade de cárie, pode-se também selar cicatrículas e fissuras, com o objetivo de ocupar uma área preferencial de formação de placa. A decisão sobre a necessidade de condutas preventivas ou invasivas está fundamentada no diagnóstico. Em casos de inatividade da lesão não se indica restauração, visto que uma cárie paralisada torna-se mais resistente a novos desafios cariogênicos. Em fossas, cicatrículas e fissuras, se a dificuldade de controle de placa levar a um maior risco de progressão das lesões, recomenda-se o uso terapêutico de selante como uma alternativa não invasiva para o tratamento de lesões de cáries questionáveis ou incipientes. O selamento oclusal em lesões paralisadas de fossas, cicatrículas e fissuras, embora sem necessidade terapêutica, seria indicado apenas com objetivo estético ou "antiatrogênico", para prevenir futuras intervenções invasivas, por profissionais que ainda não compartilham da filosofia de promoção de saúde e acreditam que uma cárie paralisada se torna facilmente ativa. Considerando que nenhum material restaurador substitui com excelência a estrutura dental sadia, colocaram ainda os autores, selamento invasivo é totalmente contraindicado, até porque o procedimento operatório dessa técnica torná-la-ia uma restauração, e não um selamento.

CAVALCANTI et al. ${ }^{69}$, em 1997, dissertando sobre os fundamentos dos selantes de fossas e fissuras dentais citaram a importância destes como material a ser utilizado rotineiramente na clínica odontológica, com a finalidade específica de prevenção de cárie. Apresentaram as propriedades dos selantes e a necessidade de selar ou não os dentes posteriores, tendo em vista suas características anatômicas peculiares e os benefícios esperados da utilização do material, em situações clínicas que devem ser criteriosamente selecionadas.

CARLSSON; PETERSSON; TWETMAN ${ }^{61}$, nesse mesmo ano, realizaram estudo com objetivo de avaliar o comportamento clínico de Helioseal F um 
selante com flúor, em crianças escolares com alto risco cárie. Foram triadas 204 crianças de 6 e 7 anos de idade com alto índice de cárie (baseado em experiência de cáries anteriores, teste de saliva, capacidade tampão e freqüência de ingestão de açúcar). Crianças que apresentavam 2 ou mais fatores de risco era considerados susceptíveis a cárie (alto risco), num total de 121 crianças, e os molares permanentes destas crianças eram selados com selantes fluoretados, este grupo era chamado grupo com selante (FSG). As outras 83 crianças com baixo risco à cárie não receberam o selante e eram incluídas no grupo controle ambos os grupos eram acompanhados por 2 anos. De 15 crianças de ambos os grupos era coletada saliva 1 mês após a colocação do selante, com finalidade de avaliar o nível de flúor. Em outras 20 crianças era realizado um estudo para comparar a colonização de streptococcus mutans adjacente aos selantes com flúor. Os selantes eram aplicados por técnicos em higiene dental seguindo as recomendações do fabricante. Resultados: de um total de 431 selantes $76,6 \%$ dos dentes não perderam o selante, $22,0 \%$ perderam parcialmente e 6 selantes $(1,4 \%)$ foram completamente perdidos. A incidência de cárie no esmalte era $45 \%$ mais baixa $(p<0,005)$ nos dentes molares com alto risco de cárie comparado com os de baixo risco. Não houve aumento significante na concentração de flúor na saliva após a colocação do selante e a proporção de streptococcus mutans em relação ao conteúdo inicial não era afetada pelo tipo de material. O nível de estreptococcus era mantido durante o tempo de estudo, mas o nível de lactobacilos na saliva diminuía.

GALARNEAU; BRODEUR ${ }^{122}$, em 1998, realizam trabalho com propósito de estimar o conhecimento dos pais de crianças de 11 a 12 anos sobre selamento dental e os principais fatores associados. A prevalência de selantes em crianças de 11 a 12 anos de idade em Quebec, Canadá, era de 29\% no levantamento de Saúde Pública realizado em 1996-1997. Poucos artigos sobre relação de conhecimento sobre dos pais selamento são encontrados na literatura. Esse estudo transversal foi realizado com 7255 pais de crianças da 6a série escolar que responderam a um questionário entre novembro de 1996 e abril de 1997. As crianças haviam sido cobertas por um programa de seguro saúde do nascimento até os 10 anos de idade que incluía exames, prevenção e restauração, mas não envolvia selamento. $57 \%$ da amostra 
haviam ouvido falar sobre selamento, sendo o consultório odontológico a principal fonte de informação. Entretanto, 39\% dos pais de crianças que haviam ido ao dentista no último ano, nunca tinham ouvido falar sobre selamento. Os principais fatores associados ao conhecimento sobre selante foram visitas regulares ao dentista e conversas. O conhecimento sobre selamento foi duas vezes mais freqüente em pessoas que tinham ido ao dentista nos últimos anos do que naquelas que não o fizeram, e duas vezes superior nas pessoas de língua inglesa do que nas de língua francesa. $O$ conhecimento sobre selamento é muito pequeno, levando em consideração que $84 \%$ das crianças haviam ido ao dentista no último ano. Para esses autores, consequentemente, campanhas promocionais nesse sentido deveriam ser empreendidas pelos profissionais.

Dois materiais utilizados como selante oclusal (Fluroshield e Vitremer) tiveram seu desempenho avaliado, por VILLELA et al. ${ }^{360}$, em 1998. Foram selados 46 pré-molares, superiores e/ou inferiores, sem sinais clínicos de lesões de cárie, sendo que 23 dentes foram selados com Vitremer e $23 \mathrm{com}$ Fluroshield. Após 6, 12 e 24 meses de acompanhamento, observou-se que o Vitremer apresentou uma permanência total de 91,30 por cento, 91,30 por cento e 82,60 por cento nestes períodos, enquanto o Fluroshield apresentou 100 por cento de permanência total nos três intervalos de tempo. Ambos os materiais impediram o desenvolvimento de lesão de cárie, independente de sua permanência e períodos avaliados. Concluíram que: após seis e doze meses de acompanhamento clínico, não foi observada diferença estatisticamente significante no grau de permanência dos dois selantes avaliados; após vinte e quatro meses de acompanhamento clínico, o selante Fluroshield apresentou permanência estatisticamente superior ao selante Vitremer, tanto nos dentes selados com Fluroshield quanto nos selados com Vitremer não foi observada incidência de lesões de cárie após vinte e quatro meses de acompanhamento clínico.

Em 1999, FELIPE et al. ${ }^{109}$, estudaram a aplicação do selante em margens degradas de restaurações em pacientes livres de cárie e afirmam que esta é uma indicação adequada. Eles afirmaram que o diagnóstico da doença cárie, hoje, considera os dados da anamnese, como hábitos dietéticos e a higiene do paciente, em conjunto com o exame clínico e radiográfico interproximal 
complementar. Assim, muitas restaurações que apresentam margens degradadas em pacientes livres de cárie podem ser mantidas e observadas ao longo do tempo, ao invés de trocadas. O estudo avaliou o selamento das margens de restaurações de amálgama em 25 dentes "in vitro" e 5 dentes em "in vivo". Os dentes, antes do selamento, apresentavam restaurações de amálgama classes I e II com as margens valadas. Os resultados "in vitro" mostraram que a presença do selante reduz a baixos níveis a infiltração no local aberto da margem, acumulando a deposição alimentar e a predisposição do local para a doença. Todos os dentes selados "in vivo" mantiveram-se satisfatórios pelo período de 2 anos, com permanência do selamento. Através dos resultados obtidos concluiram: a técnica de selamento marginal de restaurações de amálgama não conseguiu eliminar totalmente, in vitro a infiltração na interface selante-amálgama. Embora a infiltração não tenha sido totalmente eliminada pelo selante, houve uma redução significativa na quantidade e consequentemente, na predisposição ao desenvolvimento de cárie nesse local. Clinicamente houve permanência do selamento no período avaliado de dois anos. A troca da restauração pode ser adiada, se não evitada, com a utilização de um selante nos locais degradados das margens de uma restauração de amálgama, quando os aspectos analisados do paciente são favoráveis.

CENTENARO et al. ${ }^{70}$, em 1999, realizaram estudo com objetivo de comparar a eficácia e permanência do selante oclusal realizado com um selante resinoso (Fluroshield-Dentsply) e um cimento de ionômero de vidro (Fuji IX- GC). Cinqüenta crianças com idade de 7 a 9 anos cujos 4 primeiros molares permanentes estavam hígidos e completamente irrompidos, totalizando 200 dentes foram selecionadas para este estudo após o consentimento dos pais. Os dentes foram divididos em dois grupos de acordo com o material: Grupo 1 (dentes 16 e 36) selados com Fluroshield, Grupo 2 (dentes 26 e 46) selados com Fuji IX. A limpeza prévia dos dentes foi feita com escovas dentais infantis e água. Os dentes foram isolados com roletes de algodão e os materiais foram aplicados segundo instruções do fabricante. Realizaram exame clínico dos dentes após seis meses com o auxílio de sonda exploradora e refletor de luz. Os resultados após seis meses mostraram respectivamente para Fluroshield e Fuji IX: 14\% e 12\% de perda 
parcial; 1 e $0 \%$ de perda total e $70 \%$ de permanência total do material. Não houve diferença estatisticamente significativa entre a permanência dos produtos estudados. Embora os níveis de permanência tenham sido considerados baixos, não houve incremento no índice de CPOD para ambos os grupos estudados.

SALLES et al. ${ }^{292}$, em 1999, realizaram trabalho em que o objetivo foi avaliar clinicamente a permanência e efetividade de selantes de fossas e fissuras de pacientes da Clínica Integrada Infantil do Curso de Odontologia da Universidade estadual de Maringá. Foram avaliados 202 molares (123 permanentes e 79 decíduos) de 45 crianças que receberam o selamento entre os anos de 1995 e 1998. Os períodos de controle variaram de 6 a 36 meses. Empregou-se a inspeção visual da área corada, estando a superfície seca e bem iluminada, com auxílio de espelho bucal e da sonda exploradora no. 5, realizada por 2 examinadores calibrados. Os critérios para a avaliação do selante foram: totalmente selados, perda parcial, ou total, molares não selados, restaurados ou ausentes. Os dentes com perda parcial ou total do selante foram avaliados quanto a presença ou não de cáries. Observou-se que $16 \%$ dos selantes soltaram-se no período compreendido de 6 a 12 meses, subindo para 53\% no período de 13 a 24 meses: $8,4 \%$ dos molares avaliados apresentam-se cariados e ou restaurados devido a perda e/ou total do selante. No período de 6 a 12 meses, um dente apresentou-se cariado após a perda parcial ou total do selante. No segundo ano de controle este número subiu para 5 e no terceiro foram 9 os dentes cariados.

Definindo selantes BUSSADORI; IMPARATO; GUEDES PINTO ${ }^{56}$, em 2000, disseram: selantes de fossas e fissuras são materiais empregados como coadjuvantes no tratamento da doença cárie em dentes posteriores, promovem o vedamento das fossas, cicatrículas e fissuras obliterando o habitat preferível dos streptococcus mutans e facilitando a auto limpeza. 


\subsection{ASSOCIAÇÃO DO FLÚOR TÓPICO, À TÉCNICA DE SELAMENTO, COMO MÉTODO DE PREVENÇÃO DE CÁRIE.}

BRUDEVOLD et al. ${ }^{48}$, em 1963, afirmaram que a absorção de flúor pelo esmalte é maior a partir de soluções fluoretadas aciduladas com ácido fosfórico, do que com soluções neutras.

CAPOZZI et al. ${ }^{58}$, em 1967 estudando a ação de alguns compostos fluoretados sobre o mecanismo enzimático de bactérias cariogênicas concluiram que NaF está entre as substâncias com maior capacidade de inibição destes microrganismos.

Em 1973 GWINNETT ${ }^{143}$ alertava para o fato de que a aplicação de flúor não deveria ser feita antes da aplicação de um selante, pois a superfície do esmalte reagiria com o flúor, produzindo produtos de reação que diminuiriam significantemente as resistências das ligações selante-esmalte.

Segundo GOURLEY'138 (1975); ROCCA et al. ${ }^{277}$ (1979); BASSO ${ }^{23}$ (1983), entre outros, a ação do flúor é dotada de limitações no processo preventivo da lesão de cárie, conferindo maiores benefícios às superfícies lisas que às oclusais, principalmente, devido à complexidade anatômica dos sulcos e fissuras dessa face, fato que já havia sido verificado por FORREST ${ }^{114}$, em 1956.

GRAVES; BURT ${ }^{140}$, em 1975, mostraram que em uma comunidade com água fluoretada $90 \%$ das lesões cariosas em primeiros molares permanentes de escolares eram lesões de fossas e fissuras.

Os estudos sobre selantes tem o objetivo de verificar a capacidade de prevenir cáries e o grau de permanência ao longo do tempo. A comparação do efeito de controlar cárie, com a utilização de selante de resina e de ionômero de vidro, foi estudada por WILLIAMS; PRICE; WINTER ${ }^{375}$, em 1978, não verificando diferença significante. 
No ano de 1979 RANTALA ${ }^{260}$, em trabalho com escolares na faixa etária de 7 a 9 anos, estudou a eficácia da utilização combinada de selantes com aplicações tópicas de fluoreto acidulado. Após 2 anos de acompanhamento, informou que este uso combinado determinou um aumento de primeiros molares permanentes livres de cáries de $50,0 \%$ para $81,0 \%$.

Para MENAKER ${ }^{224}$, em 1984, os selantes de fossas, cicatrículas e fissuras devem ser considerados como um método auxiliar, e não substituto, da aplicação de fluoretos tópicos. Estes oferecem maior proteção às superfícies lisas dos dentes, nas faces vestibular e lingual, assim como interproximal. Os selantes, por outro lado, foram projetados para selar e proteger defeitos do esmalte, locais que podem aprisionar resíduos orgânicos e manter a atividade cariogênica. Nestas áreas os fluoretos oferecem menor proteção.

O fluoreto tópico e o selante são, portanto, complementares. A aplicação do selante e tratamento por fluoreto podem ser combinados em uma única sessão, fazendo parte de um único programa preventivo. Algum cuidado deve ser observado na seqüência de tratamento por selante e fluoreto, quando combinados em uma única sessão.

Se o tratamento tópico de fluoreto for feito antes da aplicação do selante, o fluoreto será removido de toda área atacada pelo ácido empregado antes do selante. Por outro lado, alguns pesquisadores tem sugerido que o tratamento por fluoreto poderá ser benéfico antes da aplicação do selante, uma vez que pequena quantidade de fluoreto poderá ficar retida nas fissuras. Conquanto esta permanência de fluoreto possa ser possível, se o fluoreto alcançou essa área também o líquido de ataque o fará. Dessa maneira, parece questionável se alguma quantidade apreciável de fluoreto permaneceria na fissura. Com a aplicação prévia de fluoreto, também os íons seriam removidos de superfícies lisas atingidas pelo ataque ácido. Dessa forma, uma valiosa proteção pelo fluoreto seria perdida de áreas proximais e gengivais, se o líquido de ataque não for judiciosamente mantido na superfície oclusal.

A seqüência preferida para tratamento associado de selante e fluoreto em uma única sessão será, portanto, aplicar de início o selante e depois o fluoreto. Esta seqüência assegura que toda área não protegida pelo selante venha a sê-lo pelo fluoreto. Desde que os materiais empregados para 
aplicação tópica de flúor não parecem ter efeito danoso sobre os selantes, os métodos de rotina de aplicação de fluoreto podem ser seguidos. Como ganho extra, toda área atacada pelo ácido e eventualmente não protegida pelo selante incorporará uma quantidade maior de flúor.

DUARTE ${ }^{99}$, em 1985, apresentou resultados de um trabalho desenvolvido com um grupo de 40 crianças na faixa etária de 5 anos e meio a 6 anos e meio, onde foram aplicados selantes em 90 primeiros molares permanentes sendo que em 45 foi também aplicado o fluoreto de sódio acidulado. Após 4 e 8 meses de acompanhamento, certificou-se que a permanência do selante é melhor nos inferiores que nos superiores e que, na porção distal a perda do selante ocorre com maior freqüência. A associação selante e aplicação tópica de solução fluoretada além de aumentar o grau de permanência do selante, determina uma diminuição de cáries nas superfícies lisas, indicando uma boa combinação num programa de prevenção de cáries dentárias.

MCKENNA; GRUNDY'218, em 1987, citaram que o selante fluoretado promove uma liberação de flúor semelhante a uma aplicação tópica de flúor por um longo período de tempo, mas, através dos resultados, notaram que há uma boa liberação nas primeiras horas, vindo a diminuir significativamente na primeira semana, e estabilizando-se a seguir.

Com o objetivo de tentar elucidar dúvidas a respeito da influência da aplicações tópicas de flúor na permanência dos selantes oclusais, TAVARES et al. ${ }^{341}$, em 1987, propuseram a seguinte pesquisa: testar o grau de permanência do selante oclusal em primeiros molares permanentes, após decorridos 5 e 10 meses das aplicações, nas seguintes condições:

A - quando a aplicação do selante é realizada associada a uma exposição ao flúor tópico;

B - quando a aplicação do selante é realizada a uma exposição posterior ao flúor tópico;

C - quando a aplicação do selante é realizada sem associação de flúor tópico. 
Foram selados, ao todo, 144 primeiros molares permanentes selecionados em 42 crianças que possuíam os molares hígidos.

A amostra foi dividida em 3 grupos.

Grupo I- Recebeu uma aplicação tópica de flúor fosfato ácido após a profilaxia e antes do ataque ácido e do selante.

Grupo II- Recebeu uma aplicação tópica de flúor fosfato ácido após a aplicação do selante.

Grupo III- Não recebeu a aplicação tópica de flúor (grupo controle).

O selante utilizado no trabalho foi o Delton (Johnson \& Johnson do Brasil).

A aplicação dos selantes foram realizadas por um único pesquisador, com um auxiliar, empregando-se a técnica de aplicação preconizada por ISSAO; ANDO ${ }^{172}$, em 1983, e utilizando-se a mesma técnica para os 3 grupos em estudo. O flúor fosfato ácido utilizado foi o Flúor-Gel (Odacham).

O isolamento relativo com rolos de algodão e auxílio do sugador de saliva foi o escolhido pelos autores porque, segundo trabalhos de EIDELMAN; FUCKS; $\mathrm{CHOSACK}^{103}$, de 1983, não existem diferenças significativas quando comparados os resultados obtidos com isolamento absoluto.

A avaliação da permanência do selante foi feita através de exame clínico utilizando-se sonda exploradora $\mathrm{n}^{\circ} 5$ e espelho bucal. Foram realizadas 2 avaliações aos 5 e 10 meses por um dos autores no próprio colégio.

Resultados mostraram que, de um total de 122 dentes, 44 dentes (grupol) receberam selantes com aplicação anterior de flúor tópico, 41 dentes (grupo II) receberam selantes com aplicação posterior de flúor tópico e 37 dentes (grupolli) receberam selantes sem aplicação de flúor.

No grupo I, em avaliação realizada 5 meses após a aplicação do selante, a percentagem de permanência total do selante foi de $93,2 \%$ e após 10 meses foi de 79,5\%. Houve perda parcial após 5 meses 18,2\%, após 10 meses decorrido meses a perda total foi de $2,3 \%$, dado corresponde a 1 dente que, momento da avaliação, encontrava $89,2 \%$ restaurado com amálgama (classe $\mathrm{MO})$, não sendo possível elucidar-se, houve perda do selante ou apenas uma cárie proximal. Neste grupo ocorreu a maior perda do selante entre 2 avaliações.

No grupo II, em avaliação realizada após 5 meses, a percentagem permanência total do selante foi $95,1 \%$ e após 10 meses foi de $85,3 \%$. Houve 
perda parcial de 4,9\% após 5 meses e de 14,7\% após de 10 meses. Neste grupo não houve perda total.

Comparando os dados dos grupos I e II na avaliação realizada após 5 meses, observou-se que a permanência total foi de 93,2\% e 95,1\% respectivamente, diferença esta que não foi estatisticamente significante a nível de $5 \%$, o que parece indicar que não há influência do momento da aplicação tópica de flúor. Na avaliação realizada aos 10 meses, a diferença entre os grupos I e II foi maior $(79,5 \%$ e $85,4 \%$, respectivamente) e, embora a diferença não seja estatisticamente significante a nível de 5\%, nota-se uma tendência para melhor permanência do selante no grupo onde o flúor é aplicado posteriormente ao selante.

No grupo III, a percentagem de permanência total do selante foi de $89,2 \%$ após 5 meses e de $86,5 \%$ após 10 meses. Houve perda parcial de $10,8 \%$ após 5 meses e 10 meses de observação. Após 5 meses a perda total do selante foi nula e após 10 meses foi de $2,7 \%$. O resultado da avaliação após 5 meses, no grupo III, foi inferior aos demais, pois atingiu apenas 89,2\% dos dentes selados. A maior perda parcial entre as 2 avaliações realizadas foi no Grupo I, onde aos 5 meses tiveram $6,8 \%$ e aos 10 meses 18,2\%. Nos Grupos II e III os resultados para 5 e 10 meses são, respectivamente, 4,9\% e $14,6 \%$ no Grupo II e 10,8\% para ambos os períodos no Grupo III.

Estes dados reforçam a afirmação de NIH CONSENSUS DEVELOPMENT CONFERENCE ${ }^{241}$ que, em 1984, recomendou o uso de flúor tópico após a aplicação do selante.

De acordo com trabalho de TAVARES et al. ${ }^{341}$ :

No Grupo I, os resultados obtidos aos 5 e 10 meses de avaliação para a permanência do selante oclusal foram, respectivamente, 93,2\% e 79,5\%.

No Grupo II, aos 5 e 10 meses, os resultados obtidos para a permanência do selante oclusal foram, respectivamente 95,1\% e 85,4\%.

No Grupo III, aos 5 e 10 meses, os resultados obtidos para a permanência do selante oclusal foram, respectivamente $89,2 \%$ e $86,5 \%$.

Pela análise estatística a que foram submetidos os resultados, concluíram que o grau de permanência do selante oclusal, após 5 e 10 meses de aplicação, não difere estatisticamente nas 3 condições testadas. Entretanto, houve um tendência para melhor grau de permanência do selante oclusal quando a aplicação do selante é associada a uma exposição 
posterior ou quando não há exposição ao flúor tópico (Grupos II e III), do que uma exposição prévia ao flúor tópico (Grupo I). Desta forma, quando a aplicação do selante oclusal for acompanhada de uma aplicação tópica de flúor, TAVARES et al. $^{341}$, em 1987 recomendaram que esta seja feita posteriormente ao selante oclusal.

A "redução da infecção" é efetiva através do flúor que, como uma das medidas para o controle da doença cárie, tem por objetivo inibir o fenômeno de desmineralização e ativar a remineralização. A fluorterapia deve ser feita dentro de uma forma racional, segundo a qual o uso de fluoretos vai diminuindo de acordo com a real necessidade, objetivando-se, assim, paralisar as lesões já estabelecidas e conseguir, em função do tempo, manter o controle da doença cárie pelo simples uso de um método de alta freqüência a baixa concentração de fluoreto (CURY'11, 1989).

JENSEN et al. ${ }^{174}$, em 1990, colocaram que o flúor reduz solubilização do esmalte e estimula remineralização de lesões cáries recentes. Aplicação tópica profissional periódica com altas concentrações de flúor é ligeiramente menos efetiva que exposições diárias à baixas concentrações Por este motivo tem sido incorporado o flúor em número grande de materiais odontológicos, incluindo amálgama, vernizes cavitários, cimentos ou resinas compostas. 0 selante agiria como um reservatório do qual o flúor acrescentado seria gradualmente liberado na cavidade oral, o que inibiria a desmineralização do esmalte e estimularia a remineralização.

Muitos estudos têm sido feitos para se incorporar o flúor em selante de cicatrículas e fissuras. Foram feitas duas tentativas: a) flúor acrescentado à resina não polimerizada, sob a forma de um sal solúvel e neste caso o flúor será liberado do selante polimerizado através da dissolução do sal. Tem sido questionado se esta liberação de flúor poderia enfraquecer o selante in situ, o que diminuiria sua efetividade como agente de prevenção. b) flúor acrescentado à resina sob forma de sal orgânico fluoretado unido ao polímero insolúvel e neste caso o flúor seria liberado por troca iônica. Este último tipo de selante fluoretado tem liberado flúor gradativamente e por tempo maior. 
Um estudo clínico de JENSEN; BILINGS; FEATHERSTONEE ${ }^{175}$, em 1990, foi realizado com objetivo de: determinar a permanência do Fluroshield, um selante contendo sal fluoretado solúvel, durante um período de 1 ano, comparando com um selante análogo sem flúor Primashield e avaliar a biocompatibilidade e distribuição oral do flúor liberado. $O$ estudo foi realizado para avaliar a quantidade proporção e distribuição oral do flúor liberado por Fluroshield, um selante a base de Bis-GMA, contendo fluoreto de sódio a $2 \%$ e um agente promotor de adesão a $1 \%$. Além disto comparar a permanência in vivo deste selante, quando comparado com o selante análogo Prismashield. Foram selados 147 pares de molares hígidos em 82 crianças. Amostras da saliva foram coletadas de 20 pacientes selecionadas ao acaso, sendo analisadas. Cobertura total ou parcial de selante foi observada para 274 de 275 dentes avaliadas aos 6 meses e para 199 avaliados aos 12 meses. Não houve diferença estatisticamente significante na permanência entre os dois selantes entre 6 e 12 meses. A liberação de flúor foi intensa, mas de curta duração. O conteúdo médio de flúor em toda saliva foi de 2,9 ppm + 0,13 (S.E), sendo o conteúdo na saliva da região selada de 11,4ppm + 1.0.2, retornando aos níveis iniciais dentro de 24 horas. Foi concluído que o acréscimo de flúor não diminuiu a efetividade do selante Fluroshield. Critério utilizado para avaliação do selante:

A - selante cobrindo a superfície oclusal, lingual ou vestibular do selante,

B - apenas uma cicatrícula é descoberta,

C - mais do que uma cicatrículas está descoberta,

D - não é detectável mais o selante.

Estudos "in vivo" e "in vitro", COOLEY et al. ${ }^{77}$, em 1990, JENSEN et al. ${ }^{176}$, em 1990, foram realizados para avaliar a liberação de flúor de materiais com adição deste. Em ambos estudos, a liberação de flúor foi rápida. O estudo "in vitro" mostrou uma liberação maior de flúor nos primeiros 2 dias. O estudo "in vivo" mostrou concentrações de flúor na saliva no mesmo lado do selante, no lado oposto e na boca toda (JENSEN; BILINGS; FEATHERSTONE ${ }^{175}$, 1990). A concentração de flúor em toda saliva aumentou significantemente dentro de 30 minutos após a aplicação do selante, mas retornou a níveis básicos dentro de 1 ou 2 dias. Da mesma forma, a concentração de flúor no lado oposto da boca era inicialmente alta e voltava 
a normalidade em 1 ou 2 dias. Deste modo, concluiram que o selante com flúor não proporcionaria nenhum efeito de longa duração para liberação de flúor.

Em 1990 MEJARE; MJOR ${ }^{223}$ comparando a permanência dos selantes resinosos, Concise e Delton, com o selante ionomérico convencional, Fuji III, verificaram uma supremacia de comportamento clínico quanto à permanência para os selantes resinosos, após cinco anos de análise clínica, possivelmente pelo fato da união mecânica apresentada pelos selantes resinosos, ser mais efetiva com o esmalte condicionado, que a união química, obtida com o selante ionomérico.

CARVALHO et al..$^{65}$, em 1990, afirmaram que o conteúdo de flúor nos dentes e sua relação com a experiência de cárie dos indivíduos são controversos na literatura e que vários autores falharam em demonstrar tal relação, pois o desenvolvimento da cárie depende de vários fatores difíceis de serem controlados, tais como dieta, higiene oral, suplementação de flúor etc., e não somente do conteúdo de flúor no dente; portanto,torna-se impossível definir a quantia mínima de flúor que seria necessária para se obter uma máxima proteção contra as cáries.

BRUNN; GIVAKOV50, em 1991, com estudos laboratoriais que compararam a quantidade de fluoreto de cálcio precipitado sobre superfícies hígidas e nas superfícies com lesões iniciais mostraram que uma quantidade significativamente maior de fluoreto de cálcio é formada nessas últimas. Esses dados indicam que o sal de fluoreto de cálcio pode permanecer dentro dos microporos das lesões e aí servir como um reservatório de flúor durante um considerável período de tempo. Os produtos de uso profissional são de alta concentração e baixa freqüência de aplicação enquanto que aqueles de auto-aplicação são de baixa concentração e alta freqüência. Os produtos de aplicação profissional mais comumente utilizados são solução neutra de fluoreto de sódio $2 \%(\mathrm{NaF})$; gel de fluorfosfato de sódio acidulado 1,23\% F (APF); verniz de fluoreto de sódio, 22,6 mgF/ml (NaF). Investigações clínicas sobre o efeito dos diferentes produtos, de aplicação profissional, na redução de cárie mostraram resultados semelhantes. 
Com o propósito de avaliar os efeitos de um selante com flúor e de um cimento de ionômero de vidro no início e sua progressão de lesões de cárie de esmalte. HICKS; FLAITZ ${ }^{157}$, em 1992, analisaram ao microscópio de luz polimerizada, a formação de lesões incipientes de cárie ao redor de preparos de classe $\mathrm{V}$ restaurados com um selante com flúor (Fluroshield) e um ionômero de vidro (Ketac-fil) e um selante convencional (Prisma Shield). A profundidade de lesão superficial foi significantemente reduzida tanto no grupo do selante com flúor como no ionômero de vidro quando comparados com o selante convencional. Concluíram os autores que um material odontológico contendo flúor em sua estrutura, quando colocado adjacente à superfície dental, poderá fornecer maior resistência ao início e à progressão das lesões de cárie.

TURPIN-MAIR; RAWLS ${ }^{351}$, em 1992, testaram um novo compósito e selante liberadores de flúor, "in vitro", em relação à homogeneidade, adaptação cavitária, microinfiltração e seu efeito na prevenção de um ataque artificial de cárie. Quarenta cavidades ao longo da fossa central de molares humanos foram preparadas. Vinte dentes foram restaurados com resina e selante encontrado comercialmente (Concise) e os outros vinte com a resina e selante experimentais. Os espécimes foram submetidos a vários testes para avaliação das propriedades clínicas propostas. Os resultados mostraram que em comparação com a resina composta comercial, a resina composta liberadora de flúor apresentou melhores propriedades no combate às cáries artificialmente induzidas, uniformidade de estrutura e menor infiltração após a termociclagem por 36 horas a $6-60^{\circ} \mathrm{C}$. Entretanto, não houve diferença estatisticamente significante na microinfiltração dos selantes após a termociclagem por 36 horas, nem após a estocagem por três meses a $37^{\circ} \mathrm{C}$.

CURY; SAAD ${ }^{83}$, em 1993, afirmaram que flúor importante na realidade, é aquele que está presente constantemente quando o dente está sujeito aos fenômenos de Desmineralização (DES-) e Remineralização (RE-), inibindo o primeiro ativando o segundo, e desta maneira, mantendo o equilíbrio de mineral das estruturas dentárias.

A adição de fluoretos para os selantes, de acordo com RIPA ${ }^{272}$, em 1993, veio para somar ao método preventivo. O flúor na saliva é rapidamente 
liberado, a partir do selante, no entanto, de acordo com esse mesmo autor são necessários estudos outros para determinar se a adição de flúor melhora a inibição de cárie. Há estudos sobre adição de fluoretos em selantes há mais de 15 anos. Basicamente são utilizados 2 métodos para incorporação de fluoretos no selante: 1-Após a aplicação do selante no dente, o sal é devolvido e os íons flúor são liberados; 2- O outro método envolve um componente fluoreto orgânico, que é unido quimicamente a resina, sendo que o fluoreto é liberado pela troca com outros íons.

Com a intenção de comparar a permanência e o efeito anticariogênico do selante de fissura ionomérico Fuji III e o selante resinoso fotopolimerizável Delton, FORSS; SAARNI; SEPPA ${ }^{116}$, em 1994, realizaram um estudo, onde aplicaram os selantes em molares permanentes de 166 crianças, com idades de 5 a 14 anos. Os selantes foram colocados nos dois lados da boca, sendo que cada lado correspondia a um selante diferente. Foram aplicados por três dentistas. Após dois anos avaliaram clinicamente, encontrando $26 \%$ de selantes ionoméricos e $82 \%$ de selantes resinosos totalmente retidos. Mesmo os resultados mostrando que a permanência do selante ionomérico foi menor que a do selante resinoso, não houve aumento de cárie, devendo-se isto às propriedades preventivas do material ionomérico.

PALMA et al. ${ }^{247}$, em 1994 realizaram estudo para a avaliação clínica dos teores de flúor liberados por um selante fluoretado. $O$ intuito desta investigação foi quantificar e qualificar a liberação de flúor de um selante fluoretado, o Fluroshield.Participaram 21 crianças de uma escola municipal da cidade de Bauru- SP, com idade entre 7 e 8 anos, com baixa prevalência de cárie e com os primeiros molares permanentes livres de cárie. Os primeiros molares foram selados com o selante fluoretado, seguindo as especificações do fabricante. A saliva foi coletada imediatamente após o selamento e após intervalos de uma e duas semanas, para posterior análise de teores de flúor presente. Observaram que houve uma ótima liberação de flúor na primeira hora (1,06 ppm F); após uma semana, os níveis de flúor na saliva decresceram de forma significativa $(0,232$ ppm F) e, após duas semanas, a medição dos níveis de flúor indicou valores muito próximos aos do grupo controle (sem aplicação do selante), sendo 0,161 ppm e 0,141 
ppm $F$, respectivamente. Através desses resultados, concluiram que 0 selante à base de resina fluoretado não é eficaz na liberação de flúor por períodos prolongados. Contudo, deve ser entendido como um método que faça parte de um conjunto de medidas preventivas. A utilização do selante tem-se mostrado eficaz na prevenção da cárie dentária em superfícies oclusais, o que é de grande importância pelas características de risco desse sítio dentário, segundo estes autores. Além disso, os efeitos benéficos do uso sistêmico e tópico do flúor manifestam-se com maior intensidade sobre as superfícies lisas dos dentes. PALMA et al. ${ }^{247}$, afirmaram também que, os resultados iniciais da avaliação clínica da liberação de flúor pelo selante Fluroshield, em períodos de tempo que variam de uma hora (coleta imediatamente após a aplicação) a duas semanas, demonstraram que a mesma ocorre com maior intensidade nos períodos iniciais, descrevendo gradativamente em função do tempo, atingindo, após duas semanas, níveis próximos aos do grupo controle, que não recebeu a aplicação do selante. A apresentação de baixos teores de flúor na saliva das crianças do grupo controle é entendida como reflexo do uso difundido de dentifrícios fluoretados e do uso de água de abastecimento fluoretada, comuns a todas as crianças avaliadas. PALMA et al. ${ }^{247}$, em 1994, colocaram ainda que, com o avanço nas pesquisas odontológicas, pode-se associar o selante, ao flúor dando assim maior proteção aos dentes, pois há o selamento da superfície oclusal promovido pelo selante, como também a liberação de flúor, protegendo, não apenas o dente selado, mas também as estruturas adjacentes.

Dentre os materiais utilizados nos pacientes com alto risco à cárie, os cimentos de ionômero de vidro vem se destacando por se tratar de um material que apresenta um bom desempenho clínico e laboratorial. Todavia, apresentam uma baixa resistência à compressão e a tração diametral. E quando comparados com as resinas compostas, apresentam menos poder de adesão a superfície do esmalte. Além de apresentarem poder anticariogênico, graças a liberação de íons flúor às estruturas dentárias adjacentes. Todavia não se conhece a quantidade de flúor liberado necessário à inibição de cárie (FORSS; SEPPA $\left.{ }^{115}, 1990\right)$.

A utilização de selantes vem sendo apontada como eficaz na prevenção de cáries de fossas, cicatrículas e fissuras. Mesmo após dez anos de sua 
aplicação, o elemento dentário selado tem se mantido livre de cárie, disseram RIPA; LESKE; VARMA ${ }^{275}$, em 1988. Este longo tempo de eficácia das superfícies seladas se deve, principalmente, à manutenção do agente selador intacto, segundo MANTON; MESSER ${ }^{212}$ (1995). O que se obtém graças a utilização de selantes com carga . Desta forma o uso de ionômero de vidro como agente selador é pouco indicado devido as suas propriedades retentivas serem pobres quando comparadas as dos selantes a base de BISGMA, para FORSS; SAARNI; SEPPA ${ }^{116}$ (1994), e o seu poder de penetração nas fossas e fissuras, promovendo o selamento, ser inferior quando comparado com os selantes resinosos. Porém a indicação do uso de selantes requer alguns procedimentos prévios, uma vez que para se obter uma ação eficaz do selamento, a superfície a ser selada deverá está completamente limpa e livre de cárie, CASTRO et al. ${ }^{66}$ (1991) e LLODRA et al. ${ }^{202}$ (1993).

Para REUTERVING; DIJKEN ${ }^{266}$, em 1995, o selamento oclusal constitui uma técnica reconhecidamente eficaz na prevenção da cárie dental e que, quando completado com aplicação de flúor, quer sistêmica ou tópica, tem levado à obtenção de excelentes resultados clínicos relativos à erradicação da cárie dental, com o esmalte protegendo as fossas, cicatrículas e fissuras e o flúor as superfícies lisas.

VONO; VONO; FIGUEIREDO ${ }^{361}$, em 1996, colocaram que o flúor, reduzindo o fenômeno de desmineralização e acelerando 0 de remineralização na dinâmica do desenvolvimento das lesões de cárie, confere uma grande proteção ao dente em termos de instalação e progresso da lesão. Contudo, áreas da superfície oclusal de molares e pré-molares, pela sua própria conformação morfológica, continuam sendo pontos críticos para o início de lesões de cárie. Inúmeras tentativas foram feitas para oferecer uma proteção à instalação da cárie nas fossas e fissuras de molares. Foi porém, com o emprego de selantes dentários, no início da década de 60 , que surgiu um método de prevenção da cárie oclusal, cuja eficácia vem sendo comprovada por inúmeros pesquisadores. Como, no entanto, os primeiros molares permanentes irrompem quase de uma maneira assintomática, sem serem notados pelos pais da criança, muitas vezes já existe cárie nas fossas desses dentes, quando são examinados pela primeira vez. Os selantes com 
adição de carga inorgânica, que melhora sua resistência ao desgaste, parecem apropriados para serem usados pela técnica invasiva. Seu baixo coeficiente de penetração impede um bom escoamento do selante nos sulcos e fissuras do dente, problema que é contornado quando essas estruturas são alargadas mecanicamente. Ainda, se o selante a ser usado possui flúor na sua composição, somam-se as suas propriedades preventivas. Vários estudos sobre a incorporação de flúor ao selante foram e estão sendo realizados. A diferença de comportamento clínico dos dois materiais estudados foi evidente, mostrando o selante um desempenho melhor, quanto aos aspectos observados. Embora, com o passar do tempo, o comportamento clínico do selante tenha piorado, sempre manteve-se superior ao do ionômero. A maior resistência ao desgaste, oferecida pelo Fluroshield, também se explica pela presença de carga de vidro de bário em sua composição. Quanto ao pior desempenho do ionômero isso era esperado, pois é sabido que falta-lhe resistência à abrasão e à fratura (MCLEAN; WILSON ${ }^{220}$, 1977) apresentando propriedades físicas inferiores às das resinas. O comportamento do selante e do ionômero não foi afetado pela posição do dente na boca, conforme puderam constatar. Os escores médios encontrados nos dentes com selante, bem como nos dentes com ionômero. As evidências permitiram afirmar que o emprego do selante resinoso Fluroshield, sobre pequenas preparações de sulcos e fissuras com lesões de cárie incipientes. A conclusão semelhante também chegou SIMONSEN ${ }^{306}$, 1980, usando o Concise, ao obter completa permanência nos $1^{\text {os }}$ molares superiores e $97,6 \%$ de permanência nos $1^{\text {ss }}$ molares inferiores, num total de 88 dentes selados pela técnica invasiva, após 3 anos de observação.

Pelo observado na pesquisa de VONO; VONO; FIGUEIREDO ${ }^{361}$, em 1996, pode-se dizer que nos primeiros 18 meses após o tratamento, também 0 ionômero foi eficaz como material de selamento de fossas e fissuras, pela técnica invasiva, apesar de ter sido constatada perda de volume oclusal do ionômero já no $6^{\circ}$ mês. Porém o ionômero de vidro mostrou uma tendência maior em acentuar perdas de material na margem que o selante, o que evidencia que o tratamento com aquele material permanece satisfatório por menos tempo que o efetuado com esse. Contudo a permanência do ionômero na cavidade bucal da criança pode ser prolongada, realizando-se uma reparação, quando necessária, através da colocação de nova porção de material 
sobre a superfície avariada. Este procedimento é simples, mas implica em novas sessões operatórias a intervalos regulares. Tais desvantagens fariam a prescrição do ionômero ser feita apenas pelo efeito cariostático do material. Também foi pesquisado, no trabalho, o aparecimento de cáries proximais nos molares tratados com ionômero e com selante, para se concluir sobre o efeito preventivo dessas lesões, exercido pelos diferentes materiais. Apenas 10 crianças apresentam cáries proximais reveladas por radiografias, ao longo de todo período experimental ( 2 anos). Aos 6 meses de observação foram detectadas 5 cáries, aos 12 meses 4 , aos 18 meses 2 e aos 24 meses 6 . Num total de 17 lesões encontradas em 984 faces examinadas, nove estavam em dentes selados com selante e 8 em dentes tratados com ionômero. Em 2 crianças, apenas os dentes selados com ionômero tinham cárie e em quatro crianças, foram apenas os dentes do grupo do selante que estavam com lesão. Já 4 crianças apresentaram cárie tanto em dentes com selante como com ionômero. Os molares inferiores tiveram mais cáries que os superiores e as faces mesiais foram mais afetadas que as distais em ambos os grupos tratados. Como a ocorrência de cárie foi mínima, pode-se dizer que ambos os materiais foram eficazes na manutenção de ausência de cárie na superfície proximal, usados como selantes pela técnica invasiva em molares permanentes.

Como se viu, não foi possível atribuirem um efeito preventivo maior ao selante ou ao ionômero, quanto a lesões de cáries proximais nos molares tratados. Quanto ao Fluroshield, a despeito de alguns trabalhos mostrarem que a liberação de fluoretos à partir dele é restrita a um período de tempo muito curto e a elevação de íons flúor na saliva, muito pequena, CURY; $\mathrm{SAAD}^{83}$, em 1993, afirmaram que ele libera concentrações de fluoreto significativas para o controle de desenvolvimento da cárie. Para finalizar, disseram VONO; VONO; FIGUEIREDO ${ }^{361}$, em 1996, que, com a intenção de preservar estrutura dentária sadia e evitar a ocorrência de cárie em molares permanentes jovens, com mínima ou questionável lesão de cárie nos sulcos e fissuras, estão indicados os selamentos com ionômero ou com selante resinoso. Contudo, esta técnica é apropriada apenas para situações onde o material não fica exposto a forças oclusais diretas. Uma restauração preventiva com materiais resistentes, oferece melhores resultados nos casos onde cáries mais extensas estejam presentes. Ainda, a técnica de selamento de fossas e fissuras deve ser acompanhada de outras medidas preventivas 
contra cárie dentária, como uso racional de fluoretos, controle na ingestão de hidratos de carbono fermentáveis e os processos adequados de higiene bucal.

KULA; WEBB; KULA ${ }^{193}$, em 1996, demonstraram que a exposição de selantes e resinas compostas fluoretada ao gel APF a 1,23\% resultava em deterioração da superfície do material quando visualizada no microscópio eletrônico de varredura. Esta deterioração da matriz da superfície poderia causar uma liberação subsequente de fluoretos perto da superfície, resultando em aumento da quantidade de flúor liberada.

REGO; ARAÚJO262, em 1996, realizaram uma avaliação clínica de selantes de fossas e fissuras, com e sem flúor, pelo período de dois anos. Aproximadamente metade das cáries em crianças e a maioria aos 15 anos de idade são cáries oclusais, disseram os autores, sendo este número reduzido com a aplicação de selantes. O objetivo do trabalho foi avaliar clinicamente eficiência e durabilidade de um selante com carga e flúor em dentes submetidos à ameloplastia e de selante sem carga e flúor aplicado sem uso da técnica invasiva. Foram aplicados 192 selantes fotoativados (109FluroShield e 83 Delton) em 166 dentes (pré-molares e molares de 39 pacientes, os quais foram avaliados após seis, 12, 18 e 24 meses. Nos controles realizados após seis e doze meses, os retornos foram de $100 \%$, aos 18 de 92,30 \%, enquanto aos 24 meses foi de 93,75\%, não ocorrendo a presença de cárie oclusal em todas as avaliações. Não ocorreram diferenças significativas no comportamento clínico entre o FluroShield e o Delton, nem também entre os selantes nas arcadas superior e inferior. Ambos selantes apresentaram permanência satisfatória após 24 meses da aplicação, com $1,92 \%$ de perda total para o FluroShield e 1,42\% para o Delton.

Afirmaram CARVALHO; MALTZ ${ }^{63}$, em 1997: sabe-se que, quanto maior a atividade cariogênica do paciente, mais intensivo deve ser o tratamento com flúor, em termos de freqüência e concentração.

STEINMETZ et al. ${ }^{322}$, em 1997, realizaram trabalho a partir de um estudo que avaliou a recarga e liberação de flúor de materiais restauradores, seguindo a seguinte proposta: avaliar a efetividade da exposição de materiais 
seladores com flúor ou resina composta ao meio de fluoreto gel fosfatado acidulado. Amostras foram feitas com selantes (Helioseal F, Ultraseal XT, Seal Rita-hour Viscosity and Seal Rita-regular Viscosity) e com 2 resinas compostas fluoretadas (Tetric e Heliomolar radiopaco), usando 1 matriz de Teflon. As espécimes foram divididas em 2 grupos: Grupo experimental: exposição em gel fluoreto fosfato acidulado a 1,23\%. Grupo controle: gel fosfato acidulado sem flúor. Colocadas em água deionizada e a concentração de flúor avaliada a cada 24 horas, no dia 7, os discos eram expostos aos gel durante 4 minutos e então lavados continualmente com água deionizada por 30 segundos. A concentração de flúor era medida após 7 dias. Resultados encontrados: aumento significante na quantidade de flúor na água após tratamento de todos os materiais com o gel fluoretado. Quantidade de flúor (liberação) na água maior para Tetric > Heliomolar > Helioseal > Ultraseal XI (para <0.01) e maior do que para os grupos controle. Não encontraram diferença estatisticamente significante entre grupos de 8 dias para os de 14 dias, para os materiais Seal Rita-Regular Viscosity e Seal Rita Viscosity. A liberação de flúor pelos selantes e resinas compostas após exposição das amostras a solução gel de flúor fosfato acidulado a 1,23\% mostrou resultados semelhantes àqueles para o cimento de ionômero de vidro após exposição a fluoreto de sódio a $2 \%$. Decorreu uma liberação maior de flúor um dia após a exposição ao fluoreto e um declínio no segundo dia após exposição. As liberações de flúor acumuladas revelaram que a exposição das amostras ao gel APF (flúor fosfato acidulado) a 1,23\% aumentou significantemente a quantidade de flúor liberada pela maioria dos materiais avaliados. $O$ aumento na liberação de flúor pode aumentar a absorção pelo esmalte adjacente, o que resulta em uma menor incidência de cárie na junção amelo-dentinária.

AMENDOLA; BORGES; ARAÚJO4, em 1997, em estudo "in vitro" verificaram a liberação de flúor de: a) um cimento de ionômero de vidro (Chellon-Fil-ESPB) e dois selantes (FluroShield-Dentsply e Alpha Fluor SealDFL) e b) os mesmos materiais após exposição a gel de flúor fosfato acidulado (FPA) a 1,23 por cento e gel de flúor neutro (FN) a 2 por cento.

Os espécimes foram colocados em tubos com água deionizada por 14 dias (etapa 1). Em intervalos de 24 horas, os espécimes eram transferidos para novos tubos com água deionizada e a quantidade de flúor era medida 
com eletrodo específico e registrada em ppm. Após este período, os espécimes foram divididos em três grupos, e o primeiro grupo foi exposto a gel de FPA por 4 minutos; o segundo grupo, a gel de FN por 4 minutos e o terceiro grupo foi tomado como controle. Em seguida, os espécimes foram lavados e transferidos para novos tubos contendo água deionizada em intervalos de 24 horas por mais 14 dias (etapa 2). O Chellon-Fil liberou significativamente maior quantidade de flúor que os selantes resinosos. Após a exposição dos espécimes aos géis fluoretados, houve significativamente maior liberação de flúor destes quando comparado ao grupo controle. Para o Chellon-Fil houve maior liberação de flúor após a exposição ao flúor fosfato acidulado comparado ao flúor neutro; já para os selantes não houve diferença estatística entre os dois géis. Os dados obtidos permitiram concluir que houve incorporação de flúor pelos materiais e subseqüente liberação após exposição a géis fluoretados, fazendo que estes materiais funcionem como reservatórios de flúor.

TOSTES ${ }^{349}$, em 1997, avaliando a prevenção de cárie de sulcos, fossas, cicatrículas e fissuras em dentes permanentes com diferentes materiais contendo fluoreto realizou trabalho de pesquisa que teve como principal objetivo verificar se haveria necessidade de tratamento adicional nessas superfícies em pacientes que participam do programa preventivo pré estabelecido. Foram selecionadas 25 crianças com quatro molares permanentes recém-irrompidos. Cada dente, escolhido por sorteio, recebeu um tipo de tratamento diferente. Um molar foi selado com cimento ionômero de vidro Ketac Cem (CIV), outro com selante resinoso contendo fluoreto (Fluroshield), o terceiro com verniz (Durafluor), e o último não recebeu tratamento (controle). Os molares foram avaliados a cada seis meses quanto à perda do material aplicado e ocorrência de cárie. Com relação à perda do material no grupo do Fluroshield, 41,3 porcento, 41,3 porcento e 36,3 porcento estavam totalmente retidos em seis, 12 e 24 meses, respectivamente. No grupo do CIV, o grau de permanência foi menor, sendo de 31,3 porcento e 13,1 porcento, aos seis e 12 meses. Aos 24 meses, nenhum dente apresentou permanência total. Não houve diferença significativa entre os grupos estudados com relação à cárie, sendo encontrada uma incidência de 7,95 porcento nos dentes avaliados. O grupo com incidência menor foi o do Fluroshield, com 1,13 porcento, seguido dos outros três grupos, com 2,27 porcento (X2=0,46ns;p>0,05) . 
CARVALHO; MALTZ ${ }^{63}$, em 1997, afirmaram que durante muito tempo o tratamento da doença cárie foi baseado em procedimentos restauradores de cavidades nas superfícies dentárias, contudo, o benefício limitado do tratamento restaurador em si fez com que os pesquisadores reconsiderassem os procedimentos convencionais, até então utilizados, para o diagnóstico e tratamento dessa doença. Essa reconsideração foi acompanhada de inúmeras pesquisas que levaram a um entendimento mais profundo sobre iniciação, desenvolvimento e estacionamento da doença cárie a nível subclínico e clínico. Consequentemente, os conceitos vigentes foram renovados, o diagnóstico aperfeiçoado e o tratamento tornou-se mais biologicamente orientado. O procedimento restaurador tornou-se parte de um tratamento mais abrangente direcionado para o controle da doença que é baseado na aplicação do conhecimento atual sobre o fator etiológico primário da doença, seus fatores determinantes e modificadores. Por outro lado, o conceito de prevenção da doença tem sido objeto de discussão devido a uma compreensão mais ampla do mecanismo de ação das medidas utilizadas. Atualmente, sabe-se que essas medidas interferem nos processos de desmineralização do tecido dentário ocasionando um equilíbrio ou uma diminuição da velocidade de progressão da doença de modo que seus sinais permanecem, para um grande número de indivíduos ou de superfícies dentárias, a nível subclínico. No tratamento tradicional da doença cárie os procedimentos eram associados à instrução sobre auto cuidado bucal, aplicações tópicas de flúor e proibição do consumo de sacarose de maneira padronizada para todos os indivíduos. O tratamento odontológico atual é individualizado, baseado na avaliação do caso e determinação da atividade de doença. A escolha do material restaurador, o tipo de tratamento com flúor, o aconselhamento dietético, o tratamento antimicrobiano e a delegação ou não de tarefas vai depender do diagnóstico da atividade de doença e da motivação do paciente em controlar a doença. No tratamento da doença cárie, as autoras afirmaram ser importante considerar que:

- a cárie dentária é uma doença crônica sendo portanto, de longa duração e progressão lenta para a maioria dos indivíduos de uma população. Esse padrão pode ser modificado em indivíduos com alta atividade de cárie nos quais a velocidade de progressão da doença aumenta sensivelmente;

- a utilização de medidas eficazes de controle faz com que se estabeleça um equilíbrio entre o processo de des/remineralização do tecido dentário 
que impede a progressão da doença. A doença pode ser estagnada em qualquer estágio de desenvolvimento; desde lesões ativas subclínicas até lesões ativas com cavidades.

$\mathrm{Na}$ seleção de medidas eficazes de controle é relevante estimar a viabilidade econômica e a possibilidade de implementação de acordo com a prevalência da doença na população. Tradicionalmente os programas de saúde bucal tem como rotina aplicação tópicas de flúor e selante como componentes da profilaxia básica da doença cárie. Nos programas mais recentes a aplicação tópicas de flúor como medida profilática, para populações de baixa prevalência de cárie, é recomendada para certos grupos de risco. A adoção dessa filosofia de tratamento tem sido gradual e é apoiada por países que possuem um serviço odontológico infantil gratuito e uma baixa prevalência da doença. Em locais onde a prevalência de cárie é elevada e a distribuição da doença segue uma curva normal, o uso de métodos alternativos de aplicação tópica de flúor deve ser considerado para toda a população. É importante ter em mente que, procedimentos adicionais serão necessários para um pequeno grupo de indivíduos para os quais a profilaxia básica não será suficiente.

TERADA et al. ${ }^{343}$, em 1998, apresentaram trabalho que teve como objetivo verificar em laboratório a liberação de flúor de cimentos de ionômero de vidro e outros materiais que contêm flúor após diferentes períodos de armazenagem. Para a avaliação da liberação de flúor, foram testados quatro cimentos de ionômero de vidro convencionais, uma resina composta e um selante de cicatrículas e fissuras. A avaliação da liberação de flúor foi feita em três períodos: 24 horas, 7 dias e 28 dias. Os resultados obtidos foram avaliados estatisticamente aplicando-se os testes ANOVA (análise de variância a um critério), para estudar a existência de diferenças entre os materiais dentro de cada intervalo de tempo de cada período testado, e o teste de Student Newman-Keuls, para avaliar onde estavam localizadas essas diferenças, ambos no nível de significância de 5\%. Todos os materiais testados liberaram quantidades significantes de flúor na forma em que foi conduzido o experimento. No período de 24 horas, houve diferença estatisticamente significante entre os materiais, sendo que VR liberou mais flúor do que todos os outros e, em ordem decrescente, CF, FJ, 
CS, FS e HE. Após 6 horas, o VR liberou 1,59 $( \pm 0,19) \mathrm{mgF}-/ \mathrm{mm} 2$. Ao final de 24 horas, liberou 0,26 $( \pm 0,03) \mathrm{m} \mathrm{gF}-/ \mathrm{mm} 2$. Nos mesmos intervalos, o HE

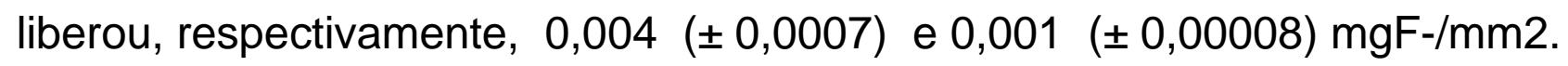
Observou-se que existe uma liberação inicial acentuada nas primeiras horas chamada "efeito explosão". Em seguida, para todos os materiais, verificou-se uma queda brusca nas taxas de liberação entre o primeiro e o segundo intervalo. Continuando TERADA et al. ${ }^{323}$, disseram que estudos in vitro e "in vivo" têm demonstrado que a presença do flúor ao redor das restaurações com materiais fluoretados diminui a desmineralização (HICKS; SILVERSTONE ${ }^{158}$, 1982; FORSS; SEPPA ${ }^{114}$, 1990) e aumenta a remineralização (FORSS; SEPPA ${ }^{115}$, 1990; FORSTEN ${ }^{118}$, 1990). Além de interferir no processo de des/remineralização do esmalte, o flúor liberado pelos cimentos de ionômero de vidro atua também na ecologia da microbiota bucal (SCHERER et al. ${ }^{294}$, 1989; KOCH; HATIBOVICKOFFMAN ${ }^{185}$, 1990; MCCOURT; COOLEY; HUDDLESTON ${ }^{216}$, 1990; FORSS et al. $\left.{ }^{117}, 1991\right)$, mesmo em situações de alto risco de cárie.

Entretanto, alguns trabalhos questionam se os cimentos de ionômero de vidro podem manter uma concentração de flúor elevada que possa influir na composição microbiana da placa por períodos de tempo prolongados ( SVANBERG et al. ${ }^{335}, 1990$ ). Por exemplo, VAN DIJKEN et al. ${ }^{354}$, em 1991, não observaram diferenças significantes no número de bactérias da placa que recobria restaurações de cimentos de ionômero de vidro, esmalte ou restaurações de resina composta realizadas há um ano. 
3 - PROPOSIÇÃO 


\section{3 - ProposiçÃo}

Com base nas hipóteses aventadas na introdução e na revista da literatura, foi proposto:

1 - verificar o grau de permanência do selante fotopolimerizável (Fluroshield) em dois grupos experimentais, após uma única aplicação: o primeiro, aplicando somente o selante e, o segundo, realizando a associação do selante com posterior aplicação tópica de flúor, assim que terminado o selamento. As avaliações foram feitas após 1 semana, 6 meses e 12 meses;

2 - verificar os benefícios oferecidos ou não, pela técnica proposta, associação selante/ flúor tópico, aos indivíduos pertencentes ao grupo de estudo, com idade entre 8 e 15 anos. 
4 - Materiais e Métodos 


\section{4 - Materiais e Métodos}

Este estudo foi realizado na Clínica Odontológica Acadêmica da Universidade do Sagrado Coração no período de agosto a dezembro de 1997.

Após avaliações clínica e radiográfica foram selecionadas 60 crianças, com idade entre 8 e 15 anos, que possuíam $1^{\text {os }}$ ou $2^{\text {os }}$ molares permanentes inferiores com indicação para a aplicação de selantes oclusais.

A seleção dos pacientes obedeceu aos seguintes critérios:

- apresentar alta suscetibillidade à cárie;

- ser de naturalidade bauruense e ter sempre residido na cidade de Bauru;

- total irrompimento do dente a ser selado molares recém irrompidos, com dificuldade em se realizar isolamento absoluto, foram descartados;

- ausência de cárie e de alterações de cor ou pigmentação ao redor das cicatrículas, fossas e fissuras;

- dentes sem evidência radiográfica de cáries interproximal e/ou oclusal (todos os dentes pertencentes aos grupos de estudo foram radiografados pela técnica radiográfica interproximal).

Foram selecionados 60 dentes para receber a aplicação do selante e o diagnóstico de higidez foi realizado através de inspeção tátil visual, com sonda exploradora no 5 (Duflex).

Foi utilizado o selante Fluroshield (Caulk/Dentsply,Milford), o qual se apresenta comercialmente em um "Kit" contendo gel ácido fosfórico a 50\%, duas bisnagas com a resina e pincel para a aplicação. Sua formulação apresenta uma resina fotopolimerizável (uma formulação modificada de BisGMA e uretano dimetacrilato diluído), contendo $50 \%$ de carga inorgânica e $2 \%$ de fluoreto de sódio em peso.

Este material apresenta cor branca opaca, que facilita a sua aplicação e sua permanência nas reavaliações (WAGGONER; SIEGAL $\left.{ }^{364}, 1996\right)$. Um outro fator é sua baixa viscosidade. Além disso, a presença de carga de vidro de bário, correspondente à parte inorgânica do material irá conferir-lhe melhor resistência mecânica e ao desgaste (MENAKER ${ }^{224}$, 1984; STACH $\left.{ }^{317}, 1992\right)$.

\subsection{Técnica de Aplicação}


Importante salientar que todos os procedimentos foram realizados por um mesmo operador, o qual obteve o termo de consentimento devidamente assinado pelos pais ou responsáveis dos pacientes, autorizando a participação destes no presente estudo.

A efetividade do selante está diretamente relacionada ao rigor da técnica aplicada. Portanto, a realização de todas as etapas e a fidelidade em suas aplicações são fatores fundamentais para o sucesso clínico deste procedimento.

Em cada um dos pacientes foi realizado o selamento com Fluroshield (Caulk/Dentsply, Milford) em um molar permanente inferior, selecionado segundo critérios anteriormente citados.

A amostra de pacientes foi dividida em 2 grupos, os quais foram especificados na Tabela 1.

Tabela 1 - Grupos de estudo

\begin{tabular}{c|c|c|c|c}
\hline Grupo & Material & Fabricante & $\begin{array}{c}\text { Tipo de } \\
\text { Polimerizaçã }\end{array}$ & $\begin{array}{c}\text { Aplicação tópica } \\
\text { flúor }\end{array}$ \\
\hline A & Fluroshield & Dentsply & Física & Sim \\
\hline B & Fluroshield & Dentsply & Física & Não \\
\hline
\end{tabular}

Após a completa polimerização do selante oclusal, os dentes do grupo A receberam aplicação do flúor fosfato acidulado a 1,23\% em forma de gel (Odachan), durante 5 minutos, antes da remoção do isolamento absoluto.

Esta aplicação foi realizada conforme técnica padronizada por BRUDEVOLD ${ }^{48}$ (1963), baseada na existência de interferências do halogênio flúor quando combinado com a hidroxiapatita do esmalte, sobre a retentividade dos selantes (BUONOCORE ${ }^{52}$, 1963 ; SHEYKOLESLAM et al. ${ }^{298}$, 1972; LOW et al. ${ }^{206}$, 1975; TAKAHASHI et al. ${ }^{339}, 1980$ ).

Após remoção do isolamento, foi solicitado ao paciente que não se alimentasse no mínimo durante 60 minutos. 


\subsection{Sequência clínica}

Foi realizada a seguinte sequência clínica, segundo SILVERSTONE ${ }^{303}$, 1982.

\section{1'. etapa:}

Os dentes receberam profilaxia com $\mathrm{H}_{2} \mathrm{O}_{2}$ a $3 \%$, para remover resíduos orgânicos das superfícies oclusais, com auxílio de uma escova tipo Robinson. Depois, foram lavados com "spray" água-ar por 60 segundos.

O uso da água oxigenada a $3 \%$ em Odontologia de modo geral se baseia em sua capacidade de liberar oxigênio, modificando o meio de proliferação bacteriana (especialmente de bactérias anaeróbicas), e ainda de deslocar partículas orgânicas e inorgânicas (VIEIRA ${ }^{359}$, 1993).

\section{2a. etapa:}

Isolamento absoluto do campo operatório, com dique de borracha. Segundo RIPA ${ }^{269}$, em 1980, e RIPA ${ }^{272}$,em 1993, a necessidade de um campo operatório estritamente seco sugere que o uso do dique de borracha aumentaria o sucesso do selante.

\section{3a. etapa:}

Foi realizado o condicionamento ácido do esmalte, com solução de ácido fosfórico gel a $50 \%$ (fornecida pelo fabricante), aplicada com um pincel durante 60 segundos, restringindo-se aos sulcos e fissuras propriamente ditos, não invadindo os planos inclinados das cúspides, como indicam as instruções do produto, evitando assim a presença de contatos prematuros. Foi recomendado a aplicação da solução na superfície oclusal com o pincel, por algumas vezes, para melhorar a dissolução dos prismas de esmalte.

\section{4a. etapa:}

Lavagem abundante com "spray" água-ar durante 60 segundos, para garantir a remoção do gel e dos produtos de reação. Para este procedimento utiliza-se o sugador de alta potência. BARKMEIER ${ }^{22}$ et al., em 1986, concluíram que a lavagem do esmalte por 60 segundos ao invés de 15 
segundos aumentava significativamente a força de união do selante. $O$ condicionamento do esmalte com ácido fosfórico resulta numa deposição de fosfatos de cálcio, os quais devem ser removidos para proporcionar uma ótima adesão, fato também afirmado por WILLIAMS; VON FRAUNHOFER ${ }^{373}$, em 1977.

\section{5a.etapa:}

Logo após foi realizada a secagem com jatos de ar. $\mathrm{O}$ ar comprimido utilizado é obtido através de uma mistura de oxigênio e nitrogênio, num processo patenteado pela White Martins e, por ser uma mistura de ar pura, é estéril e livre de resíduos de óleo e água.

\section{6. etapa:}

Aplicação do selante nas superfícies do dente condicionadas, utilizando um pincel fornecido pelo fabricante. Neste estágio, foi essencial evitar qualquer contaminação da superfície condicionada pela saliva, que poderia acarretar uma união pobre ou até mesmo uma ausência de união do selante ao esmalte.

\section{7a. etapa:}

Aplicação da fonte de luz halógena para fotopolimerização do selante, com aparelho da Primelite (Dentsply, Rio de Janeiro), com potência de $500 \mathrm{~mW} / \mathrm{cm} 2$ por 60 segundos, tendo sido mantido a distância aproximada de $1 \mathrm{~mm}$ da superfície a ser selada.

Antes de iniciar a fotopolimerização do selante, esperou-se o tempo de 10 segundos após sua aplicação no interior do sulco, para que este tivesse um período maior para escoar e assentar-se bem nas superfícies de esmalte, contribuindo assim para uma satisfatória penetração no esmalte dental condicionado, apesar da presença de carga em sua composição. Este procedimento está de acordo com estudo de CHOSACK; EIDELMAN ${ }^{74}, 1988$, que concluíram que não é conveniente iniciar a polimerização de um selante imediatamente após sua aplicação, o que impediria sua adequada penetração nos microporos do esmalte dental condicionado, fato esse de extrema relevância para a obtenção de uma permanência mecânica satisfatória. 


\section{8. etapa:}

Exploração da superfície selada com sonda exploradora nำ 5 (Duflex). As cicatrículas, fossas e fissuras deviam estar completamente cobertos. Se houvesse alguma falha, nova porção de selante era aplicada. Além disto, era verificada a presença de bolhas na camada de selante, as quais, se presentes eram eliminadas com a reaplicação.

A presença de contato prematuro pode também facilitar a perda do selante. Porisso era realizada avaliação da oclusão com papel carbono. Os contatos prematuros existentes eram eliminados com broca 12 lâminas (Komet, Alemanha), girando em baixa-rotação.

\subsection{Avaliação}

Os dois grupos de dentes selados pertencentes ao estudo, Grupo A, onde imediatamente após o selamento e antes da remoção do isolamento absoluto foi aplicado fluor gel fosfatado acidulado por um tempo de 5 minutos, e Grupo B em que, após o selamento não foi aplicado o flúor, passaram por quatro avaliações respectivamente: imediatamente e após, uma semana, 6 e 12 meses.

Todas as avaliações foram realizadas por um avaliador, através de exame tátil-visual, com sonda exploradora no 5 (Duflex), espelho clínico nำ1 (Duflex), luz artificial e isolamento relativo. Anteriormente às avaliações, os dentes eram submetidos à lavagem e secagem com jatos de água e ar da seringa tríplice.

$1^{a}$ Avaliação: Imediatamente após a polimerização do material. Diante da presença de falhas, era realizada uma reaplicação, sendo o paciente só liberado após certificação da efetividade do selamento.

$2^{a}$ Avaliação: Uma semana após.

$3^{a}$ Avaliação: Realizada após 6 meses.

$4^{a}$ avaliação: Realizada após 12 meses.

Em todas as avaliações os dentes foram classificados segundo os critérios propostos, apresentados na Tabela 2. 
Tabela 2 - Critérios utilizados para a avaliação da permanência do selante

$$
\begin{aligned}
& \mathrm{PT}=\text { Presença Total } \\
& \mathrm{PP}=\text { Presença Parcial } \\
& \mathrm{A}=\text { Ausência }
\end{aligned}
$$

I- presença total: quando ao exame clínico, mediante explorador percorrendo todas as superfícies seladas, constatou-se que não havia perda do selante;

II- presença parcial: quando eram verificadas perdas do selante;

III- ausência: quando era verificada queda total do selante.

Os critérios utilizados para as avaliações periódicas foram os seguintes:

- presença total (PT), para os dentes que apresentavam (todos) os sulcos, fossas, cicatrículas e fissuras cobertos;

- presença parcial (PP), para que apresentavam parte dos sulcos, fossas, cicatrículas e fissuras descobertos;

- e ausência (A) quando nenhum selante podia ser visualizado nos sulcos, fossas, cicatrículas e fissuras dos dentes.

Ambos os grupos receberam, após a sessão de selamento oclusal, instruções sobre a doença cárie dental, fatores primários e predisponentes, higiene bucal e sua importância.

Diante de uma perda parcial ou mesmo total do selante, era realizada uma reaplicação, exatamente da mesma forma como aplicada pela primeira vez. 


$$
5 \text { - RESULTADOS }
$$




\section{5 - Resultados:}

Tabela 3: Resultados obtidos para as avaliações do dentes selados do grupo A, com aplicação de flúor

Pacientes

Dentes selados Avaliacão Avaliacão Avaliação atendidos 1 semana 6 meses 12 meses

L.F.D.

D.C.S.

N.D.F.

E.C.PS

C.A.SP

SAP

CMS

JAP

BDN

CAR

SDN

RBRM

IN

AP

$\mathrm{HL}$

DAM

LC

EDN

CAP

JAR

DAC

ERN

ARS

AS

KGP

AFSP

LGT

NGC

CGG

PHP

37

$\$ 7$

37

37

37

37
37

37

36

$\$ 7$

37

36

36

36

36

36

36

37

$\mathrm{P}$

PT

PT

PT

PT

PT

$\mathrm{PT}$

PT

PT

PT

PT

PT

PT

PT

\begin{tabular}{|c|c|c|c}
\hline 7 & PT & PT & PT \\
\hline
\end{tabular}

RT

PT PT

中T

PT

\begin{tabular}{|c|c|c}
\hline $\mathrm{PT}$ & $\mathrm{PT}$ & $\mathrm{PT}$ \\
\hline $\mathrm{PT}$ & $\mathrm{PT}$ & $\mathrm{PT}$ \\
\hline
\end{tabular}

PT $\quad$ PT

PT

PT

PT

PT

PT

PT

PT

PT

PT

PT

PT PT

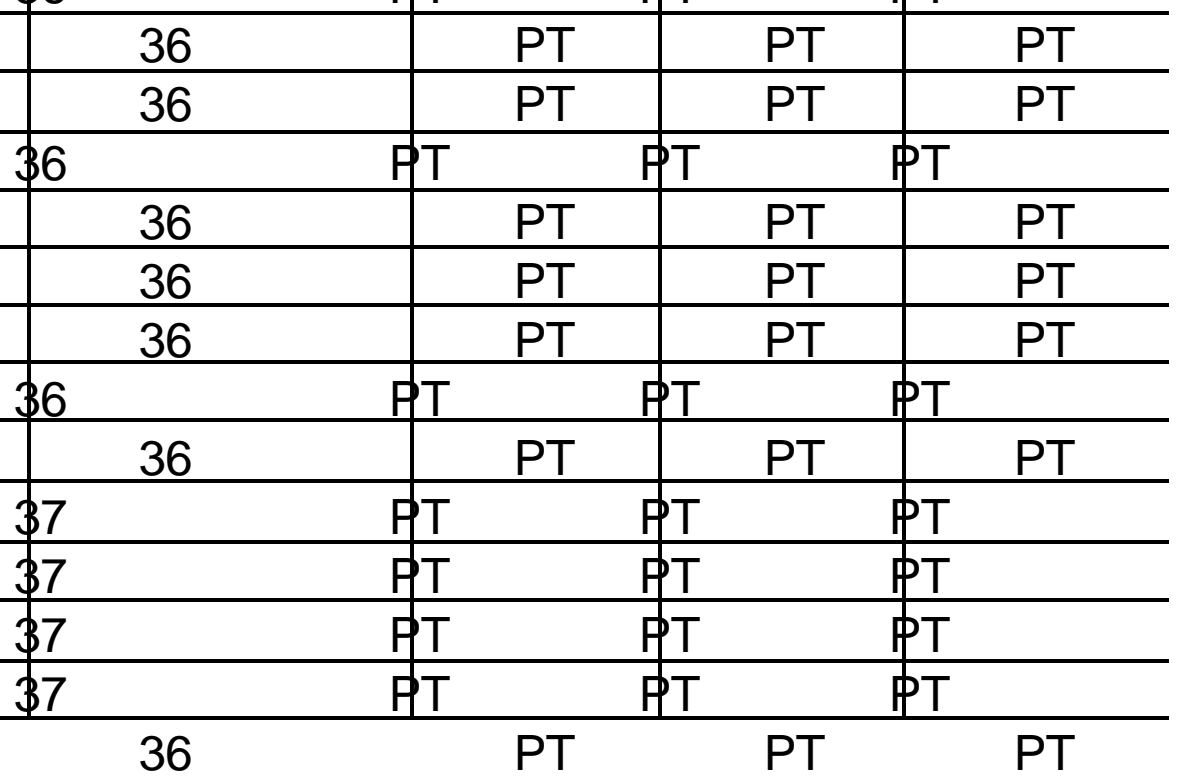

LEGENDA : PT - Presença Total; PP - Presença Parcial; A - Ausência 
Tabela 4: Resultados obtidos para as avaliações dos dentes selados no grupo B, sem aplicação de flúor

Pacientes
atendidos

$\mathrm{FB}$

VNS

KCA

RARM

$\mathrm{SBL}$

$\mathrm{HC}$

CFCS

GGP

AP

$\mathrm{HL}$

TA

$J A B$

DCA

ACZ

AAF

RGD

AS

HTP

$\mathrm{CCN}$

SES

ECBG

RCP

NEMJ

RBS

$M Z M$

ACFB

XES

ATB

WPC

BC

LEGENDA

Dentes selados Avaliagão Avaliação Avaliação

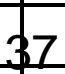

1 semana 6 meses 12 meses AT

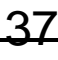

37

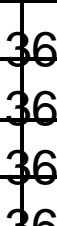

36

36

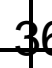

PT - Presença Total

PP - Presença Parcial

A - Ausência 
A análise estatística dos resultados foi realizada através do Teste de GOODMAN $^{136,136}(1964,1965)$ para contrastes entre e dentro de populações multinomiais, em nível de $5 \%$ de significância. Para os resultados obtidos nas avaliações de 1 semana e 6 meses não houve necessidade de se realizar a análise estatística, pelo fato da totalidade dos indivíduos terem apresentado $100 \%$ de presença total do selante aplicado.

A tabela 5 expressa os resultados da análise realizada para os resultados obtidos após avaliação de 12 meses.

\begin{tabular}{|c|c|c|c|c|}
\hline GRUPO & TOTAL & PARCIAL & AUSENTE & TOTAL \\
\hline Com flúor & 100,00 b.B. & 0,00 a.A. & 0,00 a.A. & 30 \\
\hline Sem flúor & 67,00 a.C. & $27,00 \quad$ b.B. & 6,00 a.A. & 30 \\
\hline
\end{tabular}

Letras minúsculas: usadas na comparação dos grupos, fixada a resposta da presença do selante.

Letras maiúsculas: usadas na comparação das respostas da presença do selante dentro do grupo.

Para a interpretação das letras, considera-se que duas proporções com uma mesma letra (minúsculas) não diferem entre si em nível de $5 \%$ de significância.

No grupo com flúor, houve predominância significante $(p<0,05)$ da presença total. No grupo sem flúor, houve predominância significante $(p<0,05)$ da presença parcial em relação à ausência do selante e também da presença total em relação a presença parcial e ausência do selante.

Conclusão da avaliação após 12 meses de aplicação:

Ausência de Selante : com flúor $=$ sem flúor

Presença Parcial : : com flúor < sem flúor

Presença Total : com flúor $>$ sem flúor

Com flúor: Total $>$ ( Ausência $=$ Parcial $)$

Sem flúor: Total > Parcial > Ausência 
Em relação à presença de novas lesões cariosas, estas não foram verificadas tanto na avaliação aos 6 meses como naquela realizada aos 12 meses onde, além do exame táctil-visual para verificação da presença de cáries, também realizaram-se radiografias interproximais dos dentes selados, pertencentes aos dois Grupos (A e B) e não se encontraram imagens radiográficas compatíveis com lesão cariosa presente 
6 - DISCUSSÃO 


\section{6 - DISCUSSÃO}

O processo carioso nas superfícies oclusais se inicia quase sempre pelo acúmulo de microrganismos e nutrientes dentro das fossas, sulcos, fissuras e cicatrículas. Fissuras com paredes íngremes e aberturas estreitas são particularmente suscetíveis. A delgada camada de esmalte na base das fissuras leva, usualmente, a um envolvimento dentinário precoce (NEWBRUN ${ }^{239}$,1990). Sabe-se que a alta freqüência de cáries oclusais em molares decíduos e permanentes e também em pré-molares, principalmente nos primeiros anos de exposição ao meio bucal, é resultante do metabolismo de bactérias cariogênicas, que encontram nos sulcos e fissuras um nicho com condições favoráveis para se desenvolverem (BOHANNAN, 1982 29 HOROWITZ ${ }^{160}$, 1982; ISSAO; ANDO ${ }^{172}$, 1983; FARIA et al. ${ }^{107}, 1999$ ).

Muitas tentativas foram realizadas no sentido de se combater, através de meios e métodos, este tipo de cárie.

A introdução da técnica de condicionamento do esmalte com ácido fosfórico, desenvolvida por BUONOCORE ${ }^{51,52}$ (1955; 1963), e pesquisas em torno de materiais resinosos, iniciadas por BOWEN na década de 60, abriram novos horizontes nas diversas especialidades da Odontologia (HEROLD ${ }^{156}$, 1990). A partir daí, o emprego dos selantes para sulcos, fossas, cicatrículas e fissuras tornou-se o método de eleição para prevenir cáries oclusais e sua efetividade é comprovada por um vasto número de pesquisas clínicas e com os resultados obtidos no presente trabalho.

De acordo com os resultados aqui obtidos, o selamento das áreas de sulcos, fissuras, cicatrículas e fossas oclusais mostrou-se efetivo e necessário, conforme afirma MENAKER ${ }^{224}$, em 1984, ao constatar que a suscetibilidade da superfície oclusal ao ataque pela cárie resulta da morfologia das fissuras e cicatrículas em fundo de saco. As fissuras oclusais consistem de falhas profundas e estreitas dos sulcos, que se estendem pela espessura do esmalte e propiciam um local ideal para a permanência de bactérias, restos alimentares e nutrientes. Uma vez que as fissuras apresentam uma largura de 
aproximadamente uma fração do diâmetro de uma cerda de escova dentária, a limpeza pelos métodos convencionais torna-se quase impossível; daí o ambiente propício que favorece a pronta ocorrência da cárie dentária.

A análise do conteúdo de cicatrículas e fissuras indica que estão preenchidas por restos alimentares e placa, constituída por uma variedade de microrganismos (THYLSTRUP ${ }^{344}$, 1988; POWELL ${ }^{254}, 1999$ ).

As vantagens dos selantes oclusais sugeridas na literatura são: aderem ao esmalte, obturando fisicamente sulcos, fossas, cicatrículas e fissuras por um período de um ano ou mais: não alteram a morfologia do dente; são inócuos aos tecidos bucais; requerem tempo de aplicação reduzido e polimerizam-se rapidamente. Além destas, a satisfação de ter uma boca livre de cárie e a ausência de desconforto, quando comparado aos procedimentos operatórios normais do preparo de cavidades, são outras vantagens elencadas pela $\mathrm{ADA}^{6}$, em 1984.

SIMONSEN ${ }^{315}$, em 1991, em estudo acompanhando selantes, encontrou um percentual de dentes que se apresentavam livres de cáries em 94\% com 5 anos de estudo, 84\% com 10 anos e $74 \%$ com 15 anos. O estudo conclui que o selamento é significantemente benéfico, já que reduz tratamentos custosos, causa pouco trauma ao paciente e ao longo do tempo poucas restaurações são colocadas e recolocadas. O estudo de SIMONSEN ${ }^{315}$ sugere que, em condições especiais, a prática do selamento de resina poderia prevenir $100 \%$ de cáries em fossas, cicatrículas e fissuras, o que foi confirmado pelos resultados alcançados neste trabalho.

Vários autores relataram trabalhos com controles realizados em 6 meses até 15 anos da aplicação de selantes oclusais, com resultados satisfatórios, entre eles podem-se citar os de: CUETO; BUONOCORE ${ }^{79}$, 1967; BUONOCORE ${ }^{55}$, 1975; WEYNE; CEZAR; GOMES ${ }^{371}$, 1977; CHARBENEAU; DENNISON $^{72}$, 1979; POULSEN et al. $^{253}$, 1979; ISLER; DOLINE ${ }^{170}, 1981$; RYGE; BASKO ${ }^{291}$, 1983; SIMONSEN ${ }^{310}$, 1987; DE CRAENE et al..$^{87}$, 1989; ROMCKE et al. ${ }^{290}$, 1990; MERTZ-FAIRHURST et al. ${ }^{229}$, 1991; RAADAL; UTIKILEN; NILSEN ${ }^{258}$, 1991; SIMONSEN ${ }^{315}$, 1991; SUNDFELD et al. ${ }^{332}$, 1994; FRANCO; MAGRO; CARVALHO ${ }^{119}$, 1994; SILVA; ARAÚJO; REGO ${ }^{299}, 1996$.

Os resultados deste trabalho concordam com os da literatura existente, já que o método foi efetivo na prevenção de cárie em $100 \%$ dos casos, onde 60 dentes de 60 pacientes foram selados e controlados pelo período de 12 
meses independentemente de aplicação posterior ou não tópica de flúor. Os selantes apresentaram total permanência após o período de 6 meses e foram capazes de impedir o desenvolvimento da lesão cariosa ou processo de desmineralização, daqueles órgãos dentários.

Como complemento do tratamento, todos os pacientes atendidos receberam instruções sobre técnicas de escovação e manutenção da higiene bucal.

Os resultados demonstraram 100\% de permanência dos selantes após 6 meses da aplicação em ambos os grupos, proporcionando um bom prognóstico para o $3^{\circ}$. controle, aos 12 meses, sabendo-se que o período de 6 meses é considerado crítico pela literatura.

BAGRAMIAN et al. ${ }^{19}$ (1979), corroborados por BASSO ${ }^{23}$ (1983), ISSAO; ANDO $^{172}$, (1983), e VALSECKI; VERTUAN ${ }^{353}$, (1988), concluiram que os maiores índices de perdas aos 6 meses de observação estão provavelmente relacionados a falhas associadas ao isolamento absoluto e ao condicionamento ácido do esmalte.

Pode-se observar a eficiência da técnica aplicada, quanto à permanência e prevenção de cáries, em ambos os grupos, A e B, como pode-se verificar nas tabelas I e II, onde a posterior aplicação de flúor tópico, não interferiu nos resultados aos 6 meses.

Aos 12 meses, o grupo A, com associação da aplicação tópica de flúor, apresentou $100 \%$ de permanência total dos selantes, enquanto o grupo $B$, em que foi aplicado apenas o selante Fluroshield, apresentou 67\% de permanência total dos selantes. Estes resultados estão de acordo com os relatados por REGO; ARAÚJO ${ }^{262}$, em 1996, os quais obtiveram $100 \%$ de permanência do selante Fluroshield, após 6 e 12 meses, quando era empregada a aplicação tópica de flúor gel por 5 minutos, antes da remoção do isolamento absoluto.

Os resultados do presente estudo, onde se verificaram excelentes porcentagens de permanência total dos selantes de cicatrículas e fissuras confirmam um dos primeiros estudos clínicos sobre esta técnica realizado em 1967 por CUETO; BUONOCORE ${ }^{79}$, no qual, depois de um ano, da aplicação de um esmalte adesivo para selar cicatrículas e fissuras de 601 molares e pré-molares livres de cáries sem preparação dos mesmos, resultou em uma redução de $86,3 \%$ de aparecimento de novas lesões cariosas 
comparada com um número similar nas áreas do controle em dentes nas mesmas bocas. Ao final dos 6 primeiros meses, $80,2 \%$ dos dentes tratados estavam completamente cobertos por selante, $15,3 \%$ parcialmente descobertos e apenas $4,5 \%$ completamente descobertos.

Ao final dos segundos 6 meses, depois de um novo tratamento, $71,2 \%$ dos dentes tratados estavam completamente cobertos, $19 \%$ parcialmente descobertos e $9,8 \%$ totalmente descobertos. A perda do selante de dentes tratados não aumentava sua suscetibilidade à cárie, a qual foi $71 \%$ menos que em controles depois de um ano.

Os valores de permanência dos selantes dos grupos A e B aplicados em molares permanentes podem ser aceitos como ótimos resultados, principalmente se apoiados na afirmação de vários autores como CUETO; BUONOCORE $^{79}$ (1967), ROCK ${ }^{278}$ (1972), de que o mais rigoroso teste de um selante para superfícies oclusais é sua permanência em molares por períodos prolongados. Um estudo clínico chave realizado por HOROWITZ; HEIFETZ; MCCUNE ${ }^{162}$, em 1974, mostrou que molares perdem selantes duas vezes mais que a taxa estabelecida para pré-molares.

MERTZ-FAIRHURST ${ }^{226}$, em 1984, relatou que é vantajoso utilizar um selante fotopolimerizável, devido à eliminação do processo de mistura (base com catalisador), podendo-se atenuar a incorporação de bolhas de ar na massa. Enfatizou ainda que os selantes são agentes preventivos da cárie dentária, efetivos e duráveis que o profissional pode usar em seus pacientes.

Através de uma análise clínica e fotográfica, os autores SUNDFELD et al. ${ }^{331}$, estudaram em 1992, a permanência de dois selantes na superfície oclusal, usando uma solução corante a base de hematoxilina. Após os 18 meses de análise verificaram-se que o material fotopolimerizável é o mais efetivo quanto à permanência e, consequentemente, permanece maior tempo na superfície oclusal e cumpre melhor a sua função preventiva da cárie dental do que o quimicamente polimerizável.

Em relação ao selante Fluroshield, o estudo de CAMLOFFSKI; MAZUREK $^{57}$, 1996, apresentou, aos 6 meses, 91,38\% de permanência completa, resultado superior ao de $82,2 \%$ de permanência total, encontrados por BERNARDES et al. ${ }^{25}$ (1994).

Após um ano, CAMLOFFSKI; MAZUREK ${ }^{57}, 1996$ obtiveram 86\% de permanência completa, $14 \%$ de permanência parcial e nenhuma perda total, 
resultado superior ao de $80 \%$ de permanência total encontrado por BERNARDES et al..$^{25}$ (1994), e inferior ao de $17,8 \%$ de permanência parcial e $2,2 \%$ de perda total encontrado pelos mesmos autores.

Os resultados de CAMLOFFSKI; MAZUREK, ${ }^{57}$ 1996, são diferentes dos deste estudo e dos de GWINNET $^{143}$ (1973), corroborado por GOING et al ${ }^{134}$. (1976), segundo os quais, mesmo em casos de perda parcial do selante, o esmalte na região das cicatrículas e fissuras continua protegido do ataque de cárie. CAMLOFFSKI; MAZUREK ${ }^{57}$, 1996, observaram a presença de cárie oclusal, em alguns molares com permanência parcial e perda total. Salientaram ainda esses autores a importância e a eficiência do uso do selante como parte de uma filosofia preventiva, associada a aplicações periódicas de flúor, instruções sobre higiene oral e controle da dieta, além de consultas para revisão, pois só assim o profissional estará promovendo a saúde bucal, objetivo maior da profissão.

Os selantes formam uma efetiva barreira física entre a superfície dos dentes e o meio bucal, protegendo o esmalte dos ácidos produzidos pelo metabolismo bacteriano, LEE ${ }^{194}$, 1974; MEDINICK; LOESCHE; CORPRON ${ }^{222}$, 1974; RIPA ${ }^{270}$, 1982; SIMONSEN ${ }^{308}$, 1982; VRBIC ${ }^{362}$, 1983; HUNT; KOROUT; BECK $^{166}$, 1984; BALL ${ }^{20}, 1986$; ISMAN; KIZER ${ }^{171}, 1987$; ALBERT $^{2}, 1999$.

A eficácia dos selantes está relacionada com sua permanência efetiva na superfície do esmalte, disseram os seguintes autores: GWINNETT ${ }^{141}$, 1971; RIPA ${ }^{272}$, 1985; WEINTRAUB; BURT ${ }^{366}$, 1987; SIMONSEN ${ }^{314}, 1991$.

Esta eficácia tem sido demonstrada por vários autores que foram categóricos ao afirmarem que os mesmos, enquanto intatos e retidos completamente, dão uma proteção de $100 \%$ às superfícies (ULVESTAD ${ }^{352}$, 1976; TONN; RYGE ${ }^{348}$, 1982; RYGE; BASKO ${ }^{291}$, 1983; ROCK ${ }^{282}, 1984$, SIMONSEN ${ }^{315}$, 1991; TRUHE ${ }^{350}$, 1991; REGO; ARAÚJO²62, 1996).

Considerando-se a permanência como a principal característica a ser avaliada, na efetividade dos selantes, os $100 \%$ de permanência total neste estudo, nos dois grupos aos 6 meses e $100 \%$ no grupo A e $67 \%$ no grupo B aos 12 meses, demonstraram ser um ótimo comportamento clínico.

O flúor é um agente efetivo para a prevenção da doença cárie, de acordo com vários autores podendo-se citar: ARNOLD et al. ${ }^{13}$, 1956; SYRRIST ${ }^{338}$, 1956; FORREST ${ }^{114}$, 1956; BACKER-DIRKS ${ }^{18}$, 1974; RIPA ${ }^{269}$, 1980; BRUNN; GIVASKOV $^{50}$, 1991; RIPA ${ }^{273}$, 1993; HOROWITZ ${ }^{161}$, 1995; BOWEN; TABAK ${ }^{38}$, 1995; WEYNE ${ }^{370}$, 1997; FERREIRA ${ }^{112}, 1998$. 
Podem-se observar também trabalhos como os de VAN DORP; TEN CATE ${ }^{355}$, que, em 1992, mostraram um comportamento superior do selante, quando comparados ao flúor, na proteção da superfície do esmalte de fossas, cicatrículas, sulcos e fissuras contra a desmineralização, proteção essa que perdura por todo tempo em que a película de selante se mantém íntegra, afirmação corroborada por BRAVO et al. ${ }^{42}$, em 1997.

Associado à metodologia preventiva dos tratamentos de cárie dentária, onde prevenir não deve ser encarado como a aplicação de um único método e sim de um conjunto de métodos atuando concomitante, e considerando que a boca é parte de um todo do indivíduo, onde cada interferência, por menor que seja, repercutirá em esferas de ordem física, psíquica e social do mesmo, foi realizado este estudo para avaliação do papel do selante oclusal e do flúor aplicado topicamente. Para tal, na esquematização da pesquisa, foram estabelecidos dois grupos experimentais, a saber: Grupo A, selante + fluoreto tópico e Grupo B, somente a colocação do selante.

O objetivo básico desta divisão foi o de verificar o efeito combinado do flúor mais selante, pois, anteriormente, RODER; SUNDRUM²8, em 1976, e SIMONSEN ${ }^{306}$, em 1980, mostraram que a aplicação de selante em crianças residentes em áreas com água fluoretada apresentavam um grau de permanência maior que aquelas residentes em região com água não fluoretada. Por outro lado,outros autores dedicaram uma atenção especial ao flúor, relacionando-o como um dos fatores que interferem na permanência do selante; entre eles SHEYHOLESLAM; HOUPT ${ }^{297}$, 1978; RANTALA ${ }^{260}$, 1979; DUARTE ${ }^{99}$, 1985; DUARTE; ISSAO ${ }^{100}, 1987$; KOH et al. ${ }^{187}, 1995$.

Atualmente os selantes oclusais apresentam resultados clínicos satisfatórios e são utilizados com sucesso na prevenção de cáries dentárias nas áreas retentivas das superfícies oclusais.

Diferentes estudos como os de RIPA ${ }^{268}$, 1973; RANTALA ${ }^{260}$, 1979; HOROWITZ ${ }^{160}$, 1982; BELL ${ }^{24}$, 1984; DUARTE ${ }^{99}$, 1985; GOMES; TOLEDO ${ }^{135}$, 1992; REGO; ARAÚJO262, 1996, concluíram que os selantes oclusais, em combinação com uso de fluoretos tópicos e sistêmicos, são de grande valor na prevenção de cárie dentária, tanto em nível de Saúde Pública como em clínica particular.

BARBOSA; GARONE FILHO ${ }^{21}, 1974$, aceitaram a ação conjunta do selante com aplicações tópicas de flúor, não colocando impedimento nessa 
aplicação antes ou após a aplicação do selante, mas concordaram com BUONOCORE $^{55}$, 1975, e PAGANI; GIACHETTI ${ }^{246}$, 1978, que essa aplicação tópica não deveria ser realizada após o ataque ácido, pois iria cobrir parcialmente os espaços interprismáticos do esmalte, interferindo na penetração da resina e, consequentemente, na permanência do selante.

TAVARES et al. ${ }^{341}$, em 1987, testaram o grau de permanência de um selante de cicatrículas, fossas e fissuras quando é feito o uso de flúor antes ou depois da aplicação do selante e sem esta associação. Concluíram que o grau de permanência do selante oclusal, após 5 e 10 meses de aplicação, não difere estatisticamente nas 3 condições testadas. Entretanto, há um tendência para melhoria do grau de permanência do selante oclusal quando a aplicação do selante é associada a uma exposição posterior ou quando não há exposição ao flúor tópico, do que uma exposição prévia ao flúor tópico .

Estes dados reforçam a afirmação de NIH CONSENSUS DEVELOPMENT CONFERENCE ${ }^{241}$ que, em 1984, recomenda o uso de flúor tópico após a aplicação do selante. Desta forma, quando a aplicação do selante oclusal for acompanhada de uma aplicação tópica de flúor, TAVARES et al. $^{341}$, 1987, recomendam que esta seja feita posteriormente ao selante oclusal.

Os resultados são semelhantes ao encontrados por SHEYHOLESLAM; HOUPT $^{297}$, 1978, e HOUPT; SHEY ${ }^{165}$, 1983, que obtiveram porcentagens de permanência de $97 \%$ para o mesmo período.

Os resultados aos 10 meses são inferiores aos encontrados por outros autores para o mesmo tipo de selante e num mesmo período de observação. BROOKS et al. ${ }^{44}$, em 1976, 94,6\% em 12 meses, SHEYHOLESLAM; HOUPT $^{297}$, em 1978, 92\% em 11 meses, HOUPT; SHEY ${ }^{165}$, em 1983, 92\% em 11 meses, MCCUNE et al. ${ }^{217}$, em 1979, 91,6\% em 12 meses, MERTZFAIRHURST et al. ${ }^{227} 95 \%$, em 1982, em 12 meses.

DUARTE; ISSAO ${ }^{100}$, em 1987, pesquisaram a técnica de selamento em 40 crianças, na faixa etária de 5 anos e meio e 6 anos e meio. Foram aplicados selantes em 90 primeiros molares permanentes, sendo que em 45 foi também aplicado topicamente fluoreto de sódio acidulado. Verificaram que a permanência dos selantes nos primeiros molares permanentes superiores e inferiores, após 04 meses, de uma única aplicação, apresenta um percentual médio de permanência superior a 90\%. Nos resultados encontrados após 8 meses de acompanhamento verificaram que a permanência dos selantes, no 
Grupo I, com aplicação de flúor é maior que no Grupo II, sem flúor. Nos primeiros molares permanentes superiores a permanência total do selante foi de $95,24 \%$ para o grupo que recebeu também a aplicação tópica de solução fluoretada e, naqueles dentes que receberam somente os selantes, a permanência total foi de $91,67 \%$. Nos molares inferiores esta diferença de permanência aumentou substancialmente, ou seja, permanência de $100 \%$ no Grupo I e 85,71\% no Grupo II. Os resultados de DUARTE; ISSAO'100, em 1987, vêem de encontro aos resultados deste trabalho, onde a associação selante e aplicação tópica de solução fluoretada, além de aumentar o grau de permanência do selante determina uma diminuição de cáries nas superfícies lisas, indicando um boa combinação com um programa de prevenção de cáries dentárias. Em 1982 REISBICK et al. ${ }^{264}$ indicaram o benefício da associação entre o selante e a fluoretação tópica para controle e prevenção da doença cárie.

Como ficou demonstrado na revista da literatura, RIPA ${ }^{268}$ (1973) e RANTALA ${ }^{260}$ (1979), entre outros, se preocuparam em fazer o uso combinado do selante com o flúor, tanto por via sistêmica como por aplicação tópica, pois é sabido que o flúor oferece uma maior proteção para as superfícies lisas e o selante para sulcos, cicatrículas, fissuras e fossas.

KOPEL; GRENOBLE ${ }^{190}$ afirmaram, em 1973, que dentes de indivíduos que sempre utilizaram água fluoretada não deveriam ser bons candidatos à uma boa permanência de selante, o que está em desacordo com os resultados deste trabalho, pois foram observados índices de permanência ótimos para os dentes de ambos os grupos, $\mathbf{A}$ e $\mathbf{B}$, onde os indivíduos dos grupos de estudo eram necessariamente naturais e residentes em Bauru, onde a água de abastecimento público é fluoretada desde outubro de 1975. Ocorreram alguns períodos de interrupção, mas de acordo com o Departamento de Água e Esgoto de Bauru, órgão responsável por esta fluoretação, ela vem acontecendo desde março de 1980 sem nenhuma interrupção. Os pacientes pertencentes aos grupos de estudo foram a indivíduos nascidos no período compreendido entre os anos de 1982 a 1989; supõe-se portanto serem consumidores rotineiros de água de abastecimento público fluoretada.

Trabalho de LEVERETT et al. ${ }^{197}$, em 1983, avaliando selantes por um ano, aplicados em uma população residente em local com água fluoretada 
também encontrou, à semelhança desta pesquisa, ausência de novas lesões cariosas interproximais durante o período de um ano de avaliação, na totalidade dos dentes pertencentes ao grupo de estudo, dados similares aos resultados deste trabalho.

$\mathrm{Na}$ literatura especializada são encontradas referências a fatores que podem interferir na permanência do selante, entre os quais o flúor, o excesso de selante, a contaminação pela saliva, o tipo de sulco, o tipo de dente, a presença ou não de umidade, a idade do paciente, a habilidade do operador, as características de cada selante e a técnica de aplicação. Podem-se citar trabalhos avaliando estes fatores tais como: WILLIAMS; FRAUNHOFER ${ }^{376}$, 1976; DOYLE et al. ${ }^{98}$, 1978; BROOKS et al. ${ }^{45}$, 1979; FERGUSON; RIPA ${ }^{110}$, 1980; LI et al. ${ }^{201}$, 1981; ANDRIONI 9, 1986; STAMM; KATZ ${ }^{321}$, 1993; FORSS; SAARNI; SEPPA ${ }^{116}, 1994$; ZUANON; SANTOS PINTO; CILENEUSE ${ }^{379}$, 1995; DIAS $^{93}$, 1997; JOHNSON; ARMANAZI; SHARP ${ }^{178}, 1997$.

Relativamente ao item "tipo de dente tratado", a unanimidade dos autores demonstra um comportamento superior dos selantes, quanto a permanência e eficácia na prevenção da cárie oclusal, nos pré-molares, quando comparados com os molares permanentes (CUETO; BUONOCORE ${ }^{79}$, 1967; ROCK ${ }^{278}$, 1972; ROCK ${ }^{280}$ 1974; HOROWITZ; HEIFETZ; POULSEN $\left.^{163}, 1977\right)$.

STRANG et al. ${ }^{328}$, em 1986, testaram 3 selantes fotopolimerizáveis e 5 fontes de luz halógena, com potência de $400 \mathrm{~mW} / \mathrm{cm} 2$ em laboratório, para avaliação de tempo e profundidade de polimerização. De acordo com os resultados, os autores aconselharam 60 segundos, como tempo de polimerização ideal para uso na clínica diária, evitando assim, que o selante se solte por polimerização deficiente. Este tempo de polimerização foi 0 adotado no presente trabalho.

SIMONSEN ${ }^{311}$, em 1989, comparou o custo entre aplicação de selante e restauração de lesão cariosa. Concluiu que uma restauração unitária é 1,6 mais cara, quando comparada a uma simples aplicação de selante em crianças que foram acompanhadas por um período de 10 anos, residentes em local com água de abastecimento fluoretada. $O$ pesquisador ressaltou ainda que a combinação entre os métodos preventivos selante e flúor é satisfatória na prevenção de cáries em crianças.

O selante vem evoluindo muito desde o seu desenvolvimento e os benefícios na prevenção da cárie dentária parecem melhorar com a adição de 
flúor à sua composição. O selante fluoretado tem por finalidade atuar não apenas nas cicatrículas, fossas e fissuras, mas também a liberação de flúor para os dentes, de forma a propiciar uma conjunção de procedimentos de reconhecida eficiência na prevenção da cárie.

O selante empregado neste estudo foi o Fluroshield (Caulk/Dentsply, Milford), rotineiramente empregado em clínica e facilmente disponível ao profissional. O selante Fluroshield apresenta uma formulação modificada de BIS-GMA e uretano dimetacrilato diluído. Esta diferença na composição química da matriz monomérica causa diferenças nas suas propriedades, aumentando o escoamento e facilitando o polímero final.

HEROLD ${ }^{156}$, em 1990, afirmou que os selantes com carga são mais efetivos como método preventivo de cárie oclusal e terapêutico de lesões de cicatrículas e fissuras, por apresentarem maior resistência ao desgaste.

PARK et al. ${ }^{248}$, em 1993, opinaram que o monômero uretano pode conferir mais elasticidade e adesividade à resina que o monômero BIS-GMA.

O selante FluroShield (Caulk/Dentsply, Milford) é composto de uma resina fotopolimerizável contendo $50 \%$ de carga inorgânica e $2 \%$ de fluoreto de sódio (em peso), bem como um promotor penta-fosfato. A vantagem do uso deste selante é que algum grau de adesão micromecânica ao esmalte é conseguido e a presença de flúor liberado pode reduzir a possibilidade de cárie secundária, caso o selamento sofra infiltração. O selante então atua como um reservatório, no qual o flúor é gradualmente liberado para a cavidade oral, inibindo a desmineralização do esmalte e participando da sua remineralização.

Alguns autores relataram que a adição e subseqüente liberação de flúor do Fluroshield (Caulk/Dentsply, Milford) não diminui sua retentividade (SUNDFELD et al. $\left.{ }^{333}, 1996\right)$. Entretanto, efeitos a longo prazo do uso deste material são desconhecidos com respeito à estabilidade do agente adesivo $\mathrm{e}$ ao período de liberação dos íons flúor.

Em trabalho de 1993 PARK et al. ${ }^{248}$, utilizando o selante Fluroshield“ e condicionando o esmalte a ser selado com ácido fosfórico a $50 \%$, por 60 segundos, analisaram ao microscópio eletrônico a formação de prolongamentos resinosos na estrutura dental e verificaram que o Fluroshield“ exibiu uniforme e contínua formação de prolongamentos como crivos completos em toda a superfície oclusal onde foi aplicado. 
Em contrapartida, COOLEY et al. ${ }^{77}, 1990$, encontraram microinfiltração em alguns espécimes selados, provavelmente causada pela maior viscosidade deste material, que parece não escoar tão bem dentro das fissuras.

É importante considerar o selante aplicado em um elemento dentário ativo do sistema estomatognático passível de desgaste e abrasão frente ao esforço mastigatório. Sua efetividade não dependerá da fina película que veda a superfície da fissuras, que pode ser facilmente desgastada, e sim do material selador que oblitera um sulco, através de sua penetração em toda extensão da cicatrícula e de sua permanência aumentada em virtude da maior formação de tags (imbricação mecânica superior). Para efetiva imbricação mecânica, os selantes no presente trabalho foram aplicados após condicionamento ácido da superfície de esmalte a ser selada.

$\mathrm{RIPA}^{273}$, em 1993, afirma que uma vez que as superfícies de esmalte sejam tratadas com um agente condicionador ácido e que a resina selante tenha sido aplicada, não é provável ocorrer infiltrações nas interfaces esmalte-selante.

No presente estudo, o condicionamento ácido do esmalte, prévio ao selamento, foi realizado utilizando-se o ácido fornecido pelo fabricante (ácido fosfórico gel a 50\%), aplicado com um pincel durante 60 segundos, como preconizado por MOORE; JACKSON ${ }^{235}$, em 1988. De acordo com GWINNETT; BUONOCORE ${ }^{146}$, em 1972, a concentração ideal para um condicionamento eficiente com ácido fosfórico está entre 30 a 50\%, pois concentrações menores provocam menor ataque.

GWINNET ${ }^{143}$, em 1973, destacou o aumento da área de superfície e o aumento e intensificação dos microporos do esmalte como sendo muito importantes. Mencionou que a solução ácida, ao remover a camada externa do esmalte, expõe uma camada mais interna potencialmente reativa, apresentando melhor energia de superfície e ampliando dessa forma a capacidade de "molhamento" do selante em relação ao esmalte. Ainda em 1973, RETIEF ${ }^{265}$ concluiu com seu estudo, que, com ácido fosfórico a 50\% ocorrerá um íntimo contato interfacial entre o selante e o tecido dental.

Em relação à profilaxia prévia ao condicionamento ácido os trabalhos na literatura apresentam resultados controversos.

Autores como DENNISON et al. ${ }^{91}$, em 1974, consideraram a limpeza superficial, precedendo o selamento, dispensável. Por sua vez, STRAND; 
RAADAL ${ }^{326}$, em 1988, afirmaram ser importante remover o material orgânico antes do selamento e alcançaram ótimos resultados de penetração do selante em estudos com profilaxia dental utilizando instrumento com jato de ar associado a água e partículas de bicarbonato de sódio com $45 \mathrm{~mm}$. Já ANDRIONI $^{\circ}$, em 1986, alcançou melhores resultados com profilaxia prévia apenas com pedra pomes e água aplicados com escova Robson em baixa rotação, enquanto DONNAN; BALL ${ }^{97}$, em 1988, não encontraram diferenças estatisticamente significantes para a permanência de selantes aplicados após profilaxia com pedra pomes e escova Robson em baixa rotação, ou para aqueles aplicados sem nenhuma profilaxia, antes do condicionamento ácido das superfícies de esmalte.

REGO; ARAÚJO ${ }^{262}$, em 1996, relataram $100 \%$ de permanência para o selante FluroShield, aplicado após profilaxia prévia ao condicionamento ácido com escova Robson em baixa rotação e água oxigenada a $3 \%$, controle de 6,12 e 18 meses.

A possibilidade de selamento de fissuras sem profilaxia prévia pode ser considerada, desde que o dente esteja livre de deposições grosseiras de placa ou cálculo; isto acarretaria uma economia de tempo clínico e simplificação da técnica operatória, para autores como ROCK ${ }^{280}, 1974$; GARCIA-GODOY; GWINNETT ${ }^{123}$, 1987; BOGERT; GARCIA-GODOY ${ }^{28}$, 1992; WAGGONER; SIEGAL ${ }^{364}, 1996$; DIAS ${ }^{923}$ 1997; SUNDFELD ${ }^{334}, 1998$.

GILLCRIST et al. ${ }^{129}$, em 1998, não encontraram diferenças estatisticamente significantes entre a porcentagem de permanência de selantes aplicados com profilaxia prévia com pasta profilática em baixa rotação e apenas escovação das superfícies com escova dental e água.

Em 1999 SOUZA; PITTA ${ }^{316}$ disseram não encontrar diferenças estatisticamente significantes entre a porcentagem de permanência de selantes em 3 grupos distintos submetidos a profilaxia prévia com pedra pomes, com jato de bicarbonato (Profident) ou sem profilaxia. Todos os grupos foram avaliados após 6 e 12 meses para testar a integridade do selante. Os resultados mostraram que o grupo sem profilaxia apresentou aos 12 meses um porcentual de permanência (92,9\%) levemente inferior aos outros dois grupos experimentais, os quais tiveram $94,3 \%$ de permanência total após um ano.

No presente trabalho, a profilaxia prévia ao condicionamento ácido das superfícies de esmalte foi realizada com água oxigenada a $3 \%$ aplicada com 
movimentos circulares com escova Robson em baixa rotação. Os resultados de permanência dos selantes encontrados após 6 e 12 meses podem ser comparados aos do trabalho de REGO; ARAÚJJO ${ }^{262}$ de 1996. O fato de todos os selamentos serem realizados com uso do isolamento absoluto possivelmente teve influência nos resultados obtidos.

Apesar de EIDELMAN; FUCKS; CHOSAK ${ }^{103}$, 1983; STRAFFON et al ${ }^{325}$, 1985, não terem encontrado em trabalhos por eles realizados diferenças estatisticamente significantes na permanência de selantes aplicados com isolamento absoluto e relativo, vários outros trabalhos mostraram ser essencial a utilização de isolamento absoluto para maior efetividade dos selantes. Podem-se citar com esta filosofia trabalhos de SILVERSTONE ${ }^{304}$, 1983; VERTUAN; BARELLI; SERRA ${ }^{358}$, 1988; RIPA ${ }^{272}$, 1993; LIEBENBERG ${ }^{200}$, 1994; TIBANA ${ }^{346}$, 1994; LYGIDAKIS; OULIS; CHRISTODOUL ${ }^{209}$, 1994; JOHNSON; ARMANAZI; SHARP'178, 1997.

CHIBINSKI; CZLUSNIAK ${ }^{73}$, em 1996, afirmaram que a longevidade de um selante, no que diz respeito à permanência, depende única e exclusivamente de sua capacidade adesiva e das condições do aderente. $O$ selante precisa apresentar condições físico-químicas adequadas para ter adesividade e o aderente (esmalte dental) deve ser tratado de modo a fornecer condições básicas de adesão ao selante (topografia de superfície, baixa energia de superfície).

Para MENAKER ${ }^{224}$, em 1984, depois que o selante polimerizou-se integralmente a superfície deverá ser inspecionada; o exame deverá ser feito com uma sonda exploradora afiada. A ponta deverá correr levemente sobre a superfície do dente. A presença ou ausência de selante, em uma dada área, poderá ser detectada pelo tato. O selante provoca uma sensação mais lisa e macia do que o esmalte (os selantes com carga são mais ásperos do que o esmalte). Bolhas de ar que tenham sido incorporadas na superfície mostrarse-ão como irregularidades e poderão ser identificadas visualmente. Um selante aplicado de maneira apropriada não deverá ter bolhas de ar, deverá preencher as cicatrículas, fissuras e fossas oclusais e se estenderá pelos sulcos rasos da periferia da superfície oclusal. Se a cobertura das cicatrículas ou fissuras não for integral ou bolhas de ar estiverem presentes, a área em questão deverá ter as bolhas removidas e ser novamente tratada e aplicado o selante. Estas considerações foram seguidas no presente trabalho, onde 
todos os selamentos foram avaliados imediatamente após a polimerização e, se encontradas falhas na aplicação esta foi refeita, sendo o isolamento absoluto removido apenas quando o selamento estivesse em perfeitas condições. Este deve ter sido um dos fatores principais que contribuiu para os resultados de permanência alcançados após 6 e 12 meses.

MENAKER $^{224}$ salienta ainda que também a oclusão deverá ser examinada, em especial se for empregado um selante com carga, como foi o caso do selante utilizado no presente trabalho. Com este tipo de selante, qualquer interferência na oclusão deverá ser eliminada pela técnicas convencionais de acabamento de compósitos. Exceto no caso de ligeira interferência de oclusão, os selantes em fase inorgânica (sem carga) não requerem ajuste mecânico, uma vez que se desgastam naturalmente quando em contato com a cúspide do dente oponente. No entanto, se a interferência oclusal for severa ou grosseira, pode ocorrer a fratura do selante. Tais interferências poderão ser corrigidas mecanicamente. Chama a atenção que interferências grosseiras com a oclusão resultam de técnica de inserção mal conduzida, que deverá, portanto, ser evitada.

Por outro lado, CHIBINSKI; CZLUSNIAK ${ }^{73}$, em 1996, também disseram que deve-se esperar uma maior resistência ao desgaste por parte dos selantes com carga, daí a necessidade do ajuste por desgaste mecânico.

Outro aspecto que deve ser considerado é que se realizou exame da oclusão, e ajustes necessários, após todas as aplicações de selante, para não deixar contatos oclusais exagerados ou prematuros e desconforto aos pacientes, o que foi sugerido por TILLIS et al. ${ }^{347}$, em 1992, quando afirmaram que o desgaste natural de selantes resinosos com carga não é suficiente para restabelecer contatos oclusais confortáveis aos pacientes se estiverem em excesso, o que foi reforçado também em 1992, por STACH et al. ${ }^{317}$. Deve-se esperar uma maior resistência ao desgaste por parte dos selantes com carga. É inerente a este tipo de material a formação de uma película mais espessa, o que obriga o ajuste oclusal após sua aplicação.

A associação da aplicação tópica de fluoreto acidulado com o selante aumenta o grau de permanência deste último, estando de acordo com os resultados obtidos por DUARTE ${ }^{99}$, em 1985. Esta associação é um meio de prevenção eficaz, pois, além de aumentar o grau de permanência do selante, determina uma diminuição na incidência de cáries proximais. Os resultados 
do presente trabalho são similares aos de DUARTE; ISSAO ${ }^{100}$, em 1987, e os de VALSECKI; VERTUAN ${ }^{353}$, em 1988.

A permanência e eficácia do selante foram testados por período de 24 meses por VALSECKI; VERTUAN ${ }^{353}$, em 1988, em primeiros molares permanentes de 132 crianças de 6 a 7 anos de idade que receberam medidas preventivas com:

a) selante oclusal autopolimerizável exclusivamente e

b) selante associado com flúor fosfato acidulado 1,23\%.

O selante apresentou excelentes índices de permanência e eficácia e sua associação com o flúor tópico permitiu que estes índices fossem superiores a sua aplicação isolada. Observa-se que os porcentuais de permanência completa foram maiores para o grupo de associação de medidas (Selante+Flúor), a partir do $12^{\circ}$ mês, em relação ao grupo Selante.

Quanto às perdas dos selamentos, os porcentuais verificados indicam que os maiores índices destas perdas se localizam nos primeiros 6 meses após a aplicação dos selantes, semelhantes ao encontrado por BAGRAMIAN et al. ${ }^{19}$, em 1979.

Os maiores índices de perdas, no estudo de VALSECKI; VERTUAN ${ }^{353}$, em 1988, para os 6 primeiros meses de observação, estiveram provavelmente relacionados às deficiências de isolamento e condicionamento ácido, como salientado por BAGRAMIAN et al. ${ }^{19}$, em 1979; BASSO ${ }^{20}$, em 1983; ISSAO; ANDO ${ }^{172}$, em 1983 e MOORE; JACKSON ${ }^{235}$, em 1988.

Verificou-se, no trabalho de VALSECKI; VERTUAN ${ }^{353}$, 1988, que a incidência de cáries e/ou restaurações, tanto para as superfícies lisas quanto para as oclusais, é bem inferior para o grupo com associação de medidas preventivas (Selante+Flúor), seguido pelos grupo Selante, em todos os períodos de reexame.

As diferenças na ocorrência de cárie e/ou restaurações e sua eficácia entre os grupos estudados foram estatisticamente significantes a nível de $5 \%$ e $1 \%$ respectivamente, após 24 meses.

Dentre os fatores responsáveis pela diferença dos resultados obtidos entre os grupos Selante+Flúor e Selante, principalmente para as faces lisas, está a efetivação do íon flúor. Além disso, o flúor estaria também conferindo resistência às regiões que margeiam 0 selante, eventualmente desprotegidas.

À vista dos resultados, pode ser atribuído ao flúor uma ação indireta sobre a manutenção dos selamentos oclusais por contribuir efetivamente na 
manutenção da integridade das faces lisas e assim, dispensar a realização de restaurações com extensão para a oclusal.

Os resultados do trabalho de VALSECKI; VERTUAN ${ }^{353}$, em 1988, para ambos os grupos, foram crescentes com o tempo, porém, sempre maiores para o grupo que recebeu a associação do selante e o flúor (Selante+Flúor), apontando o efeito positivo do íon flúor associado aos benefícios do selante. Estes resultados podem ser comparados positivamente com os resultados obtidos no presente trabalho.

BERNARDES et al. ${ }^{25}$, em 1994, realizaram trabalho com o objetivo de avaliar a efetividade do selante FluroShield“, através de uma pesquisa com este material, aplicado em 90 dentes de 18 crianças com idade entre 6 e 12 anos. O selante foi aplicado em esmalte condicionado com ácido fosfórico a $50 \%$ por 60 segundos e teve sua fotopolimerização realizada com exposição a luz durante 20 segundos. Na avaliação realizada 6 meses após, os índices de permanência encontrados foram: $82,2 \%$ de permanência total, 15,6\% de permanência parcial e 2,2\% de perda total. Na avaliação de 1 ano os índices foram: $80,0 \%$ de permanência total, 17,8\% de permanência parcial e 2,2 de perda total. Em relação à prevenção de cárie, apenas um dente se apresentou cariado aos 6 meses, o que significa 98,9\% e, depois de 1 ano, mais um dente se apresentou cariado, representando 97,8\% de prevenção. Em função disso, concluiram:

1- o selante é seguro e de fácil aplicação, desde que a técnica seja rigorosamente seguida;

2- o Cirurgião-Dentista deve incentivar os pacientes e seus responsáveis a se sujeitarem à aplicação do selante. Não existem mais razões para os Cirurgiões-Dentistas continuarem com receio de selar, criteriosamente, lesões de cáries incipientes;

3- o selante FluoroShield“ apresentou-se efetivo, com $80,0 \%$ de permanência total, depois de 1 ano. O flúor, presente em sua composição, não foi avaliado quanto à sua influência na retentividade e na prevenção de cárie;

4- a aplicação do selante deve ser realizada como parte de uma filosofia preventiva, associada a aplicações periódicas de flúor, instruções sobre higiene oral e controle da dieta, além das consultas de revisão.

SUNDFELD et al. ${ }^{332}$, em 1994, afirmaram ser o selamento de cicatrículas, fossas e fissuras uma técnica reconhecidamente eficaz na prevenção da cárie 
dental oclusal. De fato, os seus resultados revelaram o excelente comportamento clínico e microscópio apresentado pelo selante Fluroshield, quanto à permanência e penetração no esmalte dental, respectivamente. Os autores encontraram "in vivo" após 6 meses o referido selante com taxa de permanência de $92 \%$ na superfície oclusal. A análise microscópica dos cortes por desgaste demonstrou uma boa adaptação do selante ao esmalte dental condicionado em 27 espécimes, enquanto em cinco foi observada falha de adaptação (fenda) na interface selante/esmalte, fato também evidenciado por COOLEY et al. ${ }^{77}$, em 1990, quando da análise desse material em microscopia eletrônica de varredura. Alegaram, entretanto, que a presença dessas fendas pode não ser clinicamente significante, se considerada a habilidade desse selante em doar flúor ao esmalte dental.

Empregando uma solução corante na superfície oclusal de pré-molares que tiveram suas fossas e fissuras seladas, SUNDFELD ${ }^{329}$, em 1990, verificou, através da análise clínica fotográfica, o aparecimento ou até mesmo o desaparecimento de bolhas na superfície dos selantes analisados, demonstrando com isso a ocorrência de um desgaste ao longo do tempo. Esse fato também foi verificado com o selante Fluroshield“, uma vez que os 15 espécimes que receberam a aplicação da solução corante apresentaram bolhas superficiais aos 6 meses de análise clínica. Em função disso afirmaram que, com o desgaste superficial apresentado por esse selante ao longo do tempo, ocorre a exposição de novas superfícies do material resinoso ao meio oral, o que possibilitará, provavelmente, a liberação de flúor contido na massa do selante.

O fato de o selante Fluroshield“ apresentar uma grande viscosidade possibilitou sua aplicação no interior do sulco, com auxílio de uma sonda exploradora, o que de certa forma colaborou com sua adequada e uniforme penetração no esmalte dental condicionado, uma vez que o selante foi aplicado no interior do sulco sob vibração e pressão, executadas de encontro aos planos inclinados cuspídeos.

Além dos fatores acima relacionados, o selante Fluroshield" foi polimerizado 10 segundos após sua aplicação no interior do sulco, o que pode ter contribuído para seu escoamento e satisfatória penetração no esmalte dental condicionado, mesmo apresentando 50\% de partículas de cargas inorgânicas em sua composição, por peso. 
Reafirmando essas ponderações, CHOSACK; EILDELMAN ${ }^{74}$, em 1988, alegaram que não é conveniente iniciar a polimerização de um selante imediatamente após sua aplicação, o que impediria sua adequada penetração nos microporos do esmalte dental condicionado, fato esse de extrema relevância para a obtenção de uma permanência mecânica satisfatória.

Os dados obtidos por SUNDFELD et al. ${ }^{330}, 1990$, na análise microscópica corroboram os registrados clinicamente, nos quais o selante Fluroshield" apresentou uma excelente taxa de permanência total na superfície oclusal, ou seja, 96,2\%, após 6 meses de análise.

SUNDFELD et al. ${ }^{333}$, em 1996, verificaram uma excelente taxa de permanência do material na superfície dental 12 e 18 meses após sua aplicação, respectivamente, ressaltando ainda que a adição e subseqüente liberação de flúor pareceu não afetar a permanência do material ao longo do tempo.

Esse achado clínico vem, sem dúvida alguma, confirmar a eficácia da técnica adotada e empregada durante o selamento oclusal

SUNDFELD et al..$^{333}$, em 1996, ressaltaram que a excelente taxa de permanência total apresentada por esse selante pode também estar aliada ao fato de ter-se polimerizado o material 10 segundos após sua aplicação no interior com sua satisfatória penetração no esmalte dental condicionado, mesmo apresentando $50 \%$ de partículas de carga inorgânica em sua composição por peso.

REGO; SILVA; ARAÚJO263, em 1998, dizendo que aproximadamente metade das lesões de cáries em crianças e a maioria aos 15 anos de idade são lesões de cáries oclusais sendo este número reduzido com a aplicação de selantes, avalia clinicamente a eficiência e durabilidade de um selante com carga e flúor (Fluroshield“) em dentes submetidos à ameloplastia e de um selante sem carga e flúor (Delton") aplicado sem uso da técnica invasiva. Foram aplicados selantes fotoativados em 162 dentes (pré-molares e molares de 39 pacientes), os quais foram avaliados após 6,12,18 e 24 meses. Nos controles realizados após 6 e 12 meses os valores de permanência foram de 100 por cento, aos 18 meses de 93,75 por cento, enquanto aos 24 meses de 92,30 por cento, não ocorrendo a presença de cárie oclusal em todas as avaliações. Não ocorreram diferenças significativas no comportamento clínico entre o Fluroshield“ e o Delton“, nem também entre os selantes nas 
arcadas superior e inferior. Ambos selantes apresentaram permanência satisfatória após 24 meses de aplicação, com 1,92 por cento de perda total para o Fluroshield“ e 1,42 por cento para o Delton“.

Para PALMA et al..$^{247}$, em 1994, a resina fluoretada tem a vantagem sobre o cimento de ionômero de vidro de produzir uma película mais fina e uma superfície mais lisa do selante e, também, uma melhor permanência ao dente, devido ao fato de ser um composto mais fluido que o ionômero, permitindo melhor imbricação mecânica, mas com a desvantagem de liberar menos flúor pelo seu fator resinoso.

$\mathrm{Na}$ avaliação clínica de VILLELA et al ${ }^{360}, 1998$, realizada após 24 meses da aplicação dos materiais Fluroshield" e Vitremer" por um avaliador através de exame táctil-visual, utilizando sonda exploradora, espelho clínico e luz artificial, sob isolamento relativo cada dente foi classificado segundo os critérios propostos por TONN; RYGE ${ }^{348}$ (1982). Após vinte e quatro meses, os dentes foram avaliados e classificados. Os resultados na avaliação aos doze meses obtiveram $100 \%$ de permanência total para o Fluroshield“, sendo que Vitremer" apresentou permanência total em 82,60\% dos casos; perda em $13,04 \%$, perda total em 4,35\%. O condicionamento ácido do esmalte previamente à aplicação do material ionômero de vidro modificado por resina pode ter contribuído, possibilitando a penetração de projeções do cimento "tags" nas microporosidades formadas na superfície do esmalte dental, como descrito por SUNDFELD et al. ${ }^{332}$, em 1994 e por PERCINOTO et al. ${ }^{249}$, em 1995.

SILVA; REGO; ARAÚJO ${ }^{300}$, em 1996, avaliaram clinicamente a eficiência e durabilidade de selamento com um selante com carga e flúor (Fluroshield), e com cimento ionômero de vidro (Variglas). Não ocorreram diferenças significativas no comportamento clínico entre o Fluroshield e o Variglas. Ambos selantes apresentaram permanência satisfatória após 12 meses da aplicação, com 96,72 por cento de permanência total para o Fluroshield e 93,55 por cento para o Variglas.

VONO; VONO; FIGUEIREDO ${ }^{361}$, em 1996, comparando selantes com carga e com flúor (Fluroshield") e ionômero de vidro (Variglas“ VLC), verificaram que o selante Fluroshield" teve um comportamento clínico superior ao do Variglas", com diferenças estatisticamente significantes.

Em um estudo clínico de um ano de acompanhamento, WINKLER et al. ${ }^{377}$ em 1996, observaram que um cimento de ionômero de vidro 
modificado por resina (Fuji“ II LC-GC) apresentou um desgaste acentuado, além de uma taxa de permanência menor do que um selante à base de BISGMA (Concise-3M). No entanto, não houve diferença significante quanto ao desenvolvimento de lesões de cárie ou descoloração marginal.

$\mathrm{Na}$ análise do tempo gasto nas aplicações dos selantes FORSS; SAARNI; SEPPA ${ }^{116}$ (1994) demonstraram que os dentistas precisam de mais tempo para aplicar os selantes de ionômero de vidro que o resinoso. Quando o tempo gasto nas reaplicações é também considerável (60\% mais tempo nos selantes de ionômero de vidro), os resultados de FORSS; SAARNI; SEPPA ${ }^{116}$ (1994) sugerem que o uso do ionômero de vidro como material selador pode não ser prático quando comparado com as aplicações de selantes resinosos. Desde que o preço dos selantes de ionômero de vidro e os resinosos são equivalentes, até o momento no estudo de FORSS; SAARNI; SEPPA ${ }^{116}$, a aplicação de selantes de ionômero de vidro foi mais cara que a dos resinosos. Por outro lado, os dentistas responsáveis pelo trabalho clínico do estudo eram previamente mais experientes em manusear o material selante resinoso ao ionômero de vidro, o que pode ter afetado o resultado.

Em 1990, OVREBO; RAADAL ${ }^{245}$ avaliaram a microinfiltração em fissuras seladas com selante resinoso e com cimento ionomérico. No selamento com material resinoso verificaram melhores resultados pois não encontraram microinfiltração em $93 \%$ dos dentes selados e, em 7\% encontraram apenas infiltração superficial.

Para avaliar a permanência de um tipo de selante auto-polimerizável (Delton“ da Johnson \& Johnson) em superfícies oclusais de pré-molares e 1ํㅡㄴ molares permanentes os autores DIN; VERTUAN; MENDES ${ }^{94}$, em 1989, utilizaram escolares de $1^{\circ}$ grau, com idade de 6 a 9 anos, em Araraquara, São Paulo.

Para superfícies de 1 molares permanentes foi observada completa permanência de 92,8\% e 87,0\%, respectivamente após 6 e 12 meses, apresentando-se esta permanência com diferença pouco significante entre $1^{\circ}$ molares superiores em relação com os inferiores, justificando-se assim a escolha dos molares inferiores para posterior selamento, possibilitando maior visibilidade do campo operatório, além do que a sua anatomia está mais predisposta ao aparecimento da lesão cariosa em relação aos pré-molares. 
O grau de permanência do selante Delton" em molares decíduos e permanentes em crianças de 2 a 8 anos de idade durante 18 meses foi verificado, em 1990, por PRADO; GARONE NETTO ${ }^{256}$, onde encontraram o maior número de perdas do selante, ocorreu na fossa disto molar dos primeiros molares permanentes superiores. Onde os dentes se mantiveram total ou parcialmente selados, não apresentaram cárie durante o referido período, concluindo ser válido na prevenção de cáries oclusais em dentes decíduos em crianças nessa faixa etária.

OHKUBO et al. ${ }^{243}$, em 1982, em controle de 12 meses após aplicação de selante Delton" verificaram $92 \%$ de permanência total.

PRADO; GARONE NETTO ${ }^{256}$, em 1990, em controle de 12 meses após aplicação de selante Delton“ verificaram $97 \%$ de permanência total.

STRAFFON ${ }^{324}$, em trabalho de 1988, mostrou que através da aplicação adequada de selantes e controles com intervalos de 6 meses consegue-se manutenção adequada destes selantes por um período de 7 anos. Publicou um trabalho onde, para manter o selante intato, foi necessário retratamento em aproximadamente $20 \%$ após 6 meses, conseguindo manter $50 \%$ das superfícies seladas sem necessidade de reaplicação por um período de 7 anos. Nesse mesmo período, dos 50\% restantes, 30\% necessitaram de apenas uma reaplicação.

No que diz respeito à permanência total dos selantes, os resultados são próximos aos de GOING et al. ${ }^{133}$ (1976), de CHARBENEAU; DENNISON; $\mathrm{RYGE}^{72}$ (1977) que, após de 6 meses, encontraram uma permanência de $80,4 \%$ e $90,6 \%$, respectivamente e aos de RICHARDSON; GIBSON; WALDAN $^{267}$, (1980) que, após 12 meses, encontraram uma permanência total de $91,6 \%$ e $89,6 \%$, respectivamente.

MEJARE; MJOR ${ }^{223}$, em 1990, acompanharam 208 dentes molares e prémolares permanentes por um período de 6 meses a 5 anos. Verificaram que os selantes resinosos apresentaram permanência completa em $90 \%$ dos casos.

$\mathrm{ROCK}^{279}$, em 1973, apresentou os resultados obtidos, após 6 e 12 meses, de uma única aplicação dos selantes Nuva Seal“ e Epoxylite“ 9075, aplicados em crianças entre 12 e 13 anos. Todos os dentes que foram selados com o Nuva Seal“ mostraram-se íntegros, ao final dos períodos de observação.

Considerando-se a permanência como a principal característica a ser avaliada na efetividade dos selantes, $100 \%$ de permanência total, neste 
estudo, nos dois grupos aos 6 meses e $100 \%$ no grupo A e $67 \%$ no grupo B aos 12 meses demonstraram adequado comportamento clínico.

No que diz respeito à eficácia na prevenção da cárie e na combinação dos dois métodos (selante + aplicação tópica), os resultados mostram dados interessantes e animadores.

Pode-se verificar que, após 12 meses de experimentação, o porcentual de cáries na superfície oclusal foi de 0,00\%, mostrando a eficácia dos selantes como meio de prevenção de cáries oclusais, mesmo em casos de uma perda parcial do selante. Estes resultados estão de acordo com os relatados por REGO; ARAÚJO ${ }^{262}$, em 1996, que, após selamento com Fluroshield onde aplicaram flúor gel antes da remoção do isolamento absoluto, avaliando esses selantes após 6 e 12 meses encontraram 100\% de permanência e nenhuma nova lesão cariosa presente em todos os dentes estudados. Para KOPEL ${ }^{189}$, em 1971, além do ataque ácido propiciar um aumento na aquisição de flúor pelo esmalte, a aplicação tópica de flúor a uma superfície de esmalte atacada por ácido favoreceria a remineralização do esmalte, o que pode explicar a maior resistência à formação de novas lesões cariosas.

Quanto às cáries de superfícies lisas, os resultados mostraram que, nos primeiros molares permanentes onde foi efetuada a aplicação tópica, associada com o selante, o número de superfícies cariadas é idêntico, quando em confronto com aquelas nas quais foi feito apenas o selante, ou seja, nenhuma lesão clinicamente diagnosticável presente; o que deve ser decorrente da associação do flúor liberado nas horas inicias após aplicação do selante, do flúor presente na água de abastecimento público e no dentifrício de uso diário assim como da aplicação, pelo componentes do grupo de estudo, das orientações dadas logo após a aplicação do selante sobre a doença cárie dental e os fatores envolvidos em seu desenvolvimento (microbiota, dieta e hospedeiro). Deve-se ainda relembrar que por se tratarem de indivíduos pertencentes a um grupo de estudo envolvendo exame periódico intra-bucal tal fator deve ser estimulador de auto-cuidado da saúde bucal.

Estes achados nada mais são do que a confirmação da proposição de BUONOCORE $^{53}$ (1970), o qual dela relata o fluoreto como um selamento que oferece uma maior proteção à superfície lisa. Daí a importância do seu uso combinado com o do selante. 
BERNARDES et al. ${ }^{24}$, em 1994, discorrendo a respeito da ocorrência de cáries na superfícies dentais oclusais disseram que os sulcos, cicatrículas e fissuras da superfície oclusal dos dentes apresentam uma anatomia caracterizada por "falhas" profundas, estreitas e sinuosas, que impossibilitam uma higienização perfeita e, conseqüentemente, facilitam o acúmulo de bactérias e restos alimentares.

Segundo MENAKER ${ }^{224}$, em 1984, e BJARNASON ${ }^{26}$, em 1998, a fluoretação reduz significativamente o índice de cárie em superfícies lisas, mas propícia apenas uma redução discreta na incidência de cáries oclusais que são responsáveis por $50 \%$ de todas as cáries. Esse índice é um alerta para a necessidade de algum método de prevenção de cárie de sulcos, fossas, cicatrículas e fissuras, de acordo com BRUNELLE; CARLOS ${ }^{49}$, em 1990.

Os selantes oclusais continuam sendo importantes e eficazes materiais que o Cirurgião-Dentista poderá fazer uso na prevenção de lesões de cárie de cicatrículas e fissuras e esta afirmação é coerente com as de STAMM $^{318}$, em 1983; HOROWITZ ${ }^{160}$, em 1982 e BOHANNAN ${ }^{29}$, em 1982.

FRANCO; MAGRO; CARVALHO ${ }^{119}$, em 1994 dizem que aplicação de selantes na região de cicatrículas e fissuras, associada a outras técnicas preventivas, é de grande importância na proteção contra cáries nessas regiões. Para avaliar a permanência deste material, por períodos variáveis de tempo, foram examinados 84 pacientes que haviam se submetido ao selamento, num total de 345 superfícies oclusais seladas, no período de 1983 a 1990. Realizaram exame clínico pela aplicação de fucsina básica na superfície envolvida e, em alguns casos, sondagem. Observaram uma porcentagem de presença total de 71,30 por cento. Nos restantes 28,20 por cento foi observado presença parcial ou substituições por restaurações, recidiva de cárie e ausência de selante, assim como extração por finalidade ortodôntica. O selante mostrou-se efetivo na prevenção de lesões de cáries de cicatrículas e fissuras.

A pesquisa por materiais dentários com propriedades de liberar fluoreto e assim por si só serem capazes de interferir com o desenvolvimento da cárie foi intensa na última década. Entre os trabalhos observa-se o de CURY; $S_{A A D}{ }^{33}$, em 1993, com o objetivo de estudar o comportamento do selante FluroShield em liberar flúor quando imerso em água deionizada, saliva artificial e ciclagens e pH (soluções Desmineralizante 
e Remineralizante). Conclui-se que a liberação de flúor foi diferente nos meios estudados, sendo observadas concentrações cariostáticas significativas para este selante.

HICKS; FLAITZ ${ }^{157}$, em 1992 afirmaram que sem dúvida o selante fluoretado irá liberar flúor e alcançar uma proteção adicional à formação de cárie secundária nas superfícies dentais próximas; conceito este que já havia sido dito por ROBERTS et al. ${ }^{276}$, em 1984. Disseram ainda, que o condicionamento ácido do esmalte, realizado previamente à aplicação do selante, tornará esse esmalte mais reativo para a absorção de flúor, em relação ao esmalte intacto, fato também relatado por AASENDEN; BRUDEVOLD; MCCANN', em 1968, e RAWLS ${ }^{261}$, em 1991.

A maior reatividade do esmalte condicionado para a absorção de flúor pode ter relação com a maior permanência do selante nos dentes do grupo $A$, onde se realizou a aplicação tópica de flúor imediatamente após findo o selamento, antes da remoção do isolamento absoluto; grupo esse que alcançou $100 \%$ de permanência de selante no período avaliado de 12 meses.

Considerando como certos os comentários de CARVALHO et al. ${ }^{65}$, em 1990, de que o conteúdo de flúor nos dentes e sua relação com a experiência de cárie dos indivíduos são controversos na literatura e que vários autores falharam em demonstrar tal relação, pois o desenvolvimento da cárie depende de vários fatores difíceis de ser controlados, tais como dieta, higiene oral, suplementação de flúor etc. e não somente do conteúdo de flúor no dente, para TERADA et al. ${ }^{343}$, em 1998, torna-se impossível definir a quantia mínima de flúor que seria necessária para se obter uma máxima proteção contra as cáries.

TERADA et al. ${ }^{343}$, em 1998, realizaram trabalho que teve como objetivo verificar em laboratório a liberação de flúor. Foram testados quatro cimentos de ionômero de vidro convencionais, uma resina composta e um selante de cicatrículas e fissuras. A avaliação foi feita em três períodos: 24 horas, 7 dias e 28 dias. Todos os materiais testados liberaram quantidades significantes de flúor na forma em que foi conduzido o experimento. Observa-se que existe uma liberação inicial acentuada nas primeiras horas chamada "efeito explosão". Em seguida, para todos os materiais, verifica-se uma queda brusca nas taxa de liberação entre o primeiro e o segundo intervalo.

Trabalhos na literatura mostram resultados satisfatórios com a utilização do selante Fluroshield, tanto em relação à sua permanência, como ao seu 
papel liberador de flúor e também no controle do aparecimento de novas lesões cariosas, entre eles os de COOLEY et al. ${ }^{77}$, 1990; JENSEN et al. ${ }^{176}, 1990$; SUNDFELD et al. ${ }^{330}$, 1991; BERNARDES et al. ${ }^{25}$, 1994; SUNDFELD et al. ${ }^{332}$, 1994; CAMLOFFSKI; MAZUREK ${ }^{57}$, 1996; OKIDA; MANDARINO; CURY ${ }^{244}, 1997$.

TANAKA et al. ${ }^{340}$, em 1987, afirmaram que o flúor liberado do selante será depositado em significantes concentrações de até $60 \mu \mathrm{m}$ de profundidade no esmalte; concluíram que selantes resinosos fluoretados podem proteger 0 esmalte de lesões cariosas mesmo após queda desse selante.

TURPIN-MAIR; RAWLS ${ }^{351}$, em 1992, realizaram trabalho comparando permanência de 2 selantes resinosos, um que libera flúor e outro não. $O$ selante que libera flúor apresentou maior índice permanência que o selante que não o libera, em 12 meses respectivamente $74 \%$ e $68 \%$ de permanência total. O selante com flúor mostrou melhor permanência e potencial para maior efeito na prevenção de cáries.

OKIDA; MANDARINO; CURY244, em 1997, opinaram que a literatura tem demonstrado que os materiais odontológicos que liberam flúor são determinantes para controlar o desenvolvimento de cáries, uma vez que o flúor proveniente destes materiais pode ser incorporado ao esmalte dental. DONLY et al. ${ }^{96}$, em 1999, avaliando o papel de vários materiais restauradores com adição de flúor na inibição da desmineralização e no auxílio à remineralização de lesões cariosas incipientes, afirmaram que o flúor liberado por estes materiais é efetivo para a proteção das superfícies dentais adjacentes a área em que foram utilizados.

Em virtude disto, GRON ${ }^{141}, 1977$; SILVERSTONE ${ }^{302}$, 1977; SILVERSTONE et al. ${ }^{305}$, 1988; CURY ${ }^{81}$, 1989; TEN CATE ${ }^{342}$, 1990; CURY ${ }^{82}$, 1992, descreveram o papel do flúor na cavidade oral no processo de DES/RE do esmalte dental, demonstrando que a utilização diária de produtos que contenham flúor em sua composição, em pequenas concentrações, é suficiente para a promoção de deposição de minerais e inibição de sua dissolução.

Essas observações foram confirmadas no trabalho de OKIDA; MANDARINO; CURY ${ }^{244}$, em 1997, quando verificaram os resultados do selante FluroShield“ e do Vitrebond“. No FluroShield“, foi possível constatar uma pequena capacidade em liberar flúor. 
Acompanhando esse pensamento pode-se considerar que o selante Fluroshield" utilizado na presente investigação deve ter sido um dos fatores determinantes para a prevenção de lesões cariosas nos dentes dos grupos de estudo.

Em 1990, COOLEY et al. ${ }^{77}$, quando da análise do Fluroshield“ em microscopia eletrônica de varredura, observaram falha de adaptação na interface selante/esmalte, fato também evidenciado por SUNDFELD et al. ${ }^{331}$, em 1992, através da microscopia óptica comum, sob luz polarizada. Alegaram, entretanto, que a presença dessas fendas pode não ser clinicamente significante, se considerada a habilidade desse selante em doar flúor ao esmalte dental. Acompanharam a liberação de flúor do referido selante durante 7 dias; observaram efeito de explosão de liberação de flúor nos 2 primeiros dias. Desse dia em diante diminui a liberação de flúor até aproximadamente a metade até o sétimo dia. Afirmaram ainda que a habilidade de liberar flúor irá proteger o esmalte até $60 \mu \mathrm{m}$ de profundidade.

Por outro lado, o flúor liberado reduz substancialmente a desmineralização do esmalte dental adjacente ao material, quando analisado em um sistema de cárie artificial.

AMENDOLA; BORGES; ARAÚJO ${ }^{4}$, em 1997, analisaram a liberação e da incorporação de flúor de: a) um cimento de ionômero de vidro (Chellon-Fil“ESP) e dois selantes (FluroShield"-Dentsply e Alpha Fluor Seal"-DFL) e b) os mesmos materiais após exposição a gel de flúor fosfato acidulado (FPA) a 1,23 por cento e gel de flúor neutro (FN) a 2 por cento. Os dados obtidos permitiram concluir que houve incorporação de flúor pelos materiais e subseqüente liberação após exposição a géis fluoretados, fazendo que estes materiais funcionem como reservatórios de flúor.

PALMA et al. ${ }^{247}$, em 1994, realizaram trabalho com intuito de quantificar e qualificar a liberação de flúor de um selante fluoretado, o Fluroshield“. Participaram deste 21 crianças de uma escola municipal da cidade de Bauru$\mathrm{SP}$, com idade entre 7 e 8 anos, com baixa prevalência de cárie e com os primeiros molares permanentes livres de cárie. Os primeiros molares foram selados com o selante fluoretado, seguindo as especificações do fabricante. A saliva foi coletada imediatamente após o selamento após intervalos de uma e duas semanas, para posterior análise de teores de flúor presente. Observaram ótima liberação de flúor na primeira hora (1,06ppm F); após 
uma semana, os níveis de flúor na saliva decresceram de forma significativa (0,232 ppm F) e, após duas semanas, a medição dos níveis de flúor indicou valores muito próximos aos do grupo controle (sem aplicação do selante), sendo $0,161 \mathrm{ppm}$ e 0,141 ppm F, respectivamente. Através desses resultados, puderam concluir que o selante fluoretado à base de resina não é eficaz na liberação de flúor por períodos prolongados. Contudo, deve ser entendido como um método que faça parte de um conjunto de medidas preventivas.

Como o Fluroshield“ contém flúor em sua composição e segundo seu fabricante, oferece ao dente maior resistência à cárie, também foi pesquisado, através da tomada de radiografias interproximais e exame clínico táctil-visual, no presente trabalho, o aparecimento de cáries proximais nos molares tratados com selante dos dois grupos, para se concluir sobre o efeito preventivo dessas lesões, exercido por este material.

Após 12 meses da aplicação do selante não se verifica nenhuma nova lesão cariosa presente nas superfícies oclusais e proximais dos 60 dentes pertencentes ao grupo de estudo.

Evidentemente o flúor e os selantes completam-se mutuamente. Cada um age onde o outro não funciona. Ambos são parte necessária de qualquer programa de prevenção à cárie.

Os selantes de escolha deverão ser aqueles que possuem flúor na sua composição visto que são auxiliares eficazes na prevenção e no combate às cáries secundárias; o Cirurgião-Dentista deverá ainda optar pelos selantes que possuam carga, pois estes apresentam maior resistência ao desgaste.

O maior objetivo da prática da Odontologia é a prevenção das doenças dos orgãos bucais. Sendo assim, selantes não são uma alternativa aos materiais restauradores. Eles representam uma alternativa com altíssima eficácia e um procedimento técnico que se for corretamente utilizado num programa preventivo poderá significantemente reduzir o desgaste da estrutura dental e posterior restauração. Isto é um motivo relevante para a utilização dos selantes na prática da Odontologia privada.

Existem justificativas para o selante ser utilizado com base e sucesso clínico, em cujas variáveis sem dúvida este sucesso vem do operador e de sua técnica.

O selante é seguro e de fácil aplicação, desde que a técnica seja rigorosamente seguida. 
Todos os dentes selados devem ser controlados clínica e radiograficamente em intervalos periódicos para verificação da integridade do selante e possível evolução de uma cárie.

A efetividade e durabilidade do selante estão relacionados intimamente com condicionamento ácido do esmalte num tempo ideal, num isolamento sem riscos de contaminação e com uma técnica de aplicação correta.

Com o conhecimento da cárie como doença infecciosa e transmissível entre seres humanos, a prevenção da infecção por estreptococos do grupo mutans deve ser realizada, já que clinicamente esta prevenção envolve procedimentos clínicos relativamente simples, tais como o controle dietético, o uso racional de flúor e a utilização dos selantes de cicatrículas, sulcos, fossas e fissuras oclusais, idealizado para obliterar ou vedar estas áreas (ANUSAVICE ${ }^{10}, 1997$ ).

Os resultados alcançados no presente trabalho confirmam que a redução de cáries oclusais com utilização dos selantes após uma única aplicação alcança níveis bastante altos ao longo dos anos, bem como as pesquisas são unânimes ao afirmarem que em todas as regiões que permanecerem totalmente seladas haverá redução de cáries, ou seja, onde houver selante presente, não haverá cárie; fato também confirmado no estudo de MCCUNE; BOJANIN; ABODEELY ${ }^{217}$, em 1979. Isto é um motivo relevante para a utilização dos selantes na prática da Odontologia privada.

A proteção mecânica ao hospedeiro conseguida através dos selantes de fossas, cicatrículas e fissuras tem prevenido a aderência e a colonização dos estreptococos do grupo mutans sobre os dentes.

No que diz respeito à seleção dos dentes a serem selados, a sugestão da maioria dos autores, entre eles RIPA ${ }^{269}$, 1980; GIFT; FREW ${ }^{127}$, 1986; NOWAK; ANDERSON ${ }^{242}$, 1990, é pelo selamento de superfícies oclusais com fissuras profundas e com má coalescência, em pacientes que estejam em risco á cárie, sem lesões cariosas extensas presentes em nenhuma face do dente a ser selado e sendo parte de um filosofia preventiva onde o selamento é uma das intervenções, devendo ainda aplicar-se outras medidas preventivas.

Quando se estabelece um programa preventivo de instalação ou de controle da doença cárie, deve-se levar sempre em consideração as condições individuais do paciente, seus hábitos de higiene, dieta e flúor, sua história odontológica anterior e, em se tratando de crianças, a história 
presente ou passada recente da saúde bucal da mãe e mais importante ainda, indicar os dentes que podem e não podem ser selados.

Este trabalho, onde todos os passos da técnica de aplicação de selante foram criteriosamente realizados confirma também que a técnica de aplicação do selante que envolve basicamente limpeza de superfície do dente, condicionamento ácido do esmalte e aplicação propriamente dita do material, além de um bom isolamento do campo, é de fundamental importância para o sucesso do tratamento, que seria fundamentado na permanência do selante no dente o maior tempo possível.

Uma vez instalada a lesão cariosa sua remoção resulta num tratamento invasivo. O preparo conservador de uma cavidade classe I requer a remoção de estrutura dentária sadia, diminuindo a resistência da estrutura dentária. Os selantes, ao contrário, como observado neste trabalho, constituem numa técnica não invasiva, altamente conservadora, sendo que até na necessidade de reaplicação deste não é preciso desgastar nenhuma estrutura dentária.

Já não se diz mais os dentes que devem e não podem ser selados, pois quando se diz podem, não se refere ao diagnóstico de higidez ou não da superfície para a aplicação do selante, mas sim à oportunidade de escolha de mais uma alternativa ou método preventivo de cárie na superfície oclusal.

Em qualquer decisão tomada ( manter, selar, restaurar ) a adoção de um programa de manutenção é primordial.

Deve-se saber diagnosticar o período crítico ("quando") para a tomada de atitudes, sejam de redução ou eliminação do agente infeccioso (higiene bucal, controle da dieta e uso racional de flúor) ou da proteção física ao hospedeiro (selantes de fossas, cicatrículas e fissuras oclusais).

NARVAl ${ }^{236}$, em 1996, discorrendo sobre a situação do quadro epidemiológico no Brasil, diz que há indícios de que a prevalência da cárie dentária está diminuindo. Os dados apontam que persiste grande variação regional e que a doença ainda se situa em patamar que a faz ser incluída, aos 12 anos na faixa de prevalência " alta", segundo a classificação adotada pela Organização Mundial de Saúde, OMS. NARVAl ${ }^{236}$ aponta 3 vertentes explicativas a esse declínio, que seriam: ampliação da disponibilidade de água tratada em todo país; a adição de compostos fluoretados aos dentifrícios e as mudanças relacionadas ao sistema de saúde brasileiro, onde encontramos profissionais que vêm realizando importantes inovações nos 
programas e concretizando ações, que, efetivamente, têm promovido a saúde bucal.

Todos os dados do Levantamento Epidemiológico Nacional ${ }^{40}$ em 1986, do Levantamento Epidemiológico do Estado de São Paulo ${ }^{293}$, em 1999, demonstram a persistente desigualdade social no Brasil, com conseqüente permanente necessidade de atenção e assistência à saúde bucal.

A aplicação do selante deve ser realizada como parte de uma filosofia preventiva, associada a aplicações periódicas de flúor, instruções sobre higiene oral e controle da dieta, além das consultas de revisão. Deve fazer parte da rotina dos consultórios odontológicos e, se possível, dos locais de assistência à saúde pública, associada aos outros métodos de prevenção, fato afirmado por POULSEN et al. ${ }^{253}$ já em 1979. Só assim se estaria promovendo saúde bucal, objetivo maior da profissão.

Em 1985, o Council on Dental Research ${ }^{7}$ já dizia que os CirurgiõesDentistas não utilizam muito os selantes pela falta de segurança em estarem ou não aplicando correta e apropriadamente estes selantes e KIDD; JOYSTON-BECHAL ${ }^{183}$, em 1994, concordaram que ainda em meados da década de 90 existia essa barreira.

Como já foi dito, o Cirugião-Dentista deve incentivar os pacientes, e seus responsáveis, a desejarem a aplicação do selante (NOWAK; ANDERSON ${ }^{242}$, 1990; LOVE ${ }^{205}$, 1993). Não existem mais razões para os profissionais continuarem com receio de selar, inadvertidamente, lesões de cáries incipientes. O processo de cárie evolui lentamente e/ou estaciona quando são seladas lesões de cáries incipientes de cicatrículas e fissuras, desde que não haja perda do selante ou infiltração (HANDELMAN ${ }^{149}$, 1983; SWIFT JUNIOR ${ }^{337}$, 1988; MERTZ-FAIRHUST et al. ${ }^{230}$, 1998).

MAIN; LEWIS; HAWKINS ${ }^{210}$, em 1997, pesquisando a utilização de selantes po 1276 Cirurgiões-Dentistas em Ontario, E.U.A., verificaram que ainda é necessária a atualização dos conhecimentos sobre indicação e efetividade da técnica de selamento aos profissionais da Odontologia; fato também verificado por CLARK; BERKOWITZ75, em 1997.

FARSI ${ }^{108}$, em 1999, afirmou que existem várias razões para a moderada utilização da técnica de selamento das superfícies oclusais como um método de prevenção de novas lesões cariosas, entre elas cita a lacuna de informações e conhecimento sobre selantes levando à insegurança na 
utilização rotineira pelos Cirurgiões-Dentistas, assim como a pouca divulgação e informação à população sobre os benefícios desta técnica, 0 que deveria ser, de acordo com FARSI ${ }^{108}$, de responsabilidade da própria classe odontológica. Ele terminou dizendo que a educação continuada dos profissionais minimizaria esta e outras deficiências na prática profissional.

Em 1998 o Ministério Federal da Educação e do Desporto ${ }^{39}$ organizou e publicou novas Diretrizes Curriculares Brasileiras para todos os cursos de graduação universitária, incluindo diretrizes para a graduação em Odontologia. Nessas Diretrizes estão incluídas referências sobre as habilidades gerais e específicas que deve ter um Cirurgião-Dentista recém graduado, encontrando-se aí determinação para que seja um profissional de saúde com ampla visão preventiva, encarando o paciente como um todo e praticando uma odontologia para promoção da saúde de cada cidadão e de toda coletividade.

É clara a necessidade de mudança de comportamento dos profissionais em dar maior atenção às técnicas preventivas, onde se inclui a aplicação de selantes nas faces oclusais dos dentes.

Pela metodologia utilizada, o presente trabalho pode ser considerado como aplicação de um programa de prevenção de cárie oclusal, já que se utilizou aplicação de selante fluoretado, educação em saúde bucal com orientação sobre técnicas de higiene dental e controle de dieta; uso tópico de flúor além dos controles aos 1, 6 e 12 meses. Acredita-se que a somatória destes fatores contribuiu para a prevenção da instalação de novas lesões cariosas, além de despertarem os pacientes para a necessidade de autocuidados na promoção da saúde bucal.

Os resultados obtidos de $100 \%$ de prevenção de novas lesões de cárie, com alcance de excelentes resultados, estão de acordo com vários trabalhos encontrados na literatura que relatam que o uso clínico de selantes deve ser sempre associado com um efetivo programa de prevenção, como os de BUONOCORE $^{54}$, 1971; TONN; RYGE ${ }^{348}$, 1982; MERTZ-FAIRHURST ${ }^{227}$, 1984; ELDERTON $^{104}$, 1985; RIPA ${ }^{271}$, 1985; SIMONSEN ${ }^{310}$, 1987; WEINTRAUB ${ }^{367}$, 1989; CASTRO et al. ${ }^{67}$, 1992; LIEBENBERG ${ }^{200}$, 1994; LEWIS $^{198}$, 1997, FARIA et al. ${ }^{107}, 1999$. 
7 - CONCLUSÕES 


\section{7 - CONCLUSÕES}

Com base nos dados obtidos e nos resultados da análise estatística, conclui-se que:

a técnica de selamento mais eficaz foi com aplicação do selante e posterior aplicação tópica de flúor, aos 6 e 12 meses de avaliação;

a permanência do selante aos 6 meses mostrou-se semelhante com e sem posterior aplicação tópica de flúor gel;

não houve presença de cárie oclusal e interproximal nos molares selados, durante os 12 meses de avaliação;

a perda parcial do selante não possibilitou a instalação de cárie em 12 meses;

a associação da aplicação tópica de fluoreto acidulado com o selante aumenta o grau de permanência deste último;

esta associação é um meio de prevenção eficaz, pois, além de aumentar o grau de permanência do selante, colabora para diminuição na incidência de cáries proximais;

o selante oclusal fotopolimerizável utilizado apresentou elevados índices de permanência em todos os períodos de estudo, principalmente para o grupo com associação do selante e a aplicação tópica de flúor ;

o selante apresentou-se efetivo, com $100,0 \%$ de permanência total e prevenção de cárie, depois de 1 ano, quando associado à posterior aplicação de flúor tópico. 


$$
\begin{array}{r}
\text { REFERÊNCIAS } \\
\text { BIBLIOGRÁFICAS }
\end{array}
$$




\section{REFERÊNCIAS BIBLIOGRÁFICAS *}

1 - AASENDEN, R.; BRUDEVOLD, F. S. MCCANN, H. The response of intact and experimentally altered human enamel to topical fluoride. Arch. oral Biol., v.13, p.543-52, 1968.

2 - ALBERT, D.A. Sealant use in public and private insurance programs, State dent. J., v. 65, n. 2, p.30-1, Feb. 1999.

3 - ALVESALO, L.; BRUMMER, R.; LEBEL, Y. On the use of fissure sealants in caries prevention. Acta odont. scand., v.35, n.3, p.155-9, May/June 1977.

4 - AMENDOLA, A. B.; BORGeS A. L. S.; ARAúJO M. A.J. Análise da liberação e da incorporação de flúor de selantes oclusais. Estudo in vitro. Rev.Odontol. UNESP, São Paulo, v.26, n.1, p.175-87, jan./jun. 1997.

5 - AMERICAN DENTAL ASSOCIATION. Council on dental materials, instruments and equipaments. Pit and fissure sealant. J. Amer. dent. Assoc., v. 107, p. 465, Sep. 1983.

6 - AMERICAN DENTAL ASSOCIATION. Council on dental materials, instruments, and equipment. Pit and fissure sealants use: an issue explored. J. Amer. dent. Assoc., v.108, p.310-22, Mar. 1984.

7 - AMERICAN DENTAL ASSOCIATION. Council on dental research. Costeffectiveness of sealants in private practice. J Amer. Dent Assoc, v.110, p. 103-7, Mar. 1985.

* Normas recomendadas para uso no âmbito da Universidade de São Paulo, com base no documento Referências Bibliográficas: exemplos, emanado do Conselho Supervisor do Sistema Integrado de Bibliotecas da USP, em Reunião de 20 de setembro de 1990 
8 - AMORIM V.C.S.A.; FIGUEIRÔA I.W.; LIRA R.V. Selantes, quando usar? Rev. Fac. Odont Pernambuco, v. 15, n.1/2, p.12-6, 1997.

9 - ANDRIONI, J.N. Estudo comparativo entre a adaptação de um selante fotopolimerizável e um de polimerização química ao esmalte dental humano aplicados após limpeza das fóssulas e fissuras por diferentes processos. Araçatuba, 1986. Tese (Livre-Docência) Faculdade Odontolologia de Araçatuba, Universidade Estadual Paulista.

10 - ANUSAVICE, K.J. Efficacy of nonsurgical management of the initial caries lesion. J. dent Educ., v.61, n.1, p. 876-95, Nov. 1997.

11 - APOSTOLIDIS, A.A.; O'BRIAN, W.J.; FAN, P.L. As reported, Dental Survey, p. 38, Oct. 1975.

12 - ARAUJO, F.B.; FIGUEREDO, M.C. Promoção de saúde em odontopediatria. In: KRIGER, L. Promoção de saúde bucal. São Paulo, Artes Médicas, 1997. p.301-12.

13 - ARNOLD, F.A. et al. Effect of fluoridated public water supplies on dental caries prevalence. Twenth year of the Grand Rapids - Muskegon study. J. Publ. HIth., v.71, p. 652-8, 1956.

14 - AST, D.B.; BUSHEL, A.; CHASE, H.D. Clinical study of caries prophylaxis with zinc choride and potassium ferrocyanide. J. Amer. dent. Ass., v.41, p.437-42, 1950.

15 - AXELSSON, P.; LINDHE, J. Effect of controlled oral hygiene procedures on caries and periodontal diease in adults. J. clin. Periodont., v.5, p. 135-51, 1978.

16 - AXELSSON, P.; LINDHE, J. Effect of controlled oral hygiene procedures on caries and periodontal disease in adults. J. clin. Periodont., v.8, p.239-48, 1981.

17 - BACKER DIRKS, O. Longitudinal dental caries study in children 9-15 years of age. Arch. oral Biol., v.6, p. 94-108, 1961.

18 - BACKER DIRKS, O. The benefits of water fluoridation. Caries Res., v. 8, p. 2-15, 1974. 
19 - BAGRAMIAN, R. A. et al. Pattern of sealant in children receiving a combination of caries-preventive methods: three-years results. J. Amer. dent. Ass. , v.98, p. 46-50, Jan. 1979.

20 - BALL, I. A. An update on fissure sealants. Dent. Update, v.13, p. 41922, 1986.

21 - BARBOSA, A. N.; GARONE FILHO, W. Selamento de fóssulas e sulcos. Rev. gaúcha Odont., v.22, n.4, p.259-69, out./dez. 1974.

22 - BARKMEIER, W.W. et al. Effects of 15 vs 60 second enamel acid conditioning on adhesion and morphology. Operat. Dent., v.11, p. 111-6, 1986.

23 - BASSO, M.L. Nuevas possibilidades en selladores de fossas y fissuras. Rev. Ass. odont. Arg., v.7, p.184-9, 1983.

24 - BELL, R.M. Indications for sealant use in a community -based preventive dentistry program. J. dent. Educ., v.48, p. 45-55, 1984.

25 - BERNARDES, L.C. et al. Avaliação clínica do selante fluroshield. Rev. gaúcha Odont., v.42, n.4, p. 224-6, jul./ago. 1994.

26 - BJARNASON, S. High caries levels: problems still to be tackled. Acta odont. scand., v. 56, n. 3, p.176-8, June 1998.

27 - BÖDECKER, C. F. A rational means of controling the evils of incipient dental caries. Dent. Cosmos, v.71, n.3, p.286-95, Mar. 1929.

28 - BOGERT, T. T. R.; GARCIA - GODOY, F. Effect of prophylaxis agents on the shear bond strength of a fissure sealant. Pediat. Dent., v.14, n.1, p.50-1, Jan./Feb. 1992.

29 - BOHANNAN, H.M. Potential use of pit and fissure sealants. Reaction and discussion of papers. J. Public. Hlth., v.42, n. 4, p. 331-7, Fall 1982.

30 - BOHANNAN, H.M. et al. Indications for sealant use in a community - based preventive dentistry program.J. dent. Educ., v. 48, p.45-55, 1984. 
31 - BOKSMAN, L.; CARSON, B. Two-year retention and caries rates of ultra seal XT and fluroshield light-cured pit and fissure sealants. Gen. Dent., v.46, n.2, p.184-7. Mar./Apr. 1998.

32 - BOSSERT,W.A. The relation between the shape of the occlusal surfaces of molars and the prevalence of decay. J. dent. Res., v.13 , p.25, 1933.

33 - BOTAZZO,C; MANFREDINI, M. A.; NARVAI, P.C. Selantes e flúor em saúde pública. Rev. gaúcha Odont., v.37 , n.2, p.155-8, mar./abr. 1989.

34 - BOWEN, R.L. Adhesive bonding of various materials to hard tooth tissues. II. Bonding to dentin promoted by a surfaces-active comonomer. J. dent. Res.,v.44, n.5, p. 906-11, Sept./Oct. 1965.

35 - BOWEN, R.L. Adhesive bonding of various materials to hard tooth tissues. III. Bonding to dentin improved by pre-treatment and the use of surface-active comonomer. J. dent. Res.,v.44, n.5, p. 903-5, Sept./Oct. 1965.

36 - BOWEN, R.L. Adhesive bonding of various materials to hard tooth tissues. IV. Bonding to dentin enamel and fluorapatite improved by the use of a surface-active comonomer. J. dent. Res., v.44, n.5, p. 911-9, Sept./Oct. 1965.

37 - BOWEN, R.L. Composite and sealant resins: past, present and future. Pediat. Dent., v.4, n.1, p.10-5, 1982.

38 - BOWEN,W.H.; TABAK. L.A. Cariologia para a década de 90. São Paulo, Ed. Santos, 1995.

39 - BRASIL. Ministério da Educação e do Desporto. Secretaria de Ensino Superior. Diretrizes curriculares dos cursos de Odontologia. Proposta da Comissão de Especialistas de Ensino de Odontologia. Brasília, 1998.

40 - BRASIL. Ministério da Saúde. Levantamento epidemiológico em saúde bucal: Brasil, zona urbana, 1986. Brasília, Divisão de saúde bucal \& Fundação de serviços de saúde pública, 1988. 137p.

41 - BRATTHALL, D. Caries, views and perspectives. Scand. J. dent. Res., v. 100, p.47-51, 1992. 
42 - BRAVO, M. et al. A 24-month study comparing sealant and fluoride varnish in caries reduction on different permanent first molar surfaces. $\mathbf{J}$. Public HIth. Dent., v.57, n.3, p. 184-6, 1997.

43 - BREAKSPERE, R.J.; CHEM, C.; WILTON, A. Factors affeting the structure of a fissure sealant at the enamel/sealant interface. Aust. dent. J., v.22, n.3, p.199-202, June 1977.

44 - BROOKS, J.D., MERTZ-FAIRHURST, C.W. A comparative study of the retention of two pit and fissure sealants one-year results. J. Prev. Dent., v.3, n.6, p. 31-4, Nov./Dez. 1976.

45 - BROOKS, J.D. et al. A comparative study of two pit and fissure sealants: three-year results in Augusta. J. Amer. dent. Ass., v.99, p.42-6, 1979.

46 - BROWN, M.R. et al. Penetration of gel and solution etchants in oclusal fissures. J. Dent. Child., v.55, n.4, p.265-8, July/Aug. 1988.

47 - BROWNBILL, J.W.; SETCOS, J.C. Treatment selections for fissure grooves of permanent molar teeth. J. Dent. Child., v.57, p. 274-8, July/Aug. 1990.

48 - BRUDEVOLD, F. et al. A study of acidulated fluoride solutions. In vitro effects on enamel. Arch. oral Biol., v.8, p. 167-77, 1963.

49 - BRUNELLE, J.A, CARLOS, J.P. Recent trends in dental caries in U.S. children and the effect of water fluoridation. J. dent. Res., v.69, p.7237, 1990.

50 - BRUNN, C.; GIVAKOV, R. Formation of CaF2 on sound enamel and in varies-like enamel lesions after different forms of fluoride applications in vitro. Caries Res., v.25, p. 96-101, 1991.

51 - BUONOCORE, M.G. A simple method of increasing the adhesion of acrilic filling materials to enamel surfaces. J. dent. Res., v.34, n.6, p.849-53, 1955.

52 - BUONOCORE, M.G. Principles of adhesive retention and adhesive restorative materials. J.Amer.dent.Ass.,v.66, n.9, p.382-91, Sept. 1963. 
53 - BUONOCORE, M.G. Adhesive sealing of pits and fissures for caries prevention, with use of ultraviolet light. J. Amer. dent. Ass., v. 80, p. 324-8, Feb. 1970.

54 - BUONOCORE, M.G. Caries prevention in pits and fissures sealed with an adhesive resin polymerized by ultraviolet light: a two-year study of a single adhesive application. J. Amer. dent. Ass., v.82, p. 1090-3, May 1971.

55 - BUONOCORE, M.G. Pit and fissure sealing. Dent. Clin. N. Amer., v.19, n.2, p.367-83, 1975.

56 - BUSSADORI, S.K.; IMPARATO, J.C.; GUEDES-PINTO, A . C. Dentística odonto-pediátrica: técnicas de trabalho e uso de materiais dentários. São Paulo, Ed. Santos, 2000.

57 - CAMLOFFSKI, E.K.; MAZUREK, A. M. G. G. Estudo comparativo da permanência de dois tipos de selantes em primeiros molares permanentes. Publicatio UEPG, v.2, n.1, p. 117-37, 1996.

58 - CAPOZZI, L. et al. Enzymatic mechanism of action of some fluorine compounds. Caries Res., v.1, p.69-77, 1967.

59 - CARDOSO, L.B.Q.; ISSAO, M. Prevalência de cáries oclusais, de acordo com o grau de erupção em primeiros molares permanentes. Rev. Odont. da USP, v.1, n.4, p. 24-31, out./dez. 1987.

60 - CARLOS, J.P.; GITTELSOHN, A.M. Longitudinal studies of the natural history of caries. II. A life-table study of caries in the permanent teeth. Arch. oral Biol., v.10, p.739-51, 1965.

61 - CARLSSON, A.; PETERSSON, M.; TWETMAN, S. 2-year clinical performace of a fluoride-containing fissure sealant in young schoolchildren at caries risk. Amer. J. Dent., v.10, n.3, p.115-9, June 1997.

62 - CARVALHO, A. C.; EKSTRAND, K. R.; THYLSTRUP, A. Results after 1 year of non-operative occlusal caries treatment of erupting permanent first molars. Community Dent. oral Epidemiol., v.19, p.23-8, 1991. 
63 - CARVALHO, J.C.; MALTZ, M. Tratamento da doença cárie. In: KRIGER, L. Promoção de saúde bucal. São Paulo, Artes Médicas, 1997. p. 95106.

64 - CARVALHO, J. C.; THYLSTRUP, A.; EKSTRAND, K. R. Results after 3 years of non-operative occlusal caries treatment of erupting permanent first molars. Community Dent. oral Epidemiol., v. 20, n.4, p.187-92, 1992.

65 - CARVALHO, R. M. et al. Padrão de liberação de flúor de cimentos odontológicos. Rev. gaúcha Odont., v.38, n.5, p.346-8, set./out. 1990.

66 - CASTRO, J.C.M. et al. Estudo "in vitro" da penetração de selantes de fóssas e fissuras no esmalte dental humano, com ou sem contaminação. Rev. bras. Odont.,v.47, n. 3, p.14-20, jul./ago. 1991.

67 - CASTRO, M.A.M. et al. Análise microscópica da penetração de selantes. Efeito do material e da forma anatômica dos sulcos oclusais. Rev. Reg. Araçatuba -Ass. paul. cirurg. Dent., v.13, p.22-5, 1992.

68 - CAUFIELD, P.W.; CUTTER, G.R.; DASANAYAKE, A. P. Initial acquisition of mutans streptococci by infants: evidence for a discrete window of infectivity J. dent. Res., v. 72, p.37-45, 1993.

69 - CAVALCANTI, E. et al. Selantes de fossas e fissuras dentais : fundamentos. Rev. Odontop., v.5, n.1, p. 21-6, jan./mar. 1997.

70 - CENTENARO, R.M. et al. Estudo comparativo de eficácia e permanência de selante oclusal com um selante resinoso e um cimento de ionômero de vidro. In: REUNIÃO ANUAL DA SOCIEDADE BRASILEIRA DE PESQUISA ODONTOLÓGICA, 16, Águas de São Pedro, 1999. ANAIS. São Paulo, SBPqO, 1999. p.71. Res.A261.

71 - CHARBENEAU, G.T.; DENNISON, J.B. Clinical sucess and potential failures after single application of a pit and fissure sealant: a four-year report. J. Amer. dent. Ass., v.98 , p. 559-64, April 1979.

72 - CHARBENEAU, G.T.; DENNISON, J.B.; RYGE, G. A filled pit and fissure sealant: 18-month results. J. Amer. dent. Ass., v. 95 , n.2, p.299-306, 1977. 
73 - CHIBINSKI, A. C. R.; CZLUSNIAK,G.D. Análise clínica da permanência de se-lantes de fóssulas e fissuras de pré-molares e primeiros molares permanentes. Publicatio UEPG., v.2, n.1, p.91-116, 1996.

74 - CHOSACK, A.; EIDELMAN, E. Effect of time from application until exposure to light on the tag lengths of a visible light-polymerized sealant. Dent. Mater., v.4, p. 302-6, 1988.

75 - CLARK, C.; BERKOWITZ, J. The relationship between the number of sound, decayed and filled permanent tooth surfaces and the number of sealed surfaces in children and adolescents. J. Publ. HIth. Dent., v.57, n.3, p. 171-5, Summer 1997.

76 - CLINE, J.T.; MESSLER, L. Long term retention of sealent aplied by inexperienced operators in Minneapolis. Community Dent. oral Epidemiol., v.7, n.4, p. 206-12, Aug. 1979.

77 - COOLEY, R. L. et al. Evaluation of a fluoride-containing sealant by SEM, microleakage, and fluoride release. Pediat. Dent., v.12, n.1, p.38-42, Feb. 1990.

78 - CROLL, T. P. The quintessencial sealant? Quintessence Int., v. 27, n.11, p. 729-32, 1996.

79 - CUETO, E. J.; BUONOCORE, M.C. Sealing of pits and fissures with an adhesive resin: its use in carie prevention J. Amer. dent. Ass., v. 75, p. 121-8, 1967.

80 - CURRO, F.A; MAINE, L. Extending sealant therapy to the adult population. N.Y. St. Dent. J., v.53, p. 32-5, 1987.

81 - CURY, J.A. Uso do flúor. In: BARATIERI, L.N. et al. Dentística: procedimentos preventivos e restauradores. Rio de Janeiro, Quintessence, 1989. Cap. 2, p.43-67.

82 - CURY, J. A. Flúor dos 8 aos 80 ? In: FELLER,C. Atualização na clínica odonto-lógica. São Paulo, Artes Médicas, 1992. Cap.26, p.375-82.

83 - CURY J. A.; SAAD J. R.C. Liberação de flúor do selante. Rev. gaúcha Odont., v.4, n.5, p.273-5, set./out. 1993. 
84 - CZLUSNIAK,G.D.; RODRIGUES, A. C. F.; VASSAO, S.J. Análise "in vitro" da penetração de selantes em sulcos e fissuras de molares e prémolares humanos segundo materiais e técnicas. Publicatio UEPG., v.3, n.3, p. 37-56, 1995.

85 - DAVIS, M.W. Success with sealants. Gen. Dent., v.46, n.2, p.176-9. Mar./Apr. 1998.

86 - DAY, C.D.; SEDWICK, H.J. Studies on the incidence of dental caries. Dent. Cosmos, v.77, p.442, 1935.

87 - DE CRAENE, L.G. et al. A clinical evaluation of a light cured fissure sealant (Helioseal). J. Dent. Child., v.56, p. 97-101, 1989.

88 - DEERY, C. et al. Integrity, maintenance and caries susceptibility of sealed surfaces in adolescents receiving regular care from general dental practioners in Scotland. Int. J. Paed. Dent., v.7, n.2, p.75-80, June 1997.

89 - DENNISON, J.B.; STRAFFON, L.H. Clinical evaluation comparing sealant and amalgam 4-year report. J. Amer. dent. Ass., v.60, n.520, p.843, 1981.

90 - DENNISON, J.B.; STRAFFON, L.H.; MORE, F.G. Evaluating tooth eruption on sealant efficacy. J. Amer. dent. Ass., v.121, n. 5, p. 6104, Nov. 1990.

91 - DENNISON, J.B. et al. Inicial leakage under pit and fissure sealants assessed by neutron activation. J.dent.Res., v.53, n.6, p.1439-44, Nov./Dec. 1974.

92 - DE PAOLA, D. F.; AASENDEN, R.S.; BRUDEVOLVD, F. The use of topically applied acidulated phosphate-fluoride preceded clinical trial. Arch. oral Biol., v.16, p.1155-63, 1971.

93 - DIAS, A.R. Efeito da profilaxia e do condicionamento ácido na infiltração marginal de um selante de fissura oclusal. Bauru, 1997. 142p. Dissertação (Mestrado) - Faculdade de Odontologia de Bauru, Universidade de São Paulo. 
94 - DIN, E. L.; VERTUAN, V.; MENDES, A.J.D. Permanência de selante oclusal autopolimerizável: avaliação clínica após 6 a 12 meses. Rev. Odont. UNESP, v.18, n. 1, p. 233 - 9, 1989.

95 - DINI, E.L. Permanência de selante oclusal autopolimerizável: avaliação clínica após 6, 12, 18 e 24 meses. Rev. bras. Odont., v. 49, n.5, p. 22 5 , set./out. 1992 .

96 - DONLY, K.J. et al. Evaluating the effects of fluoride-releasing dental materials on adjacent caries. J. Amer. dent. Ass., v.130, p.817-25, June 1999.

97 - DONNAN, M.F; BALL, I.A. A double-blind clinical trial to determine the importance of pumice prophylaxis on fissure sealant retention. Brit. dent. J., v,165, n.8, p. 283-5, Oct. 1988.

98 - DOYLE, W.A. et al. A five year study of the longevity of fissure sealants. J. Dent. Child., v.45, n.2, p.23-5, 1978.

99 - DUARTE, R.C. Efeito da combinação do método da aplicação do selante e do flúor tópico (aplicação clínica). São Paulo, 1985. Dissertação (Mestrado) - Faculdade de Odontologia da Universidade de São Paulo.

100 - DUARTE, R.C.; ISSAO, M. Efeito da combinação do método de aplicação do selante e do flúor tópico (aplicação clínica). Rev. paul. Odont., v. 9, n.3, p. 18-30, maio/jun. 1987.

101 - EARLE, J. O.; KAZIMIROFF, J.; JEFFERIES, S.R. A retrospective clinical analysis of a fluoride containing sealant/composite. J. dent. Res., v.74, p. 165, 1995. Abst. 1229.

102 - EDEN, G.T. Clinical evolution of a pit and fissure sealant for young adults. J.prosth. Dent., v. 36 , n.1, p. 51-7, 1976.

103 - EIDELMAN, E.; FUKS, A.B.; CHOSACK, A. The retention of fissure sealants: rubber dam or cotton rolls in a private practive. J. Dent. Child., v.50 n.4, p. 2590-61, July/Aug. 1983. 
104 - ELDERTON, R.J. Assement and clinical management of early caries in young adults: invasive versus noninvasive methods. Brit. dent. J., v.158, p.440-4, 1985.

105 - ELDERTON, R.J. Overtreatment with restorative dentistry: when to intervene? Int. dent. J., v. 43, p. 17-24, 1993.

106 - FAN, P. L.; SELUK, L.W.; O'BRIAN, W. J. Penetrativity of sealants. J. dent. Res., v.54, p.262-4, Mar./Apr. 1975.

107 - FARIA, G. et al. O uso do selante sobre fossas e fissuras com lesão de cárie - uma visão crítica. Jornal AORP, v. 20, n. 115, p.6, nov. 1999.

108 - FARSI, N.M.A. The effect of education upon dentists' knowledge and attitude toward fissure sealants. Odonto Stomatologie Tropicale, v.86, p.27-32, 1999.

109 - FELIPE, L.A. et al. Selamento de margens de restaurações de amálgama. Rev. Ass. paul. cirurg. Dent., v.53, n.3, p. 221-7, maio/jun. 1999.

110 - FERGUSON, F.S.; RIPA, L.W. Evaluation of the retention of two sealants applied by dental students. J. dent. Educ., v.44, n.8, p. 494-6, 1980.

111 - FERRARA, C.M. Pit and fissure sealants. N.Y. St. dent. J., v. 41, n.8, p. 536-43, Nov. 1975.

112 - FERREIRA, R.A. Em queda livre. Rev. Ass. paul. cirurg. Dent., v.52, n.2, p. 104-11, mar./abr. 1998.

113 - FERREIRA ZANDONÀ, A. G.et al. Laser fluorescence detection of demineralization in artificial occlusal fissures. Caries Res. , v. 32, p.31-40, 1998.

114 - FORREST, J.R. Caries incidence and enamel defects in areas with different levels of fluoride in the drinking water. Brit. dent. J., v.100, p.195-200, 1956. 
115 - FORSS, H.; SEPPÄ, L. Prevention of enamel demineralization adjacent to glass ionomer filling materials. Scand. J. dent. Res.,v.90, n.2, p.173-8, 1990.

116 - FORSS, H.; SAARNI, U.; SEPPÄ, L. Comparison of glass-ionomer and resin-based fissure sealants : a 2-year clinical trial. Community dent. oral Epidemiol., v.22, p.21-4, 1994.

117 - FORSS, H. et al. Plaque accumulation on glass ionomer filling materials. Proc. Finn. Dent. Soc., v.87, n.3, p.343-50, 1991.

118 - FORSTEN, L. Short and long-term fluoride release from glass ionomers and other fluoride-containing filling materials in vitro. Scand. J. dent. Res., v.98, p.179-85, 1990.

119 - FRANCO, E.B.; MAGRO, A. C.; CARVALHO, R.B. Avaliação clínica da longevidade de selantes de cicatrículas e fissuras. Rev. Fac. Odont. Bauru, v. 2, n. 2, p.64-7, abr. 1994.

120 - FUKS, A.B. et al. A comparison of the retentive properties of two filled resins used as fissure sealants. J. Dent. Child., v.49 , p. 127 - 30, 1982.

121 - FUSUAYAMA, T.; KUROSU, A. Diagnosis and distribuition of pits and fissures. J. prosth. Dent., v. 14, p. 117-26, 1964.

122 - GALARNEAU, C.; BRODEUR, J.M. La variation inter-dentistes sur le scellement dentaire. J. Canad. Dent. Ass., v. 64, n.10, p.718-25, Nov. 1998.

123 - GARCIA-GODOY, F.; GWINNETT, A.J. Penetration of acid solution and gel in occlusal fissures. J.Amer.dent. Ass., v.144, p. 809-10, 1987.

124 - GARONE NETTO, N.; GARONE FILHO, W. Interface resina esmalte condicionado, analisada por microscópio eletrônico de varredura. Rev. Ass. paul. cirurg. Dent., v.29, n.4, p.35-9, 1975.

125 - GIACHETTI, N.J.; PAGANI. R. Ataque ácido e adesivos em Odontologia. A técnica do ataque ácido em Odontopediatria. Ars. Cur. Odont., v.5, n.41, p. 16-28, jul. 1978. 
126 - GIBSON, S.; WILLIANS, S. Dental caries in pre-school children: associations with social class, tooth brushing habit and consupti on of sugar-containing foods. Caries Res., v.33, p.101-3, 1999.

127 - GIFT, H.C.; FREW, R.A. Sealants: changing patterns. J. Amer. dent. Ass., v.112, p. 391-2, Mar. 1986.

128 - GILLCRIST, J. A.; VAUGHAN, M.P. Pit and fissure sealants: a review of rationale, effectiveness and utilization. J. Tenn. dent. Ass., v.77, n.2, p.27-31, Apr. 1997.

129 - GILLCRIST, J. A. et al. Clinical sealant retention following two different tooth-cleaning techniques. J. Public. HIth. Dent., v.58, n.3, p.254-6, Summer 1998.

130 - GILPATRICK, R.O.; ROSS, J.A.; SIMONSEN, R.J. Resin-to-enamel bond strengths with various etching times. Quintessence Int., v.22, p. 47-9, 1991.

131 - GILPIN, J.L. Pit and fissure sealants: a review of the literature. J. dent. Hyg., v.71, n.4, p.150-8. Summer 1997.

132 - GOING, R. E.; LOESCH, R. Caries in sealants resin, long term sudy. J. Amer.dent.Ass., v.97, p.455-62, Sept. 1978.

133 - GOING, R. E. et al. Two year clinical evaluation of a pit and fissure sealant. Part I: retention and loss of substance. J. dent. Ass., v.92,n. 2, p. 388-97, Feb. 1976.

134 - GOING, R. E. et al. Two year clinical evaluation of a pit and fissure sealant. Part II: caries initiation and progression. J.Amer.dent.Ass., v.92, n.3, p. 578-85, Mar. 1976.

135 - GOMES, A. P. A.; TOLEDO, O. Idade para aplicação do selante: erupção dos primeiros molares permanentes. Importância na elaboração de um programa de aplicação de selantes de fóssulas e fissuras. Rev. gaúcha Odont., Porto Alegre, v.40, n.2, p.127-9, mar./abr. 1992 . 
136 - GOODMAN, L.A. Simultaneous confidence intervals for contrasts among multinomial populations. Annals of mathematical statistics, v.35, n.2, p.716-25, 1964.

137 - GOODMAN, L.A. On simultaneous confidence intervals for contrasts among multinomial proportions. Technometrics, v.7, n.2, p.247-54, 1965.

138 - GOURLEY, J.M. A two-year study of a fissure sealant in two Nova Scotia communities. J. Public. HIth. dent., v.35, n.2, p.132-7, Spring 1975.

139 - GOURLEY, J.M. The use of sealants for reduction of caries frequency level in oclusal pits and fissures. Oral HIth., v.65 , n.11, p. 37-42, Nov. 1975.

140 - GRAVES, R.C.; BURT, B.A. The pattern of the carious attack in children as a consideration in the use of fissure sealants. J. Prevent. Dent., v.2, n.3, p. 28-32, 1975.

141 - GRON, P. Chemistry of topical fluorides. Caries Res., v.11, p.172-204, 1977.

142 - GWINNETT, A. J. Caries prevention through sealing of pits and fissures. J. Canad. dent. Ass., v.37, n.12, p.458-61, 1971.

143 - GWINNET, A.J. Human prismless enamel and its influence on sealant penetration. Arch. oral Biol., v.18, p.441, 1973.

144 - GWINNETT, A. J. Pit-and-fissure sealants: an overview of research. J. Publ. HIth. Dent., v.42, n.4, p. 298-303, Fall 1982.

145 - GWINNETT, A.J.; BUONOCORE, M. G. Adhesives and caries prevention. Brit. dent. J., v.119, p. 77, July 1965.

146 - GWINNETT, A.J.; BUONOCORE, M.G. A scanning electron microscopic study of occlusal surfaces conditioned for adhesive sealing. Arch. oral Biol., v.17, p.415-23, Mar. 1972. 
147 - GWINNETT, A. J.; MATSUI, A. A study of enamel adhesives: the physical relationship between enamel and adhesive. Arch. oral Biol., v.12, p.1615-20, 1967.

148 - GWINNETT, A. J.; RIPA, L.W. Penetration of pit and fissure sealants into conditioned human enamel in vivo. Arch. oral Biol., v.18, p. 435-9, 1973.

149 - HANDELMAN, S.L. Effect of sealant placement on oclusal caries progression. Clin. Prevent. Dent., v. 4, p.11-6, 1983.

150 - HANDELMAN, S. L.; BUONOCORE, M. G.; SCHOUTE, P. C. Progress report on the effect of a fissure sealant on bacteria in dental caries. J. Amer. dent. Ass., v.87, n.2, p.1189-91, Nov. 1973.

151 - HANDELMAN, S. L.; WASHBURN, F.; WOPPERER, P. C. Two-year report of sealant effect on bacteria in dental caries. J. Amer. dent. Assoc., v.93, n.11, p.967-70, Nov. 1976.

152 - HARDISON, J.R. et al. Retention of pit and fissure sealant on the primary molars of 3 and 4-year old children after 1 year. J. Am. dent. Ass., v.114, p.613-5, 1987.

153 - HARRISON, L. Rationale and guidelines for pit and fissure sealants. ASDC. J. Dent. Child., v.50, n.4 p.156, 1983.

154 - HELLE, A. Two fissure sealants tested for retention and caries reduction in finnish children. Proc. Finn.dent.Soc., v.71, n.3, p.91-5, June 1975.

155 - HENNON, D.K.; STOOKEY, G.K.; MUHLER, J.C. Prevalence and distribution of caries in pre-shool children. J. Amer. dent. Ass., v. 79, p.1405-14, 1969.

156 - HEROLD, E.L. Cynoacrylates in dentistry: a review of the of the literature. J. Amer. dent. Ass., v.56, n.4, p. 331-4, Apr. 1990.

157 - HICKS, M. J.; FLAITZ, C.M. Caries-like lesion formation around fluoridereleasing sealant and glass ionomer. Amer. J. dent., v.5, n.6, p.32934, Dec. 1992. 
158 - HICKS, M.J.; SILVERSTONE, L.M. The effect of sealant application and sealant loss on caries-like lesion formation in vitro. Pediatr. Dent., v.4, n.2, p.111-4, 1982.

159 - HINDING, J. Extended cariostasis following loss of pit and fissure sealant from human teeth. J. Dent. Child., v.41, n.3, p. 201-3, 1974.

160 - HOROWITZ, H. S. The potential of fluorides and sealants to deal with problems of dental decay. Pediatric. Dent., v.4, p. 286-95, 1982.

161 - HOROWITZ, H.S. Commentary on and recommendations for the proper uses of fluoride. J. Public. HIth. dent., v.55, n.1, p.57-62, Winter 1995.

162 - HOROWITZ, H.S.; HEIFETZ, S.B.; MCCUNE, R.J. The effectiveness of an adhesive sealant in preventing occlusal caries: findings after two years in Kalispell, Montana. J. Amer. dent. Ass.,v.89,n.4, p.885-90, Oct. 1974.

163 - HOROWITZ, H.S.; HEIFETZ, S.B; POULSEN, S. Retention and effectiveness of a single application of an adhesive sealant in preventing occlusal caries: final report after five years of a study in Kallispell, Montana. J. Amer. dent. Ass., v.95, p.133-9, 1977.

164 - HOUPT, M.; SHEY, Z. Clinical effectiveness of an autopolimerized fissure sealant (Delton) after thirty three months. Ped. Dent., v.1, n.3, p. 165-8, Sept. 1979.

165 - HOUPT, M.; SHEY, Z. The effectiveness of a fissure sealant after six years. Pediat. Dent., v.5, n.2, p.104-6, June 1983.

166 - HUNT, R.J., KOROUT, F.J.; BECK, J.D. The use of pit and fissure sealants in private practices. J.dent.Child., v.51, p.29-33, 1984.

167 - HYATT, T.P. Prophylactic odontonomy : the cutting into the toth for the prevention of disease. Dent. Cosmos, v.65, p.243-1, 1923.

168 - HYATT, T.P. Observable and unobservable pits and fissures. Dent. Cosmos, v.73, p. 586-92, 1931. 
169 - ISHIKIRIAMA, A.; TOMITA, N.E.; MAGELA, G. Selante em saúde pública. Rev. Fac. odont. Bauru, v.2, n.2, p. 59-63, 1994.

170 - ISLER, S.L.; DOLINE, S.L. Pratical aplication of pit and fissure sealants. A seven-year retrospective study. Clin. prev. Dent., v.3, p.18-20, 1981.

171 - ISMAN, R.; KIZER, K.W. Preventive dentistry update on dental sealants. Western J. Medicine, v. 146, p. 631-2, May 1987.

172 - ISSAO, M.; ANDO, T. Selantes de fóssulas e fissuras: método de prevenção de cáries oclusais. Encicl. bras. Odont., v.1, n.2, p.23-9, 1983.

173 - JACKSON, D.; MURRAY, J.J.; FAIRPO, C.G. The effect of fluoride in drinking water on the number of cavities in the teeth of 15 years old children. Brit. dent. J., v.13, n.5, p. 480-1, June 1973.

174 - JENSEN, M. E. Anti-caries effects of current restorative materials. J. dent. Res., v.67, p. 110, 1998. Abst. S62.

175 - JENSEN, O.E.L.; BILINGS, R.J.; FEATHERSTONE, J.D.B. Clinical evaluation of fluroshield pit and fissure sealant. Clin. Prev. Dent., v.12, n.4, p.24-7, Oct./Nov. 1990.

176 - JENSEN, M.E. et al. Effects of fluoride releasing fissure sealant on artificial enamel caries. Amer. J. dent., v.3, p.75-8, 1990.

177 - JOHNSON, S. Dental caries continues downward trend in children. J. Amer. dent. Ass., v. 117, p. 625, 1988.

178 - JOHNSON, W.W.; ARMANAZI, Y.; SHARP, H. Sealant leakage with and without isolation. J. Tenn. dent. Ass., v. 77, n.1, p.32-4. Jan. 1997.

179 - KAY, E.J. Caries prevention - based or evidence? Or an act to faith? Brit.dent. J., v.185, n.9, p.432-3, Nov. 1998.

180 - KAY, E.J.; LOCKER, D. Is dental health education effective? A systematic review of current evidence. Community Dent. Oral. Epidemiol., v.24, p. 231-5, 1996. 
181 - KEMPER, R.N. Selantes de fóssulas e fissuras. In : MENAKER, L. Cáries dentárias, bases biológicas. Rio de Janeiro, Guanabara Koogan, 1984. 461p.

182 - KEMPER, R.N. Selantes de fóssulas e fissuras. In: NEWBRUN,E. Cario-logia. 2. ed. São Paulo, Ed. Santos, 1988. Cap.10, p.291305.

183 - KIDD, E. A. M.; JOYSTON-BECHAL, S. Update on fissure sealants. Dental Update, v. 38, n.4, p. 323-6, Oct. 1994.

184 - KLEIN H.; KNUTSON J. W . Studies on dental caries. XIII. Effect of ammoniacal silver nitrate on caries in the first permanent molar. J. Amer. dent. Ass., v.29, n.8, p.1420-6, 1942.

$185-\mathrm{KOCH}, \mathrm{G}$; HATIBOVIC-KOFMAN, S. Glass ionomer cement as a fluoride release system in vivo. Swed. dent. J., v.14, n.6, p.267-73, 1990.

186 - KOH, S.H.; CHAN, J.T.; YOU, C. Effects of topical fluoride treatment on tensile bond strength of pit and fissure sealants. Gen. dent., v. 46, n.3, p.278-80, May-June 1998.

$187-\mathrm{KOH}, \mathrm{S} . \mathrm{H}$. et al. Topical fluoride treatment has no clinical effect on retention of pit and fissure sealants. J. G.T. Houst. Dent. Soc., v. 67, n. 2, p.16-8, Sept. 1995.

188 - KÖNIG, K.G. Dental morphology in relation to caries resistance with special reference to fissures as susceptible areas. J. dent. Res., v. 42, p.461-76, 1963.

189 - KOPEL, H.M. Pretreating enamel to increase adhesion of plastic restorative materials - the etch technic. J.S.Calif. dent.Ass., v.39, n.9, p.752-5, Sept. 1971.

190 - KOPEL, H.M.; GRENOBLE, D.E. The pit and fissure sealants: a critical review. J. Mich. dent. Ass., v.55, p.32-7, Feb. 1973.

191 - KRASSE, B. Risco de cáries: guia prático para controle e assessoramento. São Paulo, Quintessence, 1988. 113p. 
192 - KRIGER, L. Promoção de saúde bucal. São Paulo, Artes Médicas, 1997.

193 - KULA, K.; WEBB, E.L.; KULA, T. Effect of 1 and 4 minute treatments of topical fluorides on a composite resin. Pediatr. Dent. , v.18, p. 24-8, 1996.

194 - LEE, H.L. Letter: fissure sealants. Brit. dent. J., v.137, n.3, p.85, Aug. 1974.

195 - LEINFELDER, K. F. Ask the expert. Anything new in pit and fissure sealants? J. Amer. dent. Ass., v.130, n.4, p.533-4, Apr. 1999.

196 - LEVERETT, D.H.; HANDELMAN, S.L. Cost effectiveness of sealants as an alternative to conventional restorations. J. dent. Res., v.57, n. 360, p.1128, 1978.

197 - LEVERETT, D.H. et al. Use of sealants in the prevention and early treament of carious lesions: cost analysis. J. Amer. dent. Ass., v. 106, p.39-42, Jan. 1983.

198 - LEWIS, A.M. Sealing caries out or in? Dent. Today, v. 16, n.9, p.104-7, Sept. 1997.

199 - LEWIS, D.W.; HARGREAVES, J.A. Epidemiology of dental caries in relation to pits and fissures. Brit. J. dent., v.138, p.345, 1975.

200 - LIEBENBERG, W.H. The fissure sealant impasse. Quintessence Int., v.25, n.11, p.741-5, 1994.

$201-\mathrm{LI}, \mathrm{S} . \mathrm{H}$. et al. Evaluation of the retention of two types of pit and fissure sealants. Community Dent. oral Epidemiol., v.9 , p.151-8, 1981.

202 - LLODRA, J.C. et al. Factors influencing the effectiveness of sealants - a meta-analysis. Community Dent. oral Epidemiol., v.21, p.261-8, 1993.

203 - LOESCHE, W. J. Cárie dental: uma infecção tratável. Rio de Janeiro, Cultura Médica, 1993. 349 p. 
204 - LOVADINO, J.R. et al. Avaliação de dois materiais utilizados como selante oclusal: ionômero x compósito. Rev. Ass. paul. Cirurg. Dent., v.48, n.1, p.1243-6, jan./fev. 1994.

205 - LOVE, W.C. et al. The efficacy of dental selants for an adult population. Oper. Dent., v.18, n.5, p. 195-202, Sept./Oct. 1993.

206 - LOW, T. et al. The bonding of a polymeric fissure sealant to topical fluoride-treated teeth. J. Oral. Rehabil., v.2, p.303-7, 1975.

207 - LOW, T. et al. Influence of the topical application of fluoride on the in vitro adhesion of fissure sealants. J. dent. Res., v.56, p.17-20, 1977.

208 - LOW, T. et al. The combined application of topical fluoride and fissure sealant: results after 2 years. J. Oral. Rehabil., v.9, p.1-5, 1982.

209 - LYGIDAKIS, N.A.; OULIS,K.I.; CHRISTODOUL, A. Evaluation of fissure sealants retention lowing four different isolation ans surface preparation techniques: for years clinical trial. J. Clin. Pediatr. Dent., v.19, n.1, p.23-5, 1994.

210 - MAIN, P.A.; LEWIS, D.W.; HAWKINS, R.J. A survey of general dentists in Ontario. Part I : sealant use and knowledge. J. Canad. dent. Ass., v.63, n. 7, p.542-53, July/Aug. 1997.

211 - MAIN, C. et al. Surface treatment studies aimed at streamlining fissure sealant application. J.oral Rehab., v.10, n.4, p.307-17, July 1983.

212 - MANTON, D.J.; MESSER, L.B. Pit and fissures sealants: another major cornerstone in preventive dentistry. Aust. dent. J., v.4, n.1, p.22-9, 1995.

213 - MARSHALL, C.D.; SEDWICK, H.J. Studies on the incidence of dental caries. Dental Cosmos, v.77, p. 442-52, May 1935.

214 - MARSHAL, G.W.; OLSON, L.M.; LEE, C.V. SEM investigation of the variability of enamel acid etching for pit and fissure sealants. J. dent. Res., v.54, p.1223-31, 1975. 
215 - MARTHALER, T.M.; O'MULLANE, D.M.; VRBIC, V. The prevalence of dental caries in Europe 1990 - 1995. Caries Res., v. 30, n. 4, p. 23755, 1996.

216 - MCCOURT, J.W.; COOLEY, R.L.; HUDDLESTON, A.M. Fluoride release from fluoride-containing liners/bases. Quintessence Int., v.21, n.1, p.41-5, 1990.

217 - MCCUNE, R.J.; BOJANINI, J.; ABODEELY, R.A. Effectiveness of a pit and fissure sealants in the prevention of caries three-year clinical results. J.Amer. dent.Ass., v.99, n.4, p.619-23, Oct. 1979.

218 - MCKENNA, R.F.; GRUNDY, G.E. Glass ionomer cement fissure sealants applied by operative dental auxiliares-retention after oneyear. Aust.dent.J., v.32, n.3, p.200-3, June 1987.

219 - MCLEAN, J.W. Estado actual y futuro del uso clínico de los cementos de ionomero de vitreo. Rev. Ass. Odont. Argent., v.79, n.3, p.51764, July/Sept. 1991.

220 - MCLEAN, J.W.; WILSON, A. D. Fissure sealing and filling with an adhesive glass-ionomer cement. Brit. dent. J., v.136, n.7, p. 269-76, Apr. 1974.

221 - MCLEAN, J.W.; WILSON, A. D. The clinical development of the glassionomer cements: formation and proporties. Aust. dent. J., v.22, n.1, p.31-6, Feb. 1977.

222 - MEDINICK, G.A.; LOESCHE, W.J.; CORPRON, R.E. A bacterial evaluation of an occlusal sealant as barrier system in humans. J.Dent.Child., v. 41, n.5, p.356-60, Sept./Oct. 1974.

223 - MEJARE, I.; MJÖR, I.A. Glass ionomer and resin based fissure sealants: a clinical study. Scand. J. dent. Res., v. 98, p. $345-50$, 1990.

224 - MENAKER, L. Cáries dentárias: bases biológicas. Rio de Janeiro, Guana-bara Koogan, 1984. 461 p.

225 - MERTZ-FAIRHURST,E.J. Current status of sealant retention and caries prevention. J. Dent. Educat., v.48,n 2, p. 18-26, 1984. 
226 - MERTZ-FAIRHURT, E.J. et al. Comparative study of two pit and fissure sealants: results after 4 years in Augusta. J. Amer. dent. Ass., v.99, p.235-8, 1981.

227 - MERTZ-FAIRHURST, E.J. et al. A comparative study of two pit and fissure sealants: six-year results in Augusta, Ga. J. Amer. Dent. Ass., v.105, n.2, p. 237-9, 1982.

228 - MERTZ-FAIRHURST, E.J. et al. A comparative study of two pit and fissure sealants: 7-year results in Augusta, Ga. J. Amer. dent. Assoc., v.109, p. 252-5, 1984.

229 - MERTZ-FAIRHURST, E. J. et al. The anti-caries efficacy of sealants rests essentially on the crucial factor. A comparative clinical study of two pit and fissure sealants: 7-year results in Augusta, GA. Dental. Health., v. 30, n.4, p. 3-7, 1991.

230 - MERTZ-FAIRHUST, E.J. et al. Ultraconservative and cariostatic sealed restorations: results at 10 years. J. Amer. dent. Ass., v.129, n.1, p.55-66, Jan. 1998.

231 - MILLER, J. Clinical investigations in preventive dentistry. Brit. dent. J., v.91, p.92, 1951.

232 - MILLER, W.D. The preventive treatment of teeth with special reference to nitrate of silver. Dent. Cosmos, v.47, p. 913-22, 1905.

233 - MITCHELL, L.; MURRAY, J.J. Caries in fissure-sealed teeth: a retrospective evaluation. J. Paed. Dent., v.6, p.91-6, 1990.

234 - MONUS, A.; GRENOBLE, D.E. An in vivo study of enamel remineralization after acid etching. South. Calif. Dent. J., v.34, p.747, Oct. 1971.

235 - MOORE, C.E.; JACKSON, G.S. Pit and fissure sealants: one more time. J. Canad. Dent. Ass., v.54, n.10, p. 728-30, Oct. 1988.

236 - NARVAI, P.C. Está ocorrendo um declínio de cárie no Brasil? Jornal da ABOPREV, v.7, p.12, mar./abr. 1996. 
237 - NAVARRO, M.F.; CORTES, D.F. Avaliação e tratamento do paciente com relação ao risco de cárie. Maxi-odonto: dentística, Bauru, v.1, n.4, p.1-35, jul./ago. 1995.

238 - NAVARRO, M.F.L. et al. Fluoride release from fluroshield, heliomolar and chelon-silver. J.dent. Res., v.70, n.4, p.637, 1991.

239 - NEWBRUN, E. Cariologia. 2 ed. São Paulo, Ed. Santos, 1990.

240 - NEWBRUN,E. Preventing dental caries: breaking the chain of transmission. J. Amer. dent. Ass.,v.123, p.55-9, June 1992.

241 - NIH CONSENSUS DEVELOPMENT CONFERENCE SUMMARY. Dental Sealants in the prevention of tooth decay. Brit. dent. J., p. 295-8, Apr. 1984.

242 - NOWAK, A.J.; ANDERSON, J.L. Preventive dentistry for children: a review from 1968-1988. J. Dent. Child., v.57, p.31-37, 1990.

$243-\mathrm{OHKUBO}, \mathrm{N}$. et al. A retention comparison of two sealants. Bull Tokio dent. Coll., v.23, n.4, p.201-19, 1982.

244 - OKIDA, R. C.; MANDARINO, F.; CURY, J. A. Avaliação da liberação e da incorporação de flúor ao esmalte íntegro e ao criado utilizando-se materiais fluoretados submetidos a ciclagens de desmineralização e remineralização. Rev. Odont. UNESP, v.26, n.133-43, 1997.

245 - OVREBO, R.C.; RAADAL, M. Microleakage in fissures sealed with resin or glass ionomer cement. Scand. J. dent. Res., v. 98, p.66-69, 1990.

246 - PAGANI, C.; GIACHETTI, N.J. Ataque ácido e adesivos em Odontologia VII - Fatores que interferem adversamente na adesão. Ars. Curandi Odontol., v.5 , n.1, p.11-8, 1978.

247 - PALMA, R.G. et al. Avaliação clínica dos teores de flúor liberados por um selante fluoretado. Rev. Odont. Univ. São Paulo, v. 8, n.3, p.181-5, jul./set. 1994. 
248 - PARK, K. et al. Comparison of shear strength, fracture patterns and microleakage among unfilled, filled and fluoride-releasing sealants. Pediatr. Dent., v.15, n.6, p. 418-21, Nov./Dec. 1993.

249 - PERCINOTO, C. et al. Penetration of light-cured glass ionomer and a resin sealant into occlusal fissures and etched enamel. Amer. J. Dent., v.8, n.1, p. 20-2, Feb. 1995.

250 - PHILLIPS, R.W. Advancements in adhesive restorative dental materiais. J. dent. Res., v.45, n.2, p.1662-7, 1966.

251 - PINTO, V. G.; LIMA, M. P. Redução da cárie dental no Brasil: o estudo do SESI. In:CONGRESSO INTERNACIONAL DE ODONTOLOGIA DA ABO/DF. Brasília, 1995.

252 - PINTO, V.G. Epidemiologia das doenças bucais no Brasil, In: KRIGER, L. Promoção de saúde bucal. São Paulo, Artes Médicas, 1997. p. 29-35.

253 - POULSEN, S. et al. Evaluation of a pit and fissure sealing program in a public dental health service after 2 years. Community Dent. oral Epidem., v.7, p. 154-7, 1979.

254 - POWELL, L. V. Predição de cárie. Encarte científico ABOPREV, v.06, p.8, jul. 1999.

255 - PRADO, C. Comportamento clínico de um selante Bis-GMA e um selante de ionômero de vidro (Estudo comparativo "in vitro") São Paulo, 1991, 124p. Tese (Doutorado)- Faculdade de Odontologia da Universidade de São Paulo.

256 - PRADO, C.; GARONE NETTO, N. Selante em molares decíduos e permanentes: avaliação "in vitro". Rev. Odont. Univ. São Paulo, v.4, n.4, p. 329-33, out. /dez. 1990.

257 - PRIME, J.M. Prophilatic treatment of pit and fissures. Dent. Cosmos, v. 68, p. $97,1926$. 
258 - RAADAL, M., UTKILEN, A.B., NILSEN, O.L. A two-year clinical trial comparing the retention of two fissure sealants. Int. pediatr. Dent., v.1, p.77-81, 1991.

259 - RAADAL, M. et al. Fissure sealing on permanent first molars in children receiving a high standard of prophylactic care. Community Dent. oral Epidem., v.12, n.3, p.65-8, Sept. 1984.

260 - RANTALA, E.V. Carie incidence in 7-9 years-old children after fissure sealing and topical fluoride therapy in Finland. Community. Dent. oral Epimem., v.7, n.3, p.213-7, Aug. 1979.

261 - RAWLS, H.R. Preventive dental materials : sustained delivery of fluoride and other therapeutic agents. Adv. Dent. Res., v.5, p.50-5, 1991.

262 - REGO, M. A.; ARAÚJO, M. A. M. A 2-year clinical evaluation of fluoridecontaining pit and fissure sealants placed with an invasive technique . Quintessence Int., v.27, n. 2, p.99-103, Feb. 1996.

263 - REGO, M.A.; SILVA, R.C.S.P.; ARAÚJO, M.A.M. Avaliação clínica de selan-tes de fossas e fissuras com e sem flúor, pelo período de dois anos. Rev. bras. Odont., v.55, n.3, p.145-50, maio/jun. 1998.

264 - REISBICK, M. H. et al. Benefit from sealants in a moderately fluoridated community. J. Calif. dent. Ass., v. 10, n.3, p. 53-6, May 1982.

265 - RETIEF, D.H. Effect of conditioning the enamel surface with phosphoric acid. J. dent. Res., v.52, n.2, p.333-41, Mar./Apr. 1973.

266 - REUTERVING, G.K.; DIJKEN, J.W.V. A three-year follow-up of glass ionomer cement and resin fissure sealants, J. Dent. Child., v.62, n.2, p.108-10, Mar./Apr. 1995.

267 - RICHARDSON, A.S.; GIBSON, G.B.; WALDMAN, R. Chemically polymerized sealant in preventing occlusal caries. J. Canad. dent. Ass., v.46, p. 259-60, 1980.

268 - RIPA, L.W. Occlusal sealing: rationale of the technique and historical review. Amer. Soc. Prev. dent. J., v.3, p.32-9, Jan./Feb. 1973. 
269 - RIPA, L.W. Occlusal sealants: rationale and review of clinical trials. Int. dent. J. , v. 30, n.2, p. 127-39, 1980.

270 - RIPA, L. W. Potential use of fissure and pit sealants. Reaction and discussion of papers. J. Publ. Hlth. Dent., v.42, n.4, p. 327-31, Fall 1982.

271 - RIPA, L.W. The current status of pit and fissure sealants. A review. J. Canad. dent. Ass., v. 51, p. 367-80, 1985.

272 - RIPA, L.W. Sealants revisited: an update of the effectiveness of pit and fissure sealants. Caries Res., v.27, p.77-82, 1993.

273 - RIPA, L.W.; COLE, W.W. Occlusal sealing and caries prevention: results 12 months after a single application of adhesive resin. J. dent. Res., v.49, p.171-3, 1970.

274 - RIPA, L.W.; LESKE, G.S.; FORTE, F. The combined use of pit and fissure sealants and fluoride mouthrinsing in second and third grade children: one-year clinical results. Pediatr. Dent., v.8, p. 158-62, 1986.

275 - RIPA, L.W.; LESKE, G.S.; VARMA, A.O. Longitudinal study of the caries susceptibility of occlusal and proximal surfaces of first permanent molars. J. Publ. HIth. Dent., v.48, n.1, p. 8-13, Winter 1988.

276 - ROBERTS, M.W. et al. Evaluation of autopolymerizing fissure sealant as a vehicle for slow release of fluoride. Pediat. Dent., n.6, p.145-147, 1984.

277 - ROCCA, R. A. et al. Efeito da ingestão de água fluoretada na prevalência de cárie e perda de primeiros molares permanentes. Rev. Ass. paul. cirurg. dent., v.33, p.50-9, 1979.

278 - ROCK, W.P. Fissure sealants: results obtained with two different sealants after one year. Brit. dent. J., v. 133, p.146-51, 1972.

279 - ROCK, W.P. Results obtained with two different bis - GMA type sealants after one year. Brit. dent. J., v.134, p.193-6, 1973. 
280 - ROCK, W.P. Fissure sealants: further results of clinical trials. Brit. dent. J., v.136, n.7, p.317-21, 1974.

281 - ROCK, W.P. The effect of etching of human enamel upon bond strengths with fissure sealant resins. Arch. oral Biol., v. 19, n.10, p.873-7, Oct. 1974.

282 - ROCK, W.P. The effectiveness of fissure sealant resins. J. Dent. Educ., v.48, n.2, p.27- 31, Feb. 1984.

283 - ROCK, W.P.; ANDERSON, R. J. A review of published fissure sealants trials using multiple regression analysis. J. Dent., v.10, n.1, p.39-43, 1982.

284 - ROCK, W.P.; BRADNOCK, G. Effect of operator variability and patient age on the retention of fissure sealant resin: 3-year results. Community Dent. oral Epidem., v. 9, p.207-9, 1981.

285 - ROCK, W.P.; EVANS, R.I.W. A comparative study between a chemically polymerized fissure sealant resin and a light-cured resin. Brit. dent. J., v.152, p. 232-4, 1982.

286 - ROCK, W.P; WEATHERILL, S.; ANDERSON, R.J. Retention of three fissure sealant resins. The effects of etching agent and curing method. Results over 3 years. Brit. dent. J., v.168, n.8, p.323-5, Apr. 1990.

287 - ROCK, W.P. et al. The visibility of clear and opaque fissure sealants. Brit. dent. J., v.167, p.395-6, 1989.

288 - RODER, D. M.; SUNDRUM, P. The sealing of fissures in a school dental programme. Austr. dent. J., v.21, n.6, p. 491-4, Dec. 1976.

289 - ROHR, M.; MAKINSON, O. F.; BURROW, M.F. Pit and fissures: morphology. J. Dent. Child., v.58, p. 97-103, 1991.

290 - ROMCKE, R.G. et al. Retention and maintenance of fissure sealants over 10 years. J. Canad. dent. Ass., v.56, n.3, p.235-7, Mar. 1990.

291 - RYGE, G.; BASKO, P. The future of pit and fissure sealants. J.Amer. Soc. Prev.dent., v.3, n.7, p.54-7, Jan./Feb. 1983. 
292 - SALLES, C.L.F. et al. Avaliação da permanência de selantes em molares decíduos e permanentes. In: REUNIÃO ANUAL DA SOCIEDADE BRASILEIRA DE PESQUISA ODONTOLÓGICA, 16, Águas de São Pedro, 1999. ANAIS. São Paulo, SBPqO, 1999. p.163. Res. B249.

293 - SÃO PAULO. SECRETARIA DE ESTADO DA SAÚDE. FAC. DE SAÚDE PÚBLICA DE SÃO PAULO. Levantamento epidemiológico em saúde bucal: Estado de São Paulo, 1998. São Paulo, 1999. 32p.

294 - SCHERER, W. et al. Antimicrobial properties of glass-ionomer cements and other restorative materials. Oper. Dent., v.14, n.2, p.77-81, 1989.

295 - SCHROTENBOER, H.G. Fluoride benefits -after 36 years. J. Amer. dent. Ass., v.102, April 1981.

296 - SERRA, M.C.; PIMENTA, L.A.F.; PAULILLO, L.A.M.S. Dentística e manu-tenção de saúde bucal, In: KRIGER, L. Promoção de Saúde Bucal; São Paulo, Artes Médicas, 1997, p.203-15.

297 - SHEYKHOLESLAM, Z.; HOUPT, M. Clinical effectiveness of an autopolymerized fissure sealant after 2 years. Community Dent. oral Epidem., v.6 , p.181-4, 1978.

298 - SHEYKHOLESLAM, Z. et al. Effects of fluorides on the bonding of resins to phosphoric acid- etched bovine enamel. Arch. oral Biol., v.17, p.1037-45, 1972.

299 - SILVA, R.C.S.P.; ARAÚJO, M.A.M.; REGO, M.A. Avaliação clínica de selantes de fóssulas e fissuras: efeito de materiais e tempo de análise. Rev. Odont. UNESP, v.25, n.2, p.237-45, 1996.

300 - SILVA, R.C.S.P.; REGO, M.A.; ARAÚJO, M.A.M. Uso do cimento de ionômero de vidro fotoativado e selante com carga e flúor no selamento oclusal.. Rev. Odont. UNICID, v.8, n.2, p.95-102, jul./dez. 1996.

301 - SILVERSTONE, L.M. Fissure sealants. Laboratory studies. Caries Res., 
v.8, p. 2-26, 1974.

302 - SILVERSTONE, L.M. Fissure sealants: the susceptibility to dissolution of acid-etched and subsequently abraded enamel in vitro. Caries Res., v.11, p.46-51, 1977.

303 - SILVERSTONE, L.M. The use of pit and fissure sealants in dentistry prevent status and future developments. Pediat. Dent., v.4, p.16-21, 1982.

304 - SILVERSTONE, L.M. Fissure sealants: the enamel-resin interface. J. Public. HIth. Dent., v.43, p.205-15, 1983.

305 - SILVERSTONE, L.M. et al. Dynamic factors affecting lesions initation and progression in human dental enamel II. Surface morphology of sound enamel and caries-like lesions of enamel. Quintessence Int., v.19, p.773-85, 1988.

306 - SIMONSEN, R.J. The clinical effectiveness of a colored pit and fissure sealant at 24 months. Pediatr. Dent., v. 2, n.1, p.10-6, Mar. 1980.

307 - SIMONSEN, R.J. The clinical effectiveness of a colored pit and fissure sealant at 36 months. J. Amer. dent. Ass., v.102, p.232-7, 1981.

308 - SIMONSEN, R.J. Potential uses of a pit and fissure sealants in innovative ways: a review. J. Public HIth. Dent., v.42, n.4, p. 305-36, Fall 1982.

309 - SIMONSEN, R.J. Pit and fissure sealant individual patient care program. J. Dent. educ., v.48, n.2, p. 42-3, Feb. 1984.

310 - SIMONSEN, R.J. Retention and effectiveness of a single application of white sealant after 10 years. J. Amer. dent. Ass., v.115, p. 31-6, July 1987.

311 - SIMONSEN, R.J. Cost effectiveness of pit and fissure sealant at 10 year. Quintessence Int., v.20, n.2, p. 75-82, 1989.

312 - SIMONSEN, R.J. Criteria for placement and evaluation of pit and fissure sealant and preventive resin restorations. In: ANUSAVICE, K.J. Quality evaluation of dental restorations, Quintessence Books, 
1989. p.243-72.

313 - SIMONSEN, R.J. Retention and maintenance of fissure sealants over 10 years. J. Canad. Dent. Ass., v.56, n.3, p.253-7, Mar. 1990.

314 - SIMONSEN, R.J. New materials on the horizon. J. Amer. dent.Ass., v.122, p.25-31, 1991.

315 - SIMONSEN, R.J. Retention and effectiveness of dental sealant after 15 years. J. Amer. dent. Ass., v.122, p.34-42, 1991.

316 - SOUZA, M.M.; PITTA, A. Influência da profilaxia na permanência do se-lante. Avaliação clínica. Rev. gaúcha Odont., v.47, n.4, p.203-6, out./dez. 1999.

317 - STACH, D.J. et al. Change in occlusal height resulting from placement of pit and fissure sealants. J. prosth. Dent., v.68, p.750-3, 1992.

318 - STAMM, J.W. The use of fissure sealants in public health programs: a reactor's comments. J. Public HIth. Dent., v. 43, n.3, p. 243-6, Summer 1983.

319 - STAMM, J.W. Is there a need for dental sealants? Epidemiological indications in the 1980s. J. Dent. Educ., v.48, n.2, p.9-17, 1984.

320 - STAMM, J.W. Estudo de avaliação do risco de cárie na Universidade da Carolina do Norte: resultados finais e algumas abordagens experimentais alternativas. IN: BOWEN, W.H.; TABAK, L.A. Cariologia para a década de 90. São Paulo, Ed. Santos, 1995. p.209-233.

321 - STAMM, J.W; KATZ, R.V. Occlusal dental caries incidence and implications for sealants programs in a US college student population. J. Public HIth. Dent., v. 53, n.4, p.212-8, 1993.

322 - STEINMETZ, M.J. et al. Rechargeability of fluoride releasing pit and fissure sealants and restorative resin composites. Amer. J. Dent., v.10, n. 1, p.36-40, Feb. 1997.

323 - STEWART, D.J. Modified diamond instruments for the treatment of carious and pre-carious fissures. Brit. dent. J., v.106, n.20, p.73-6, Jan. 1959. 
324 - STRAFFON, L.H. Clinical evaluation comparing sealant and amalgam after 7 years: final report J. Amer. dent. Ass., v.117, n.6, p.751-5, Nov. 1988.

325 - STRAFFON, L.H. et al. Three-year evaluation of sealant: effect of isolation on efficacy. J.Amer.dent.Ass., v.110, p.714-17, May 1985.

326 - STRAND, G.V.; RAADAL, M. The efficiency of cleaning fissures with an airpolishing instrument. Acta. odont. scand., v.46, n.2, p.113-7, 1988.

327 - STRANG, R.; WHITTERS, C.J. Dental materials: 1996 literature review. Part 2.1. J. Dent., v.26, n.4, p.273-91, May 1998.

328 - STRANG, R. et al. Laboratory studies of visible-light cured fissure sealants: setting times and depth of polymerization. J. oral Rehab., v.13, p.305-10, 1986.

329 - SUNDFFELD, R. H. Análise microscópica da penetração "in vitro" de selantes de fóssulas e fissuras. Efeitos de tratamento superficiais e materiais. Araraquara, 1990. Tese (Doutorado)Faculdade de Odontologia de Araraquara, Universidade Estadual Paulista "Júlio de Mesquita Filho".

330 - SUNDFELD, R.H. et al. Análise clínica fotográfica da permanência de selantes de fossas e fissuras: 18 meses de análise. Rev. gaúcha Odont., v.38, n.3, p.388-94, 1991.

331 - SUNDFELD, R.H. et al. Permanência dos selantes: avaliação clínica foto-gráfica (18 meses de avaliação). Rev. gaúcha Odont., v.40, n.6, p.424-6, nov./dez. 1992.

332 - SUNDFELD, R. H. et al. Análise da permanência e penetração de um selante com flúor ( fluroshield). Rev. Ass. paul. Cirug. Dent., v. 48, n.1, p. 1251-5, jan./fev. 1994.

333 - SUNDFELD, R. H. et al. Avaliação clínica da permanência de um selante com flúor ( Fluroshield) - 18 meses de análise. Âmbito Odont., v.1, n. 27, p.5-8, jan./fev. 1996. 
334 - SUNDFELD, R.H. et al. Efeitos in vivo da profilaxia do esmalte dental na penetração de selantes de fóssulas e fissuras: estudo microscópico. Rev. bras. odont., v. 55, n.5, p.269-75, set./out. 1998.

335 - SVANBERG, M. et al. Mutans streptococci in interproximal plaque from amalgam and glass ionomer restorations. Caries Res., v.24, n.2, p.133-6, Mar./Apr. 1990.

336 - SWANGO, P.A.; BRUNELLE, J.A. Age and surface specific caries attach rates from the National Dental Caries Prevalence Survery. In: AMERICAN DENTAL ASSOCIATION for DENTAL RESEARCH. Abstracts. J. dent. Res., v.62, p.270, Mar. 1983. Abstract 909.

337 - SWIFT JUNIOR, E.J. The effect of sealants on dental caries: a review. J. Amer. dent. Ass., v.116, p.700-4, May 1988.

338 - SYRRIST, A. A seven year report on the effect of topical applications of sodium fluoride on dental caries. Odont. Rev., v.7, p.386-96, 1956.

339 - TAKAHASHI, Y. et al. The effect of sodium fluoride in acid etching solution on sealant bond and fluoride uptake. J. dent. Res., v. 59, n.3, p.625-30, Jan./Feb. 1980.

340 - TANAKA, M. et al. Incorporation into human enamel of fluoride slowly released from a sealant "in vivo". J.dent. Res., v.66, n.10, p.1591-3, Oct. 1987.

341 - TAVARES, S.S. et al. A permanência dos selantes- avaliação do grau de permanência de selantes de fóssulas e fissuras em três diferentes condições. Rev. gaúcha Odont., v.35 , n.2, p 91-4, mar./abr. 1987.

342 - TEN CATE, J.M. In vitro studies on the effects of fluoride on des and remineralization. J. dent. Res., v.69, p. 614-9, 1990.

343 - TERADA, R.S.S. et al. Avaliação in vitro da liberação de flúor de cimentos de ionômero de vidro e outros materiais que contém flúor. Rev. Odont. Univ. São Paulo, v.12, n.1, jan./mar. 1998. 
344 - THYLSTRUP, A. Tratado de Cariologia, Rio de Janeiro; Ed. Cultura Médica, 1988. 388 p.

345 - THYLSTRUP, A.; POULSEN, S. Retention and effectiveness of a chemically polymerized pit and fissure sealant after 2 years. Scand. J. dent. Res., v.86, p.21-4, 1978.

346 - TIBANA, M.M. et al. Influência do tipo de isolamento do campo operatório na retentividade de um selante de cicatrículas e fissuras. Rev. Odontoped., v.3, n.1, p.25-34, jan./mar. 1994.

347 - TILLIS, T.S. et al. Occlusal discrepancies after sealant therapy. J. prosthet. Dent., v.68, n.2, p. 223-8, July /Dec. 1992.

348 - TONN, E. M.; RYGE, G. Three year clinical evaluation of four sealants in Los Altos, CA. J. dent. Res., v. 61, p. 331, 1982.

349 - TOSTES, M.A. Prevenção de cáries de sulcos e fissuras em dentes permanentes com diferentes materiais contendo fluoretos. Rev. bras. Odont., v.54, n.6, p.368-71, nov./dez. 1997.

350 - TRUHE, T.F. Dental sealants. Prove safe and effective by 15 years of study, sealants, wich are specially beneficial for occusal surfaces, increase the likelihood that children will enter adulthood caries-free.

N.Y. State dent. J., v.52, n.2, p.25-7, Feb. 1991.

351 - TURPIN-MAIR, J.S.; RAWLS, H.R. Clinical study of a fluoride-releasing sealant in Jamaica children. J. dent. Res., v.71, n.1, p.631, 1992. Spec. Issue. Abstract 925.

352 - ULVESTAD, H. A 24-mont evaluation of fissure sealing with a diluted composite material. Scand. J. dent. Res., v.84, p. 51-5, 1976.

353 - VALSECKI, A.; VERTUAN, V. Permanência e eficácia do selante. Rev. gaúcha Odont., v.36, n.5, p.381-8, set./out. 1988.

354 - VAN DIJKEN, J. et al. Presence of Streptococcus mutans and lactobacilli in saliva and on enamel, glass ionomer cement, and composite resin surfaces. Scand. J. dent. Res., v.99, n.1, p.13-9, Feb. 1991. 
355 - VAN DORP, C.S.; TEN CATE, J.M. Preventive measures and caries progression: na in vitro study on fissures and smoth surfaces of humans molars. ASDC J. Dent. Child., v.4, n.59, p.257-62, July/Aug. 1992.

356 - VARSIO, S.; VEHKALAHTI, M. Dentist' decisions on caries risk and preventive treatment by dental state among 15-year-old adolescents. Community Dent. Health, v.14, p.166-70, 1997.

357 - VERTUAN, V.; MIRANDA, V.C. Importância de fluoretação das águas de abastecimento na redução da cárie dental. Rev. Fac. Farm. Odont. Araraquara, v. 9, p.157-66, 1975.

358 - VERTUAN, V.; BARELLI, N.; SERRA, M.C. Selantes de fóssulas e fissuras. Resultados de diferentes tempos de contaminação salivar na superfície do esmalte dental condicionado por ataque ácido: Estudo sob microscopia eletrônica de varredura. Rev. gaúcha Odont., v.36, n.6, p.421-5, nov./dez. 1988.

359 - VIEIRA, S.R. Avaliação da profundidade de penetração de selantes para fissuras e da incidência de cárie em fissuras clinicamente hígidas. Bauru, 1993 97p. Tese (Doutorado) - Faculdade de Odontologia de Bauru, Universidade de São Paulo.

360 - VILLELA, L.C. et al. Avaliação clínica de 24 meses do fluorshield e do vitremer utilizados como selantes de fossas e fissuras. Rev. odont. Univ. São Paulo, v.12, n.4, p.383-7, out/dez. 1998.

361 - VONO, B.G.; VONO, A.Z.; FIGUEIREDO, M.C. Técnica invasiva de selamento de fóssulas e fissuras: comparação entre selantes com carga e com flúor e ionômero de vidro. Rev. Fac. Odont. Bauru, v.4, n.3, p.9-16, jul./dez. 1996.

362 - VRBIC, V. Retention of fissure sealant and caries reduction. Quintessence Int., v.14, n.4, p. 421-4, Apr. 1983.

363 - VRBRIC, V. Five-year experience with fissure sealing. Quintessence Int., v.17, p. 371-2, 1986. 
364 - WAGGONER, W.F.; SIEGEL, M. Pit and fissure sealant application: updating the technique. J. Amer. dent. Ass., v. 127, p. 351-61, 1996.

365 - WALDMAN, H.B. Decreases in dental caries do not mean that children no longer need dental services. J. Dent. Child., v.57, p. 284-8, 1990.

366 - WEINTRAUB, J.A.; BURT, B.A. Prevention of dental caries the use of pit and fissure sealants. J. Public HIth. Policy, v.8, p. 542-60, 1987.

367 - WEINTRAUB, J.A. The effectiveness of pit and fissure sealants. J. Public HIth. Dent., v.49, n.5, p. 317-30, 1989. Special issue.

368 - WELLOCK, W.D.; BRUDEVOLD, F. A study of acidulated fluoride solutions. II-The caries inhibiting effect of single annual topical applications of and acid fluoride and phosphate solution: a two year experience. Arch. oral Biol., v.8, p.179-82, 1963.

369 - WENDT, L.; KOCK, G. Fissure sealants in permanent first molars after 10 years. Swed. dent. J., v.12, p.181-5, 1988.

370 - WEYNE, S. A construção do Paradigma de Promoção de saúde. In: KRIGER, L. Promoção de saúde bucal. São Paulo, Artes Médicas, 1997.

371 - WEYNE, S.; CEZAR, P.; GOMES, M. Selantes oclusais: avaliação de seu potencial na prevenção da cárie dentária e aspectos bacteriológicos. Rev. bras. Odont., v.34, n.1/2, p. 39-45, 1977.

372 - WHITEHURST, V.; SONI, N.N. Adhesive sealant clinical trial: results eithteen minuts after one application. J. Prevent. Dent., v.3, n.3, p. 20-2, May/June 1976.

373 - WILLIAMS, B.; VON FRAUNHOFER, J. A. The influence of the time of etching and washing on the bond strength of fissure sealants applied to enamel. J. oral Rehab., v.4, p.139-43, Mar. 1977.

374 - WILLIAMS, B.; WINTER, G.B. Fissure sealants. Further results at 4 years. Brit. dent. J., v.150, p. 183-7, 1981.

375 - WILLIAMS, B.; PRICE,R.; WINTER, G.B. Fissures sealants a two years clinical trial. Brit. dent. J., v.145, p. 329-64, 1978. 
376 - WILLIAMS, B.; VON FRAUNHOFER, J.A.; WINTER,G.B. Etching of enamel prior to application of fissure sealants. J. oral Rehab., v.3, p.185, 1976.

377 - WINKLER, M.M. et al. Using a resin-modified glass ionomer as an occlusal sealant: a one-vear clinical study. J. Amer. dent. Ass., v. 127, n. 10 p.1508-14, Oct. 1996.

378 -YAMAGA, Y. et al. Diamine silver fluoride and its clinical application. J. Osaka Univ. Dent. Sch., v.12, p.1-20, 1972.

379 - ZUANON, A.C.C.; SANTOS-PINTO, L.A.M.; CILENSE,M. Análise micros-cópica da penetração de um selante com carga em dentes decíduos em função do tempo de condicionamento ácido. Estudo in vitro. Rev. Odont. UNESP, v.24, n.2, p.385-93, 1995.

380 - ZUANON, A.C.C. et al. Comparação de cinco selantes oclusais quanto à permanência e eficácia na prevenção de cáries. Rev. Odont. UNESP, v.24, n.1, p.79-86, 1995. 
ABSTRACT 


\section{ABSTRACT}

\section{CLINICAL EVALUATION OF THE RETENTION OF SEALANT DEPENDING ON THE POSTERIOR APPLICATION OR NON-APPLICATION OF FLUORIDE AFTER SEALING.}

The purpose of this clinical study was to evaluate the retention of FLUROSHIELD sealant material (Caulk/ Dentsply, Milford) in first and second molars, depending on the posterior application or non-application of fluoride after sealing. Sixty molars without evidence of clinical or radiographic caries, respectively, were selected from 60 patients (age 8 -15 years) for this study. The molars were randomly divided into 2 experimental groups $(n=30)$ : Group A: the teeth were sealed, and afterwards received an application of topical fluoride gel. Group B: the teeth were only sealed. The retention of the sealant material was evaluated 4 times: baseline, 1-week, 6-months and 1-year. The differences in the retention between the groups were calculated for significance using a GOODMAN test. The results showed $100 \%$ retention for Groups $A$ and $B$ at the 1-week and 6-month evaluations. Only the 1-year evaluation showed a significant prevalence of retention for the group using fluoride gel. No occlusal/interproximal caries were found on the sealed teeth. It was concluded that the association of sealing and fluoride can increase the retention of the sealant FLUROSHIELD and also decrease the incidence of interproximal caries. 
APENDICE 


\section{APÊNDICE}

Apresenta-se a seguir, um modelo de correspondência, com a qual, o pesquisador comunica aos pacientes, data, hora e local onde serão realizados os procedimentos odontológicos a eles propostos através de exposição oral, dirimindo-lhes de imediato qualquer dúvida que surgissem a respeito do tratamento.

Senhores Pais:

da Clínica Acadêmica de Odontologia da Universidade do Sagrado Coração, vem por meio desta, pedir à V.S., uma autorização, para procedermos um tratamento odontológico, baseado na prevenção da cárie dentária a ser realizado no dia ....de 199....., às horas, en seus filhos juntamente com um planejamento para futuros controles.

Desde já, agradecemos. 